\title{
SPOŁECZNOŚCI KULTURY PÓŹNEJ CERAMIKI WSTĘGOWEJ CENTRALNEJ CZĘŚCI WYSOCZYZNY KUJAWSKIEJ
}

\author{
THE LATE BAND POTTERY CULTURE COMMUNITIES \\ IN THE CENTRAL KUJAVIA PLATEAU
}

\author{
Danuta Żurkiewicz \\ Instytut Prahistorii, Uniwersytet im. Adama Mickiewicza \\ ul. Św. Marcin 78, 61-809 Poznań, Poland
}

ABSTRACT. The paper discusses a structure of the settlement pattern of the Late Band Pottery culture - the Lengyel culture, Brześć Kujawski group, in a part of the Kujavia Plateau. In the first part, a microregional analysis of three selected sites is presented, in addition to discussing a special character of the associated artefacts. The second part focuses on the geography of settlement.

\section{WSTĘP}

Prezentowane opracowanie zawiera pełne zestawienie źródeł kultury późnej ceramiki wstęgowej na wydzielonym obszarze wschodniej części zlewni jeziora Gopło - rejon wnętrza Wysoczyzny Kujawskiej - dokumentuje je przestrzennie (geografia osadnictwa) oraz taksonomicznie. Praca otwiera nadto pole do interpretacji, sygnalizowanych wyżej danych, analizowanych w kategoriach funkcjonalno-gospodarczo-społecznych, czym wpisuje się w szerszy dyskurs zainicjowany w trakcie studiów porównawczych nad aglomeracjami ,późnowstęgowego” osadnictwa - „kruszańskiego” i „brzesko-kujawskiego". Cel niniejszej pracy można zatem zarysować dwustopniowo: jako dokumentację ogółu dostępnych danych dotyczących osadnictwa według określonych kategorii oraz weryfikację-testowanie uzyskanych w etapie pierwszym materiałów w stosunku do ustaleń z dziedziny geografii osadnictwa.

W pracy uwzględniono ogół źródeł pozyskanych w wyniku rozpoznania powierzchniowego, przeprowadzonego w ramach projektów: Atlasu Kujaw, Zespołu Badań Kujaw oraz Archeologicznego Zdjęcia Polski, jak też ratowniczych badań wykopaliskowych,

\footnotetext{
${ }^{1}$ Ostatnio Pyzel 2006.
} 
związanych z inwestycjami liniowymi w wewnętrznej strefie Wysoczyzny Kujawskiej. W niewielkim zakresie pulę informacji źródłowych wzbogacają efekty badań powierzchniowych autorki, prowadzone w rejonie Radziejowa, zorientowane na realizacje projektu dążącego do osadzenia obrazu osadnictwa na Wzgórzu Prokopiaka w kontekście osadniczo-gospodarczym doby środkowego i późnego neolitu. W ich efekcie liczba stanowisk, na których rozpoznano ślady bytności kultury późnej ceramiki wstęgowej, wzrosła z 18 punktów ujętych w syntezie L. Czerniaka z 1980 r., do 82 stanowisk, co w istotny sposób może wpłynąć na reinterpretację pozycji tego obszaru na mapie osadniczej omawianej jednostki kulturowej. Katalog źródeł ujmuje wykazy stanowisk z prac wcześniejszych ${ }^{2}$ oraz z kwerendy dostępnych archiwów: w delegaturach Wojewódzkich Urzędów Ochrony Zabytków w Bydgoszczy i we Włocławku, Archiwum Zakładu Prahistorii Polski w Instytucie Prahistorii UAM w Poznaniu oraz materiałów zgromadzonych w zasobach Fundacji Uniwersytetu im. Adama Mickiewicza w Poznaniu.

Graficznym udokumentowaniem powyższych zestawień jest mapa prezentująca dyspersję stanowisk ,późnowstęgowych” w ramach analizowanej przestrzeni, uwzględniająca zróżnicowanie funkcjonalne jako punkt wyjścia do analiz osadnictwa badanych społeczności. Pośród wszystkich zidentyfikowanych stanowisk 30 rozpoznano wykopaliskowo. Szczególne miejsce wśród nich zajmują: Chełmiczki 10, Olszewice 7, Karczyn 21/22, określone mianem obiektów diagnostycznych, podlegających szczegółowej specyfikacji pozyskanych $\mathrm{w}$ ich obrębie materiałów.

Przez pojęcie „kultura późnej ceramiki wstęgowej” (,późnowstęgowa”, w skrócie KPCW) używane w tej pracy rozumiem łączne ujęcie dwóch odmiennych stanów rozwojowych społeczności postlinearnych: faza I odpowiada na ziemiach polskich pojęciu kultury ceramiki wstęgowej kłutej, kultury wczesnolendzielskiej oraz wczesnopolgarskiej; natomiast fazy II-III są równoznaczne pojęciu grupy brzesko-kujawskiej kultury lendzielskiej ${ }^{3}$.

Przyjęty zakres chronologiczny rozpatrywanego taksonu został zdefiniowany przez L. Czerniaka ${ }^{4}$ i w pracy tej podlega częściowej modyfikacji w konfrontacji z najnowszymi wynikami datowania względnego omawianego taksonu ${ }^{5}$. W ramach chronologii bezwzględnej mieści się on $\mathrm{w}$ przedziale: faza $\mathrm{I}-\mathrm{IIa}=4850-4500 / 4400$ cal $\mathrm{BC}^{6}$ oraz fazy IIb-III = 4500/4400-3900/3800 cal BC.

Zakres przestrzenny pracy obejmuje wschodnią część zlewni ieziora Gopło oraz fragment Kanału Parchańskiego należący już do zlewni rzeki Wisły ${ }^{7}$. Teren ów administracyjnie należy do powiatów: radziejowskiego, inowrocławskiego i aleksandrowskiego. Ścisłą granicę prezentowanego obszaru wytyczono arbitralnie na podstawie sieci arku-

\footnotetext{
${ }^{2}$ Czerniak 1980, Katalog II, 1994, s. 150-155; Pyzel 2006, tab. III, IV.

${ }^{3}$ Czerniak 1994, s. 3.

${ }^{4}$ Czerniak 1994, s. 34

${ }^{5}$ Grygiel 2008, s.2032 (daty dla grupy brzesko-kujawskiej kultury lendzielskiej).

${ }^{6}$ Kalibracja według Pearson et a1. 1986.

${ }^{7}$ Na podstawie Czarneckiej 2005.
} 
szy AZP. Zainteresowania moje dotyczyły 25 arkuszy o łącznej powierzchni ok. 937 km². Teren ów delimituje zwartą przestrzeń w ramach „centralnej” ekumeny „późnowstęgowej”, zlokalizowaną między jej aglomeracjami w rejonie Brześcia Kujawskiego (Kujawy Wschodnie - wschodnia część Wysoczyzny Kujawskiej) i Kruszy Zamkowej (Kujawy Zachodnie - zachodnia część Wysoczyzny Kujawskiej) ${ }^{8}$.

Do chwili zakończenia kompletowania źródeł zamieszczonych w Katalogu (październik 2010), w obrębie dwóch z rozpatrywanych arkuszy nie dokonano rozpoznania powierzchniowego w ramach akcji AZP. Jednak rozważana przestrzeń w całości wcześniej podlegała prospekcji powierzchniowej w ramach projektu Atlasu Kujaw, realizowanego przez Zespół Badań Kujaw. Do wymienionych wcześniej przedsięwzięć należy dołączyć również rekonesans konserwatorski poprzedzający budowę inwestycji liniowych.

Pulę informacji źródłowych uzupełniają wyniki prac wykopaliskowych Ekspedycji Kujawskiej i Zespół Badań Kujaw oraz wyniki badań ratowniczych prowadzonych wzdłuż Petrociągu i Gazociągu Mogilno - Włocławek. Podstawą do wyróżnienia stanowisk KPCW była ceramika oraz odnotowanie paciorków wykonanych z muszli spondylus, a także charakterystycznego fragmentu miedzianego naszyjnika.

W dotychczasowej historii badań interesującej nas problematyki należy odnotować dwa zakresy - nurty studiów. Pierwszy dotyczy zabiegów porządkujących związanych $\mathrm{z}$ omawianym taksonem. $\mathrm{W}$ tej dziedzinie wspomnieć należy prace K. Jażdżewskiego ${ }^{9}$ i L. Gabałówny ${ }^{10}$, które opierają się na materiałach z Brześcia Kujawskiego i określają kilka cech taksonomicznych badanej jednostki. Zakres drugi dotyczy zagadnień osadniczo-gospodarczych i społecznych. Temat ten zarysowany został w pracy L. Czerniaka i J. Piontka ${ }^{11}$, inicjując fascynującą polemikę nad fenomenem ,niżowego modelu kultur późnowstęgowych". Z racji rangi rzeczonego zagadnienia oraz wieloetapowego przebiegu, dyskusja ta znajdzie nieco bardziej szczegółowe omówienie w rozdziale 1, dotyczącym historii badań nad kujawską enklawą kultury późnej ceramiki wstęgowej. W tym miejscu pragnę jedynie wykazać zasadność ponownego podjęcia omówionej już w przeszłości tematyki. Powód ten można sprowadzić do zakresu chorologicznego prezentowanej pracy. $Z$ punktu widzenia wcześniejszych badań nad osadnictwem kultury późnej ceramiki wstęgowej, teren Kujaw Czarnych Radziejowskich stanowi obszar wyraźnej jego dekoncentracji, między skrajnymi punktami, charakteryzującymi się większą zwartością zasiedlenia, wyznaczającymi zarazem rubieże ekumeny „późnowstęgowej”" ${ }^{12}$.

W pracy zastosowano zestaw metod opisanych i wykorzystanych już wcześniej w dorobku wielu autorów. Dotyczy to przede wszystkim metod analizy typologiczno-

\footnotetext{
${ }^{8}$ Czerniak 1980.

${ }^{9}$ Jażdżewski 1938.

${ }^{10}$ Gabałówna 1966.

${ }^{11}$ Czerniak, Piontek 1979.

${ }^{12}$ Za takie punkty można uznać okolice Kruszy Zamkowej i Jeziora Pakoskiego na zachodzie i Brześcia Kujawskiego na wschodzie kujawskiej ekumeny „późnowstęgowej”- Czerniak 1980, mapa 3.
} 
-chronologicznej opracowane przez L. Czerniaka ${ }^{13}$. W zakresie badań z dziedziny geografii osadnictwa główne inspiracje metodycznie zawarte są w pracach A. Pelisiaka ${ }^{14}$ i J. Pyzel ${ }^{15}$. Procedury analizy gospodarczo-społecznej, stosowane podczas realizacji drugiego etapu osiągnięcia zarysowanego celu, sprecyzowane zostały przez J. Kruka ${ }^{16}$ i J. Pyzel.

\section{HISTORIA BADAŃ NAD KUJAWSKĄ ENKLAWĄ KULTURY PÓŹNEJ CERAMIKI WSTĘGOWEJ}

Przystępując do rozważań nad historią badań kujawskiej enklawy „późnowstęgowej”, należy mieć na uwadze dwustopniowy zakres celu prezentowanej pracy. Poziom pierwszy (a) dotyczy zabiegów analitycznych zmierzających do wyodrębnienia cech definiujących ramy odrębności taksonomicznej omawianej jednostki. Rozważania prowadzone na poziomie etapu drugiego (b) dotyczą tematyki gospodarczo-społecznej KPCW. Poniższy rozdział został więc podzielony na dwie prezentacje historii badań: taksonomiczną oraz gospodarczo-społeczną.

\subsection{Perspektywa taksonomiczna}

Pierwszym znaczącym głosem zarysowującym interesującą nas problematykę była praca K. Jażdżewskiego ${ }^{17}$ zawierająca klasyfikacje materiałów „wstęgowych” ze stanowiska w Brześciu Kujawskim. Obok znanych już ówcześnie kultur z cyklu wstęgowego (ceramiki wstęgowej rytej i kreskowokłutej), autor wydzielił nową kulturę: brzesko-kujawską, zaliczając do niej część materiałów z eponimicznego stanowiska oraz kilka dalszych „znalezisk” z Kujaw. Odrębność rzeczonego taksonu od innych jednostek „wstęgowych” mieściła się m.in. w charakterystycznym i konsekwentnie przestrzeganym obrządku pogrzebowym, ceramice odznaczającej się zanikiem bogatej ornamentyki i „nieszlamowaniem” gliny oraz karbowaniem krawędzi naczyń. Do cech diagnostycznych zaliczał K. Jażdżewski także wyroby miedziane o analogiach południowych, topory rogowe, naramienniki kościane, ozdoby z muszli oraz domy trapezowate. Opierając się na obserwacjach stratygraficznych z Brześcia Kujawskiego i na analogiach z innych obszarów, K. Jażdżewski synchronizował moment przybycia społeczności kultury brzesko-kujawskiej na teren Niżu z młodszą fazą kultury ceramiki wstęgowej rytej (KCWR). Wnioskował on również o całkowitej lub częściowej jej współczesności z grupami połu-

\footnotetext{
${ }^{13}$ Czerniak 1980.

${ }^{14}$ Pelisiak 2003.

${ }^{15}$ Pyzel 2006.

${ }^{16}$ Kruk 1980.

${ }^{17}$ Jażdżewski 1938.
} 
dniową i północną kultury kreskowokłutej, kulturą jordanowską, kulturą morawskiej ceramiki malowanej oraz starszą fazą kultury pucharów lejkowatych (KPL).

Swoją wypowiedź na temat interesującej nas jednostki K. Jażdżewski skorygował w 1965 r. ${ }^{18}$ poprzez rezygnację z klasyfikacji „kulturowej” omawianego zjawiska, motywując stosowanie terminu ,grupa brzesko-kujawska kultury lendzielskiej” jako lepiej akcentujące jej związki z kręgiem naddunajskim ${ }^{19}$.

W roku 1966 J. K. Kozłowski, klasyfikując źródła należące do kultur lendzielskiej i polgarskiej z obszarów Małopolski, przyporządkował materiały grupy brzesko-kujawskiej do drugiego i trzeciego horyzontu chronologicznego, synchronizując je ze starszą i młodszą fazą górnośląskiej grupy ocickiej.

Inna perspektywa ujęcia omawianego taksonu została zaproponowana przez środowisko Zespołu Badań Kujaw uformowane wokół Instytutu Prahistorii UAM w cyklu prac „Ze studiów nad rozwojem kultur wstęgowych na Kujawach”, gdzie obok publikacji nowych materiałów znalazły się rozważania nad genezą oraz próby wewnętrznej periodyzacji omawianej jednostki.

Pierwszy ze wzmiankowanego powyżej cyklu opracowań artykuł pióra J. Bednarczyka, Aleksandra Kośko, E. Krausego ${ }^{20}$ dotyczył klasyfikacji materiałów „wstęgowych" znad Jeziora Pakoskiego. Zwrócono wówczas uwagę na możliwość lepszego poznania systematyki ceramiki, poprzez zastosowanie systemowych zasad analizy technologii i zdobnictwa. Zaleta tej metody to możliwości aplikacji kryteriów jakościowoilościowych. Wykorzystując specyfikacje cech różnicujących oraz określając relację tych parametrów wyodrębniono sześć grup technologicznych ${ }^{21}$. Analiza zdobnictwa oparta została na liście cech specyfikujących występujących w relacji do osi symetrii naczynia i cech technoformalnych ornamentyki. Korelacja parametrów technologicznych, zdobnictwa i morfologii pozwoliła na wydzielenie czterech faz rozwojowych ugrupowań „późnolendzielskich” znad Jeziora Pakoskiego.

Rozwinięcie założeń zawartych w omówionym wyżej studium stanowi opracowanie materiałów „wstęgowych” ze stan. 5 w Inowrocławiu - Mątwach ${ }^{22}$. Autorzy skupili się wokół zespołów z „ceramiką kłutą”, której schemat klasyfikacji, oparty na materiałach czeskich $^{23}$, okazał się mało efektywny, w związku z czym nie mógł stać się podstawą ścisłego datowania ani wyznacznikiem dynamiki przemian w całym zasięgu występowania tego typu zdobień. Postulowano indywidualne podejście do materiałów z poszczególnych stref regionalnych. Efektem realizacji tego postulatu było utworzenie trój-

\footnotetext{
${ }^{18}$ Kostrzewski, Chmielewski, Jażdżewski 1965.

${ }^{19}$ Gabałówna 1966, s. 11 i przyp. 9.

${ }^{20}$ Bednarczyk, Kośko, Krause 1979.

${ }^{21}$ Grupy od F do K - w nawiązaniu do grup utworzonych przez Gabałównę (1963) odnośnie do ceramiki KCWR.

${ }^{22}$ Czerniak, Kośko 1980a.

${ }^{23}$ Zápotocka 1970
} 
fazowej - kujawskiej systematyki rozwoju stylistycznego ceramiki „późnowstęgowej”24. Podział uzasadniono diagnostyką technologii i stylistyki według kryteriów zaproponowanych we wcześniejszej pracy. Rozpatrując przykład zespołu z ceramiką kłutą ze stanowiska Poznań-Dębiec, autorzy doszli do wniosku, iż tworzył on zbiór wielorodny, złożony genetycznie, wyznaczający początek horyzontu „późnolendzielskiego”: załamania się ogólnowstęgowego modelu kultury i stopniowego kształtowania struktury określanej już wcześniej jako niżowy model kultury wstęgowej ${ }^{25}$. Okres ten charakteryzował się osłabieniem więzi z Południem oraz włączeniem ugrupowań późnolendzielskich w układ lokalnych zależności, sięgających okresu mezolitu, w ramach tzw. strefy wielkodolinnej Niżu ${ }^{26}$. Wyraźne zaznaczenie odrębności lokalnej, niżowej specyfiki omawianej jednostki, w procesie autogenezy, zostało zaakcentowane poprzez nadanie jej nowej nazwy: kultura późnej ceramiki wstęgowej ${ }^{27}$.

Próbą zamknięcia pewnego etapu badań nad społecznościami wstęgowymi z obszaru Kujaw jest praca L. Czerniaka: Rozwój społeczeństw kultury późnej ceramiki wstęgowej na Kujawach ${ }^{28}$. Publikacja w sposób kompleksowy przedstawiła problem taksonomii typologiczno-chronologicznej materiałów KPCW. Na podstawie klasyfikacji cech ceramiki ${ }^{29}$ wydzielone zostały trzy fazy rozwoju z podfazami: faza I-IIa KPCW $=$ w dotychczasowym ujęciu kultura ceramiki wstęgowej kłutej (KCWK) oraz fazy IIb-III KPCW = określane wcześniej grupą brzesko-kujawską kultury lendzielskiej. Zdecydowany sprzeciw wobec propozycji badaczy poznańskich podniósł R. Grygiel, który traktuje omawiany takson jako grupę kultury lendzielskiej ${ }^{30}$.

Odmienne perspektywy ujęcia taksonu, zawierające się w propozycji stosowania terminu ,grupa brzesko-kujawska” K. Jażdżewskiego i kontrpropozycji - KPCW, wynikają z innych koncepcji genezy, co rzutowało na stosowaną terminologię i na chronologię omawianej jednostki. W prowadzonej dyskusji wyróżnić można kilka kwestii, wokół których skupia się dyskurs.

\subsubsection{Problem hiatusu}

Istotne wydaje się nadal zagadnienie hiatusu, który rysuje się na Kujawach po zaniku tamtejszych społeczności KCWR. L. Czerniak $(1980 ; 1994)$ thumaczył to zjawisko

\footnotetext{
${ }^{24}$ Faza 1 - stylistyka konarsko-malicka; faza 2 - stylistyka Inowrocław - Mątwy 5; faza 3 - stylistyka kościelecko-modlnicka.

${ }^{25}$ Bednarczyk, Kośko, Krause 1979.

${ }^{26}$ Przemawia za tym obecność cech rösseńskich, niżowy typ surowcowo-technologiczny profilu krzemieniarstwa.

${ }^{27}$ Bednarczyk, Czerniak, Kośko 1980.

${ }^{28}$ Czerniak 1980.

${ }^{29}$ Według modelu stosowanego w pracy Czerniaka, Kośko 1980 b.

${ }^{30}$ Grygiel 2008.
} 
istniejącym stanem badań, wyrażając pogląd o „wypełnieniu luk” w przyszłości. Uważał, iż społeczności KCWR zaludniły Kujawy w stopniu, w którym kolejne zmiany kulturowe nie mogły zachodzić bez udziału tego czynnika. Zdaniem tego autora (1996a, s. 74): ,istnienie luki KCWR - KPCW można ewentualnie kiedyś obalić, ale nigdy potwierdzić". Argumenty stosowane w tej dyskusji powinny wykraczać poza przesłanki taksonomiczne, opierając się na danych z dziedziny geografii osadnictwa.

Inną interpretację nieciągłości osadniczej przedstawił J. K. Kozłowski (1988). Jego zdaniem kujawska KCWR w ostatniej fazie swojego rozwoju wykazywała tendencję zanikową, ilustrowaną przez małą ilość materiałów ,żeliezowskich”, co przekładało się na osłabienie kontaktów z Małopolską. Efektem tego była izolacja kujawskiej społeczności KCWR, która mogła prowadzić do wytworzenia się niżowego modelu neolitu (KPL). Podkreślając rolę zjawiska hiatusu obserwowanego na Kujawach między KCWR a społecznościami późniejszymi, autor wnioskował o allochtonicznym pochodzeniu nowych jednostek, niewywodzących się bezpośrednio z kręgu „wstęgowego”, co przemawiało za nieprawidłowym sformułowaniem nazwy KPCW.

Do poglądów J. K. Kozłowskiego odnośnie do dyskontynuacji kujawskiego osadnictwa „wstęgowego" na poziomie wczesnego i środkowego neolitu nawiązywał R. Grygiel. W ujęciu tego autora niżowe populacje KCWR, w końcowej fazie swojego rozwoju, na skutek pogarszających się warunków klimatycznych (gwałtownego osuszenia się klimatu), zostały zmuszone do emigracji w kierunku południowo-zachodnim i zachodnim, w tym w dorzecze Łaby, Odry i Solawy, a ugrupowania późniejsze związane są z przybyciem nowych fal - reemigracją osadników z południowego zachodu ${ }^{31}$; przy czym: ,[...] tamtejsze społeczeństwa w ograniczonym zakresie mogły zachowywać kontrolę nad opuszczonymi terenami do czasu gdy warunki środowiska obszaru Niżu Polskiego ponownie wróciły do stanu równowagi"32. Za koncepcją L. Czerniaka wywodzącą KPCW z KCWR opowiedziała się natomiast J. Pyzel ${ }^{33}$, stwierdzając duże podobieństwo obu kultur pod względem gospodarczym i społecznym. Możliwości lepszego poznania genetycznego wynikania obu kultur widzi ona w dalszych studiach osadniczych. Za wzorcowy przykład słuszności tego argumentu podaje obserwacje stratygraficzne ze stanowiska 22/23 w Bożejewicach ${ }^{34}$.

\subsubsection{Koncepcje genezy}

Pierwszą próbę wyjaśnienia genezy grupy brzesko-kujawskiej podjął K. Jażdżew$\mathrm{ski}^{35}$, który sytuował ją w kręgu kultury lendzielskiej. Autor ten przyjmował możliwość

\footnotetext{
${ }^{31}$ Osadnicy ci mieli bybyć przedstawicielami KCWK fazy III/IV, a proces ten to „powrót starych emigrantów"; Grygiel 2004, 2008.

${ }^{32}$ Grygiel 2009 s. 1991.

${ }^{33}$ Pyzel 2006b.

${ }^{34}$ Chata KPCW II - III nakłada się tutaj na dom KCWR z fazy IIA (Czerniak 1998).

${ }^{35}$ Jażdżewski 1965; 1983.
} 
częściowej współczesności późnej fazy KCWR z wczesnym okresem wymienionej grupy, jednak nie wiązał z nią genezy tej jednostki. W pracy z 1958 dotyczącej KCWK w Polsce M. Steklá-Zápotocka wskazuje na powiązania genetyczne grupy brzesko-kujawskiej z tym taksonem, wiążąc jej początek z V fazą KCWK.

Nowa koncepcja powstania „niżowego modelu wstęgowego”, zarysowana wcześniej w tym rozdziale, ostatecznie zaprezentowana przez L. Czerniaka ${ }^{36}$, zakładała, iż podstawowym składnikiem dokonującej się transformacji były społeczności KCWR, które stojąc w obliczu kryzysu ekologicznego, musiały przystosować się do nowych warunków środowiska. Przekształceniu temu towarzyszyły wpływy (także migracje) z ośrodków południowych. Obecność starego substratu w formowaniu nowej struktury została zaakcentowana w nazwie tej jednostki ${ }^{37}$.

Sprzeciw wobec stosowania nazwy KPCW, a co za tym idzie uznania jej kontynuatywności w kwestii genezy, wniósł J. K. Kozłowski ${ }^{38}$. Dostrzegł on złożoność środkowego neolitu na Niżu, zwrócił uwagę na znaczenie postlinearnej kultury malickiej, w procesie formowania się nowych taksonów obszaru Kujaw. To na jej podłożu, wraz z elementami „postkłutymi” i ,,rösseńskimi” miała powstać odrębna jednostka kulturowa (fazy I-IIa KPCW), która z kolei stanowiła podstawę rozwoju grupy brzesko-kujawskiej odpowiadającej fazom IIb-IIIc KPCW.

Spotęgowanie znaczenia kultury malickiej $\mathrm{w}$ tak zwanej drugiej fazie neolityzacji Niżu miała na celu prezentacja przez R. Grygla ${ }^{39}$ materiałów z Gustorzyna, stan. 1. Odczytał on w nich cechy pochodzące wprost $\mathrm{z}$ kultury malickiej z udziałem wątków „poströsseńskich”, które łącznie z materiałami o cechach „pleszewskich”, ze stan. 4 w Brześciu Kujawskim tworzyły specyfikę grupy brzesko-kujawskiej, zaliczanej przez tego badacza do kręgu lendzielsko-polgarskiego. Wkład kultury malickiej w powstanie grupy brzesko-kujawskiej autor utożsamiał z wpływami polgarskimi. Na zmianę poglądów R. Grygla miała wpływ reinterpretacja przynależności kulturowej konstrukcji trapezowatej z Niedźwiedza, co w istotny sposób miało osłabić wymowę materiałów kujawskich zaliczonych wcześniej do kultury malickiej.

W dyskusji nad klasyfikacją taksonu po raz kolejny zabrał głos L. Czerniak ${ }^{40}$. Stwierdził, że ujęcie R. Grygla traktuje tę jednostkę w kategoriach kopii ugrupowań południowych; natomiast nie akcentuje, że obok wpływów małopolskich widoczne są też elementy odrzańsko-łabskie uformowane na podstawie KCWK oraz zestaw cech lokalnych - niżowych. Nazwa proponowana przez R. Grygla okazała się niezgodna z klasyfikacją genetyczną oraz statusem jednostki, która wymykała się pojęciom stwo-

\footnotetext{
${ }^{36}$ Czerniak 1980.

${ }^{37} \mathrm{~W}$ prezentowanym ujęciu cykl wstęgowy - kultura ceramiki wstęgowej jest podzielony na KCW wczesną (KCWR) i późną (KPCW).

${ }^{38}$ Kozłowski 1988.

${ }^{39}$ Grygiel 1996.

${ }^{40}$ Czerniak 1996b.
} 
rzonym dla ugrupowań wokółkarpackich; powinna zatem być potraktowana jako odrębna jednostka kulturowa.

Poszukiwaniem pewnego konsensusu w kwestii nazewnictwa była propozycja L. Czerniaka co do powrotu do określenia wprowadzonego przez K. Jażdżewskiego kultura brzesko-kujawska, ale z zaliczeniem do niej także materiałów „kłutych” z fazy I KPCW. Znaczący w tej dyskusji wydaje się głos J. Pavúka ${ }^{41}$, który w sposób jednoznaczny klasyfikuje grupę brzesko-kujawska, jako autonomiczny takson niezwiązany genetycznie z kulturą lendzielską.

Polemikę z taką prezentacją poruszanej tu tematyki po raz kolejny podjął R. Grygiel $^{42}$. Według jego najnowszego ujęcia geneza grupy brzesko-kujawskiej kultury lendzielskiej związana jest $\mathrm{z}$ bezpośrednią migracją ludności KCWK $\mathrm{z}$ dorzecza Odry, szczególnie z terenu Śląska oraz strefy środkowoodrzańskiej, przez którą docierały społeczności z dorzecza Łaby i Solawy. Podłożem dla wykształcenia się grupy brzeskokujawskiej były późne społeczności KCWK przybyłe na Niż Polski z dorzecza Odry oraz terenów solawsko-nadłabskich. Proces ten nazywany przez autora „wielką migracją późnej KCWK" rozpoczął się najwcześniej w fazie IVa (według M. Zápotockiej), rosnący wpływ czynników pochodzenia rösseńskiego i lendzielskiego, połączony z koncentracją osadnictwa na obszarze Kujaw, Pałuk oraz ziemi chełmińskiej doprowadził do wykształcenia grupy brzesko-kujawskiej kultury lendzielskiej. W ujęciu tym autor całkowicie eliminuje z genezy tych społeczności czynniki pochodzenia małopolskiego.

\subsection{Tematyka gospodarczo-społeczna $\mathrm{z}$ perspektywy historii badań}

Przechodząc do omówienia nurtu studiów gospodarczo-społecznego związanego z KPCW, zacznę od pracy K. Jażdżewskiego z $1965 \mathrm{r}^{43}$, gdzie znajdujemy interpretację faktu wielokrotnego przecinania się zarysów chat trapezowatych, będącego zdaniem autora, ilustracją mechanizmów związanych z funkcjonowaniem gospodarki. Uważał on, że stosowanie upraw ekstensywnych zmuszało mieszkańców do przenoszenia się po kilku lub kilkunastu latach do nowo założonej osady, a powrót na miejsce poprzednio zajęte był możliwy, gdy spalenie wyrosłych na polu roślin gwarantowało wzrost żyzności gleby. Powstał w ten sposób zarys rotacyjnego modelu funkcjonowania osadnictwa, zależnego od gospodarki.

Kontynuacji rozpoczętej przez K. Jażdżewskiego publikacji materiałów z Brześcia Kujawskiego podjęła się L. Gabałówna ${ }^{44}$. Jej praca bazująca głównie na źródłach osadowych dążyła do rekonstrukcji faz zabudowy osiedla. Autorka, analizując powiązania

\footnotetext{
${ }^{41}$ Pavúk 2007, s. 20.

${ }^{42}$ Grygiel 2008.

${ }^{43}$ Kostrzewski, Chmielewski, Jażdżewski 1965.

${ }^{44}$ Gabałówna 1966.
} 
stratygraficzne nawarstwiających się domów, doszła do odmiennej ich interpretacji w stosunku do konkluzji K. Jażdżewskiego. Ustaliła, iż osady były zamieszkiwane na stałe. Powołała się na dane z dziedziny gospodarki i gleboznawstwa, interpretując osady jako przejaw zasiedziałości, a nie cyklicznych powrotów na to samo miejsce. Potwierdzeniem tej tezy był też jednolity materiał ceramiczny, który pojawił się w Brześciu Kujawskim jako zespół ukształtowanych już form kontynuowanych w sposób zasadniczo niezmieniony przez cały okres funkcjonowania osady.

Rozważając związek form osadnictwa z gospodarką, T. Wiślański ${ }^{45}$ przychylił się do rozwiązania zaproponowanego przez K. Jażdżewskiego. Zjawisko występowania przecinających się faz zabudowy zinterpretował on jako efekt cyklicznego opuszczania osady po wyjałowieniu gleb. Zasięg i częstotliwość takiej wędrówki miały zależeć od stopnia rozwoju danej grupy i lokalnych warunków środowiska. Poprzez identyfikację obszarów o szczególnie dogodnych warunkach miały powstać regiony osadnicze o bardziej trwałym charakterze. W tym ujęciu centrum gospodarki stanowiła osada centralna otoczona kompleksem pól i ogrodów. Nierównomierne jałowienie gleb prowadziło do powiększenia obszaru intensywnej eksploatacji i utworzenia sezonowych osad pomocniczych. Po pewnym czasie następowało zakłócenie równowagi ekologicznej mikroregionu, co zmuszało mieszkańców do przeniesienia osady centralnej w inne miejsce, często opuszczone już w przeszłości, odznaczające się mniejszym stopniem zalesienia.

Zarys głównych cech rozwoju gospodarki ,późnowstęgowej” został zaprezentowany w publikacji materiałów „lendzielskich” znad Jeziora Pakoskiego ${ }^{46}$. W tym zakresie wyodrębniono dwa etapy przedstawiające pojawienie się nowej struktury chowu zwierząt, ograniczonej przestrzennie do Kujaw Zachodnich. Innowacyjna konstrukcja gospodarcza miała determinować charakter osadnictwa, które na przełomie fazy pierwszej i drugiej nabrało cech większej stabilności. Suma prezentowanych wyróżników (stylistyka, technologia ceramiki, gospodarka) przedstawiała moment tworzenia się, synkretycznego w aspekcie genetycznym, ,niżowego modelu kultury „późnowstęgowej”.

Nawiązaniem do tezy T. Wiślańskiego była próba modelowego opisu form organizacji gospodarczej oraz społecznej KPCW autorstwa L. Czerniaka i J. Piontka ${ }^{47}$. Badacze ci, analizując szereg danych z dziedziny ekologii populacyjnej oraz zmiennych kulturowych, odrzucili hipotezę o stałym zasiedleniu osad typu Brześć Kujawski. Przeprowadzona analiza uprawomocniła natomiast tezę o rotacyjnym charakterze „późnowstęgowego" systemu osadniczego.

W komentowanym już wcześniej studium L. Czerniak ${ }^{48}$ wiele miejsca poświęcił tematyce gospodarczo-społecznej. Operując pojęciami potencjału demograficznego i pojemnością środowiska, autor wnioskował o załamaniu się systemu kulturowego u schył-

\footnotetext{
${ }^{45}$ Wiślański 1969.

${ }^{46}$ Bednarczyk, Kośko, Krause 1979.

${ }^{47}$ Czerniak, Piontek 1979.

${ }^{48}$ Czerniak 1980.
} 
ku rozwoju społeczeństw „wczesnowstęgowych” (KCWR), co wymuszało proces transformacji systemu gospodarczego (fazy I-IIa KPCW) w kierunku intensyfikacji metod eksploatacji środowiska oraz poszerzenia ekumeny przez migracje. W kolejnym etapie (fazy IIb-III KPCW) dochodzi do stabilizacji nowopowstałego systemu na podstawie rotacyjnego modelu gospodarczo-społecznego, zorganizowanego w obrębie układu mikroregionów osadniczych.

Odmienny pogląd na zagadnienie funkcjonowania systemu społeczno-gospodarczego wyraził R. Grygiel $^{49}$. Autor, opierając się na efektach badań w Brześciu Kujawskim, przychylił się do poglądów L. Gabałówny ${ }^{50}$ odnośnie do nieprzerwanego zasiedlenia jednego z domostw, które wraz z przyległymi obiektami gospodarczymi użytkowano przez okres około 200 lat. Ten odcinek czasu dotyczy dwóch, powiązanych stratygraficznie konstrukcji badanej chaty trapezowatej. Potwierdzeniem stałości zasiedlenia było datowanie ${ }^{14} \mathrm{C}$ uzyskane $\mathrm{z}$ dwóch etapów użytkowania chaty. Dodatkowym argumentem wspierającym uzyskane datowanie ${ }^{14} \mathrm{C}$ była efektywność gospodarcza związana z czasem użytkowania takiej budowli w stosunku do bardzo dużego nakładu pracy poniesionego przy jej wznoszeniu. W ujęciu tym organizacja społeczno-gospodarcza opierała się na dużych osadach centralnych, które rozrastając się wraz z liczbą jej mieszkańców generować, miały powstanie osad mniejszych, o charakterze pomocniczym względem osad centralnych. Jednolita organizacja społeczeństw grupy brzesko-kujawskiej przejawiała się w zwartym układzie cech kultury materialnej widocznych m.in. w podobnych formach zdobnictwa ceramiki, regułach budownictwa czy wytworach miedzianych.

Wiele interesujących spostrzeżeń odnośnie do tematyki gospodarczo-społecznej omawianych społeczności wnosi najnowsza rozprawa R. Grygla ${ }^{51}$. Autor, analizując system gospodarczy społeczności „późnowstęgowych”, wydziela jego dwa stopnie: 1 - fazę taktyki osadniczej ${ }^{52}$ oraz 2 - etap strategii osadniczej. Pierwszy z wymienionych przedziałów obejmuje okres wielkiej migracji późnej KCWK na teren Niżu Polski; dotyczy ona pojedynczych grup składających się z dwóch - trzech rodzin, które zakładając niewielkie osady, przełamują wszelkie bariery środowiskowe, zasiedlając rozległą ekumenę po Zatokę Gdańską i okolice Starogardu Gdańskiego. Około 4600 p.n.e. obserwujemy wycofywanie się osadnictwa KCWK z części Niżu m.in. z dorzecza dolnej Wisły i jego koncentrację na obszarze Kujaw, Pałuk i ziemi chełmińskiej. Szybki wzrost demograficzny w wyżej wymienionych rejonach oraz napływ społeczności przynoszących wzorce lendzielskie i rösseńskie miał decydujący wpływ na genezę grupy brzesko-kujawskiej, która reprezentować ma etap strategii osadniczej. Organizacja społeczno-gospodarcza oparta była na systemie osad centralnych, których zaplecze gospodarcze stanowiły podporządkowane im osady satelickie. Szereg danych pochodzących z prac

\footnotetext{
${ }^{49}$ Grygiel 1986.

${ }^{50}$ Gabałówna 1966.

${ }^{51}$ Grygiel 2008.

${ }^{52}$ Bogucki 1979.
} 
wykopaliskowych w rejonie Brześcia Kujawskiego i Osłonek pozwala autorowi na wnioskowanie o różnicach społecznych (elity, wojownicy, podporządkowane odrębne etnicznie populacje) oraz o wynikających z tego konfliktach społecznych i ich wpływie na rozwój osadnictwa (fortyfikacje Osłonek)

Rozpatrując tematykę gospodarczo-społeczną, zauważalny jest jej dychotomiczny charakter. Odnośnie do tego samego przedziału chronologicznego rozróżniamy jej rotacyjny $^{53}$ lub stały ${ }^{54}$ model funkcjonowania. Autorzy, dysponując nieco odmiennymi danymi oraz stosując różne metody badawcze, dochodzą do zasadniczo rozbieżnych wniosków.

$\mathrm{Na}$ tle zarysowanej historii badań obszar, jaki stanowi przedmiot tej pracy, nie był szczegółowo rozważany. Większość z omówionych analiz dotyczy skrajnych punktów kujawskiej ekumeny „późnowstęgowej” - strefy czarnych ziem typu kujawskiego (centrum kruszańskiego i centrum brzeskiego), pomijając tereny centrum Wysoczyzny Kujawskiej. Do pewnego stopnia usprawiedliwiał to ówczesny stan rozpoznania tej strefy, jednak suma efektów nowych badań, ilustrowana m.in. wzrostem liczby znanych punktów osadniczych KPCW z 18 rejestrowanych do $1980^{55}$ do 82 stanowisk lokalizowanych obecnie (por. mapa 1), daje szanse na pogłębienie analiz dotyczących osadnictwa „późnowstęgowego" tej przestrzeni.

Odnośnie do definicji taksonu, będącego przedmiotem tej pracy, oraz kontrowersji, jakie budzi stosowanie odmiennych form nazewnictwa funkcjonujące na przestrzeni czasu i w różnych ośrodkach naukowych, za najbardziej spójną, a jednocześnie dążącą do zawarcia pewnego konsensusu w tej kwestii, uznaję propozycję L. Czerniaka ${ }^{56}$ odnośnie do stosowania nazwy kultura brzesko - kujawska (KBK), z taksonomicznym i chronologicznym poszerzeniem tego terminu o materiały związane z ceramiką „,kłutą”.

\section{2. ŹRÓDŁA. STANOWISKA DIAGNOSTYCZNE}

Stanowiska określone tu mianem diagnostycznych zostały zbadane wykopaliskowo na przełomie wiosny i lata $2002 \mathrm{r}$. Prace prowadzone w trybie ratowniczym poprzedzały planowaną inwestycję liniową - budowę ropociągu PKN Orlen - Petrociągu (w skrócie dalej PET), dlatego każdemu z omawianych stanowisk oprócz numeru w danej miejscowości podczas realizacji inwestycji nadano kolejny numer. Poniżej podana jest krótka charakterystyka wybranych trzech $\mathrm{z}$ tych stanowisk, na których zdiagnozowano materiały „późnowstęgowe”; uzupełnieniem tych informacji są tabele załączony do prezentowanej pracy (tab. 1 oraz 2).

\footnotetext{
${ }^{53}$ Czerniak, Piontek 1979

${ }^{54}$ Grygiel 1986; 2008.

${ }^{55}$ Czerniak 1980, kat. II, mapa 3.

${ }^{56}$ Czerniak 1996 b.
} 


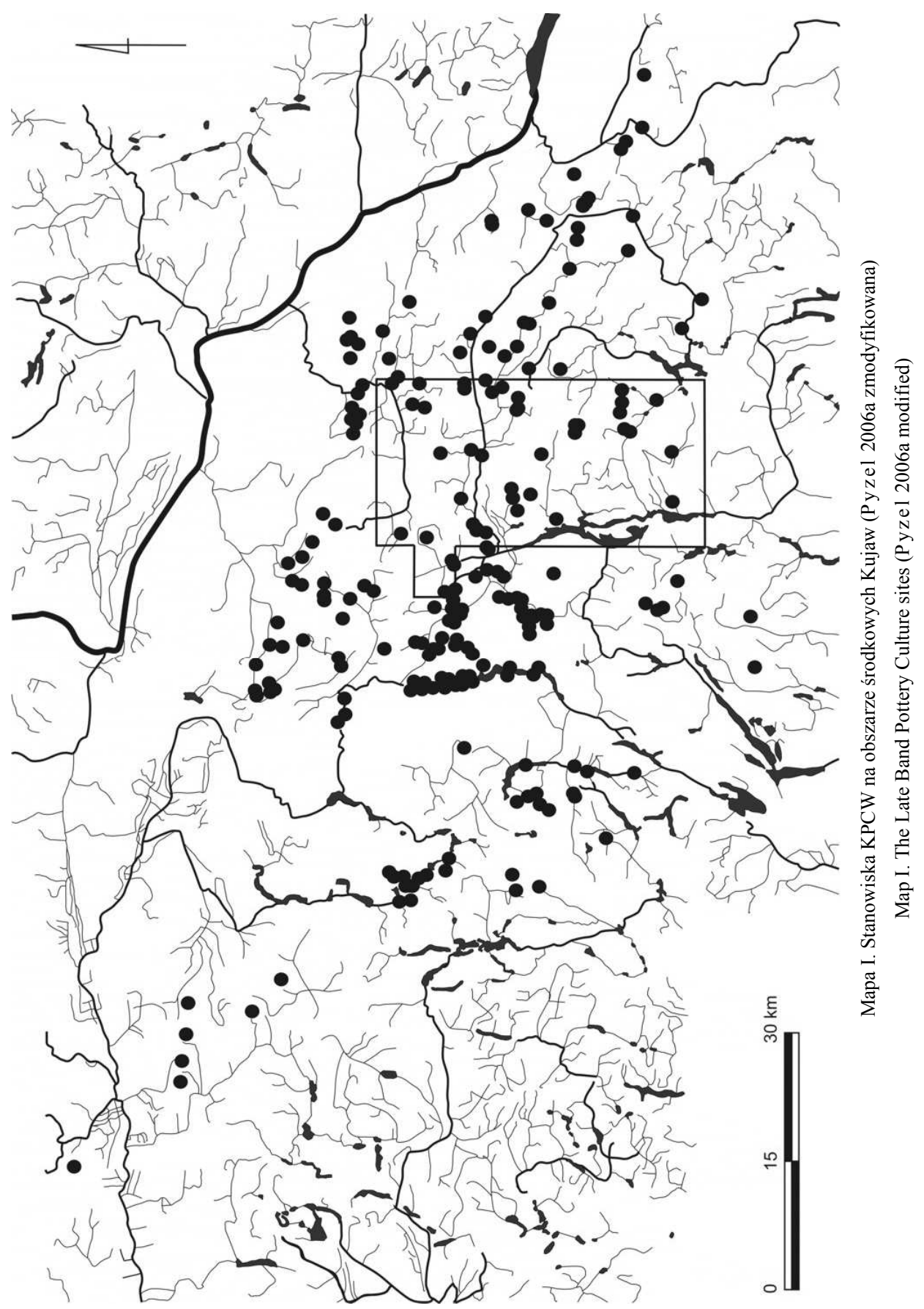




\subsection{Ogólna charakterystyka stanowisk}

$\mathrm{Na}$ omawianych trzech stanowiskach ,późnowstęgowych”: Chełmiczki, stan. 10 (PET 47), Karczyn, stan. 21/22 (PET 30) oraz Olszewice, stan. 7 (PET 18a) zarejestrowano łącznie 717 fragmentów ceramiki, 40 fragmentów polepy i 405 fragmentów kości. Ogólną charakterystykę materiałów ,późnowstęgowych” pozyskanych z tych stanowisk przedstawiono w tabelach 1 i 2 .

Tabela 1. Charakterystyka stanowisk

Table 1. The sites characteristics

\begin{tabular}{|c|c|c|c|c|c|}
\hline \multirow{2}{*}{$\begin{array}{c}\text { Położenie } \\
\text { fizycznogeograficzne }\end{array}$} & \multirow{2}{*}{ Pokrywa glebowa $^{57}$} & \multicolumn{2}{|c|}{ Badania rozpoznawcze } & \multirow{2}{*}{ Etapy zasiedlenia } & \multirow{2}{*}{ Rycina } \\
\hline & & Powierzchniowe & Wykopaliskowe & & \\
\hline \multicolumn{6}{|c|}{ CHELMICZKI, STAN. 10} \\
\hline $\begin{array}{l}\text { Stanowisko znajduje się } \\
\text { w północno-zachodniej } \\
\text { części Pojezierza Kujaw- } \\
\text { skiego. Zlokalizowane jest } \\
\text { w krawędziowej strefie } \\
\text { płaskodennej doliny, będą- } \\
\text { cej dawna odnogą jeziora } \\
\text { Gopło. Lokuje się częścio- } \\
\text { wo na zachodnim stoku } \\
\text { największego w okolicy } \\
\text { pagórka oraz kulminacji } \\
\text { i północno-zachodniej partii } \\
\text { sąsiedniego wzniesienia. } \\
\text { Obie formy krajobrazu } \\
\text { dzieli v-kształtna dolinka } \\
\text { niewielkiego cieku. }\end{array}$ & $\begin{array}{l}\text { Pokrywę glebowa sta- } \\
\text { nowią bielice wy- } \\
\text { kształcone na podłożu } \\
\text { gliniastym. Charakte- } \\
\text { rystyka typów gleb } \\
\text { w promieniu } 1 \mathrm{~km} \text { od } \\
\text { stanowiska wykazuje } \\
\text { największy procento- } \\
\text { wy udział - } 81,82 \% \\
\text { czarnych ziem, na } \\
\text { drugim miejscu znaj- } \\
\text { dują się gleby bagien- } \\
\text { ne- } 13,89 \% \text { oraz } \\
\text { dalej bielicowe - } \\
4,29 \% \text {. }\end{array}$ & $\begin{array}{l}\text { Obszar został rozpoznany } \\
\text { w trakcie badan po- } \\
\text { wierzchniowych prowa- } \\
\text { dzonych przez ZBK, na- } \\
\text { stępnie był weryfikowany } \\
\text { w trakcie badań AZP w } \\
1984 \text { r. oraz rozpoznania } \\
\text { konserwatorskiego bezpo- } \\
\text { średnio poprzedzającego } \\
\text { budowę petrociągu. Wiel- } \\
\text { kość stanowiska oszaco- } \\
\text { wano na ok. } 2 \text { ha. Uzyska- } \\
\text { ne materiały pozwoliły na } \\
\text { zaklasyfikowanie tego } \\
\text { miejsca jako osady kultury } \\
\text { przeworskiej z okresu } \\
\text { wpływów rzymskich, ślad } \\
\text { osadniczy z okresu wcze- } \\
\text { snego i późnego średnio- } \\
\text { wiecza oraz nowożytności. } \\
\end{array}$ & $\begin{array}{l}\text { Ratownicze bada- } \\
\text { nia wykopaliskowe } \\
\text { umożliwiły rozpo- } \\
\text { znanie łącznej } \\
\text { powierzchni } 27,26 \\
\text { arów, ujętych } \\
\text { w pas wytyczony } \\
\text { na linii } \mathrm{N}-\mathrm{S} \text {, } \\
\text { o szerokości } 7 \mathrm{~m} \\
\text { i długości } 389,5 \mathrm{~m}, \\
\text { podzielony na pięć } \\
\text { odcinków (A, B, C, } \\
\text { D, E). }\end{array}$ & $\begin{array}{l}\text { KCWR, } \\
\text { KPCW, } \\
\text { KPL, } \\
\text { Kultura przeworska }\end{array}$ & ryc. 1 \\
\hline \multicolumn{6}{|c|}{ KARCZYN, STAN. 21/22 } \\
\hline $\begin{array}{l}\text { Obszar położony jest na } \\
\text { krawędzi i zboczu pradoliny } \\
\text { rzeki Bachorzy w obrębie } \\
\text { mezoregionu Równiny } \\
\text { Inowrocławskiej w jej } \\
\text { południowo-zachodniej } \\
\text { części. Zajmuje teren cypla } \\
\text { wyodrębnionego rozcięciem } \\
\text { krawędzi przez sucha } \\
\text { dolinkę. }\end{array}$ & $\begin{array}{l}\text { Pokrywę glebową } \\
\text { stanowią czarne zie- } \\
\text { mie wykształcone na } \\
\text { podłożu piaszczystym } \\
\text { i gliniastym. Analiza } \\
\text { typów gleb wykonana } \\
\text { metodą site catchment } \\
\text { w promieniu } 1 \text { km od } \\
\text { stanowiska wykazuje } \\
\text { największy udział na } \\
\text { tym obszarze czar- } \\
\text { nych ziem - } 35,44 \% \\
\text { dalej } 41,42 \% \text { stanowią } \\
\text { gleby bagienne, } \\
13,65 \% \text { gleby bieli- } \\
\text { cowe oraz } 6,22 \% \\
\text { pseudobielicowe. }\end{array}$ & $\begin{array}{l}\text { Stanowisko zostało rozpo- } \\
\text { znane w wyniku prospekcji } \\
\text { powierzchniowej prowa- } \\
\text { dzonej na przełomie lat } 60 . \\
\text { i 70. przez ZBK KA i IP } \\
\text { UAM. Jego dalsza weryfi- } \\
\text { kacja związana była z rea- } \\
\text { lizacją projektu AZP oraz } \\
\text { badaniami powierzchnio- } \\
\text { wymi poprzedzający } \\
\text { budowę Petrociągu. }\end{array}$ & $\begin{array}{l}\text { Badania wykopali- } \\
\text { skowe prowadzone } \\
\text { w trybie ratowni- } \\
\text { czym, realizowane } \\
\text { były w czterech } \\
\text { sezonach (rok } \\
2002,2003,2005 . \\
2006 \text { ) i pozwoliły } \\
\text { na zbadanie łącznej } \\
\text { powierzchni ok. } 94 \\
\text { arów (ryc. 2). }\end{array}$ & $\begin{array}{l}\text { KCWR, KPCW, } \\
\text { KPL } \\
\text { Epoka brązu, } \\
\text { Okres wpływów } \\
\text { rzymskich }\end{array}$ & ryc. 2 \\
\hline
\end{tabular}

${ }^{57}$ Przedstawiona tu charakterystyka typów gleb wykonana została przez Pyzel 2006 a i wraz z założeniami metodycznymi tego zabiegu prezentowana jest w jej pracy. 
cd. tab. 1

\begin{tabular}{|c|c|c|c|c|c|}
\hline \multirow{2}{*}{$\begin{array}{c}\text { Położenie } \\
\text { fizycznogeograficzne }\end{array}$} & \multirow{2}{*}{ Pokrywa glebowa } & \multicolumn{2}{|c|}{ Badania rozpoznawcze } & \multirow{2}{*}{ Etapy zasiedlenia } & \multirow{2}{*}{ Rycina } \\
\hline & & Powierzchniowe & Wykopaliskowe & & \\
\hline \multicolumn{6}{|c|}{ OLSZEWICE, STAN. 7} \\
\hline $\begin{array}{l}\text { Stanowisko znajduje się na } \\
\text { obszarze niewielkiego } \\
\text { cypla, na obrzeżu rozległej } \\
\text { zabagnionej kotliny }\end{array}$ & $\begin{array}{l}\text { Charakterystyka } \\
\text { typów gleb w promie- } \\
\text { niu } 1 \text { km od stanowi- } \\
\text { ska wykazuje znaczną } \\
\text { przewagę czarnych } \\
\text { ziem - } 98,26 \% \text { z nie- } \\
\text { wielkim uzupełnie- } \\
\text { niem - } 1,74 \% \text { - gleb } \\
\text { bielicowych. }\end{array}$ & $\begin{array}{l}\text { Prezentowane stanowisko } \\
\text { zostało odkryte w efekcie } \\
\text { nadzoru archeologicznego } \\
\text { prowadzonego nad pracami } \\
\text { związanymi z budową Pe- } \\
\text { trociągu. Ze względu na nie- } \\
\text { dostępność terenu niemoż- } \\
\text { liwe było wówczas rozpoz- } \\
\text { nanie zasięgu stanowiska } \\
\text { w kierunku północnym i } \\
\text { południowym. Eksploracja } \\
\text { prowadzona była w pasie } \\
\text { W - E w ramach wykopów } \\
5 \times 10 \text { m oraz } 1 \times 10 \text { m. } \\
\text { Łącznie zbadano po- } \\
\text { wierzchnię } 4,7 \text { arów. }\end{array}$ & $\begin{array}{l}\text { Ponownie stanowi- } \\
\text { sko zostało zwery- } \\
\text { fikowane w trakcie } \\
\text { badań AZP w roku } \\
2005 \text { a jego wiel- } \\
\text { kość oszacowano } \\
\text { na } 0,5 \text { ha. }\end{array}$ & $\begin{array}{l}\text { KPCW, } \\
\text { KPL, } \\
\text { Wczesne średnio- } \\
\text { wiecze, } \\
\text { Nowożytność }\end{array}$ & ryc. 3 \\
\hline
\end{tabular}

Tabela 2. Zestawienie materiałów źródłowych KPCW ze stanowisk diagnostycznych

Table 2. List of the Late Band Pottery Culture materials from diagnostic sites

\begin{tabular}{|c|c|c|c|c|c|c|c|c|}
\hline \multirow{2}{*}{$\begin{array}{l}\text { Miejscowość } \\
\text { Stanowisko }\end{array}$} & \multicolumn{2}{|c|}{ Lokalizacja } & \multicolumn{5}{|c|}{ Źródła ruchome } & \multirow{2}{*}{ Uwagi } \\
\hline & Obiekt & Wykop & Ceramika & Krzemienie & Polepa & Kości & Inne & \\
\hline \multirow{20}{*}{ Chełmiczki 10} & - & D2 & 2 & - & - & 5 & & \\
\hline & - & D3 & 16 & - & 38 & 29 & & \\
\hline & - & D5 & 2 & - & - & 6 & & *ob.D54 \\
\hline & - & D5 & 3 & - & - & - & & *ob.D168 \\
\hline & - & D5 & 9 & - & 2 & 7 & & \\
\hline & - & $\mathrm{D} 5 / 6$ & 2 & 3 & 57 & 94 & & *ob.D205 \\
\hline & - & D6 & 22 & 3 & 22 & 321 & & \\
\hline & D139 & D8 & 10 & - & 4 & - & & \\
\hline & D144 & D8 & 5 & 6 & 43 & 49 & & \\
\hline & - & D8 & 44 & 2 & 22 & 13 & & \\
\hline & - & D10 & 2 & - & - & 17 & & *ob.D63 \\
\hline & - & D10 & 1 & - & - & - & & \\
\hline & - & D14 & 1 & - & - & 16 & & *ob.D10 \\
\hline & - & D14 & 1 & - & - & 14 & & *ob.D14 \\
\hline & D15 & D14 & 1 & - & - & - & & \\
\hline & - & D15 & 4 & - & 2 & 107 & & \\
\hline & - & D17 & 8 & - & 48 & 105 & & \\
\hline & - & D18 & 1 & - & 3 & 2 & & \\
\hline & - & D20 & 99 & - & 4 & 30 & & \\
\hline & - & E1a & 1 & - & - & - & & \\
\hline \multicolumn{9}{|c|}{$\Sigma 235$} \\
\hline \multirow{5}{*}{ Karczyn 21/22 } & - & 26 & 20 & 1 & 1 & 11 & & \\
\hline & 97 & 26 & 1 & 1 & - & 31 & & \\
\hline & - & 27 & 1 & 1 & - & 2 & & \\
\hline & - & 28 & 1 & - & - & 2 & & \\
\hline & - & 28 & 3 & - & 2 & 3 & & *ob.95 \\
\hline
\end{tabular}


cd. tab. 2

\begin{tabular}{|c|c|c|c|c|c|c|c|c|}
\hline \multirow{2}{*}{$\begin{array}{c}\text { Miejscowość } \\
\text { Stanowisko }\end{array}$} & \multicolumn{2}{|c|}{ Lokalizacja } & \multicolumn{5}{|c|}{ Źródła ruchome } & \multirow{2}{*}{ Uwagi } \\
\hline & Obiekt & Wykop & Ceramika & Krzemienie & Polepa & Kości & Inne & \\
\hline \multirow{43}{*}{ Karczyn 21/22 } & - & 28 & 3 & - & - & 19 & & *ob.96 \\
\hline & - & $68 \mathrm{a}$ & 2 & - & - & 3 & & *ob.217 \\
\hline & 232 & $69 / 70 \mathrm{~b}$ & 2 & 1 & - & 8 & & \\
\hline & - & $69 / 68 / 67 \mathrm{~b}$ & 2 & - & - & 10 & & *ob.233 \\
\hline & - & $69 / 68 / 67 \mathrm{~b}$ & - & - & - & 17 & & *ob240 \\
\hline & 216 & $70 a$ & 9 & - & - & - & & \\
\hline & - & $312 b$ & 1 & 1 & - & 1 & & \\
\hline & - & $313 b$ & 1 & - & - & 1 & & \\
\hline & - & $315 b$ & 2 & - & - & 1 & & \\
\hline & - & $317 \mathrm{~b}$ & 1 & - & - & - & & \\
\hline & - & $318 \mathrm{~b}$ & 1 & - & - & - & & \\
\hline & - & $322 \mathrm{a}$ & 10 & 1 & - & 4 & & \\
\hline & - & $322 b$ & 7 & 3 & - & 8 & & \\
\hline & - & $322 \mathrm{~b}$ & 5 & 16 & - & 86 & & *ob.295 \\
\hline & - & $323 \mathrm{a}$ & 2 & 1 & - & 1 & & \\
\hline & - & $325 b$ & 2 & 3 & - & - & & \\
\hline & 317 & $326 a$ & 5 & - & - & - & & \\
\hline & - & $326 \mathrm{~b}$ & 1 & - & - & - & & \\
\hline & - & $327 \mathrm{a}$ & 1 & - & - & 13 & & \\
\hline & - & III b & 6 & - & - & - & & \\
\hline & - & $\mathrm{IV} \mathrm{b}$ & 15 & - & 1 & 21 & & \\
\hline & - & $\mathrm{Vb}$ & 1 & - & - & 7 & & \\
\hline & - & VIII a & 1 & & - & 1 & & *ob.324 \\
\hline & - & VIII a & 1 & - & - & 118 & & *ob.322 \\
\hline & - & VIII a & 7 & 1 & - & 17 & & \\
\hline & - & $\mathrm{IX} \mathrm{b}$ & 4 & - & - & - & & \\
\hline & - & $\mathrm{Xb}$ & 1 & - & - & - & & \\
\hline & - & $\mathrm{XI}$ a & 2 & - & - & 11 & & *ob.337 \\
\hline & - & XI a & 1 & - & - & - & & *ob.339 \\
\hline & - & XI a & - & - & - & - & & *ob.346 \\
\hline & - & XII a & 2 & - & 1 & - & & \\
\hline & - & XII a & 4 & - & - & - & & *ob.333 \\
\hline & $333 a$ & XII a & 2 & - & - & 9 & & \\
\hline & - & XIII & 2 & 3 & 2 & 412 & & *ob.325 \\
\hline & - & XIIIa & 1 & - & - & - & & *ob. 296 \\
\hline & - & XIIIIa & 4 & - & - & 7 & & \\
\hline & - & XIV a & 1 & 1 & - & 8 & & \\
\hline & - & XIV a & 4 & - & 7 & 27 & & *ob.350 \\
\hline & - & $\mathrm{XV}$ a & 14 & - & - & - & & \\
\hline & 367 & XVII b & 1 & - & - & - & & \\
\hline & - & XVII b & 8 & - & 3 & - & & \\
\hline & - & XVIII a & 3 & 1 & - & 14 & & \\
\hline & - & XVIII a & 1 & - & - & - & & *ob.429 \\
\hline
\end{tabular}


cd. tab. 2

\begin{tabular}{|c|c|c|c|c|c|c|c|c|}
\hline \multirow{2}{*}{$\begin{array}{l}\text { Miejscowość } \\
\text { Stanowisko }\end{array}$} & \multicolumn{2}{|c|}{ Lokalizacja } & \multicolumn{5}{|c|}{ Źródła ruchome } & \multirow{2}{*}{ Uwagi } \\
\hline & Obiekt & Wykop & Ceramika & Krzemienie & Polepa & Kości & Inne & \\
\hline \multirow{9}{*}{ Karczyn 21/22 } & 403 & XVIII a & 1 & - & - & - & & \\
\hline & 371 & XVIII b & 4 & - & - & 5 & & \\
\hline & - & XVIII b & 8 & - & - & 51 & & *ob. 372 \\
\hline & - & XIX b & 2 & - & - & 3 & & \\
\hline & - & $\mathrm{XX} \mathrm{b}$ & 1 & - & - & - & & *ob. 360 \\
\hline & - & XXV b & 1 & - & - & - & & \\
\hline & - & XXV b & 1 & - & 3 & - & & *ob. 383 \\
\hline & - & XXV b & 1 & & 5 & - & 1 kamień & *ob. 384 \\
\hline & 386 & XXV b & 2 & - & 3 & 3 & & \\
\hline \multicolumn{9}{|c|}{$\Sigma 192$} \\
\hline \multirow{7}{*}{ Olszewice 7} & - & 3 & 2 & - & 1 & - & & *ob. 2 \\
\hline & 3 & 4 & 6 & - & - & 24 & & \\
\hline & $4 a$ & 4 & 4 & - & - & - & & \\
\hline & 5 & 5 & 6 & - & - & 4 & & \\
\hline & $4 \mathrm{~b}$ & 5 & 9 & - & - & - & & \\
\hline & 9 & 9 & 91 & - & 1 & 62 & rozciracz & \\
\hline & 10 & 9 & 30 & - & 2 & 15 & toporek & \\
\hline \multicolumn{9}{|c|}{$\Sigma 148$} \\
\hline
\end{tabular}

* Obiekty, w których materiały KPCW wystąpiły na złożu wtórnym.

\section{2. Źródła ruchome}

Analiza specyfikująca, przeprowadzona w tej części pracy, dotyczyła klasyfikacji cech ceramiki oraz informacji z dziedziny archeozoologii.

\subsubsection{Ceramika}

Analiza cech ceramiki dokonana została na podstawie następujących kategorii: technologie, makromorfologie, mikromorfologie oraz zdobnictwo.

\subsubsection{Technologia ceramiki}

Założenia metodyczne wykorzystane $\mathrm{w}$ tej części pracy sformułowane zostały przez L. Czerniaka i A. Kośkę w 1980 r. Zaproponowany wówczas algorytm datowania technologicznego ceramiki KPCW, oparty na makroskopowych obserwacjach grup czynności techniczno-użytkowych, jest ujęciem nadal obowiązującym i stosowanym w prezentowanym ujęciu.

Przyjęta procedura badawcza realizowana była przez: rekonstrukcję systemu technologicznego oraz opis cech technologicznych badanego zbioru. 


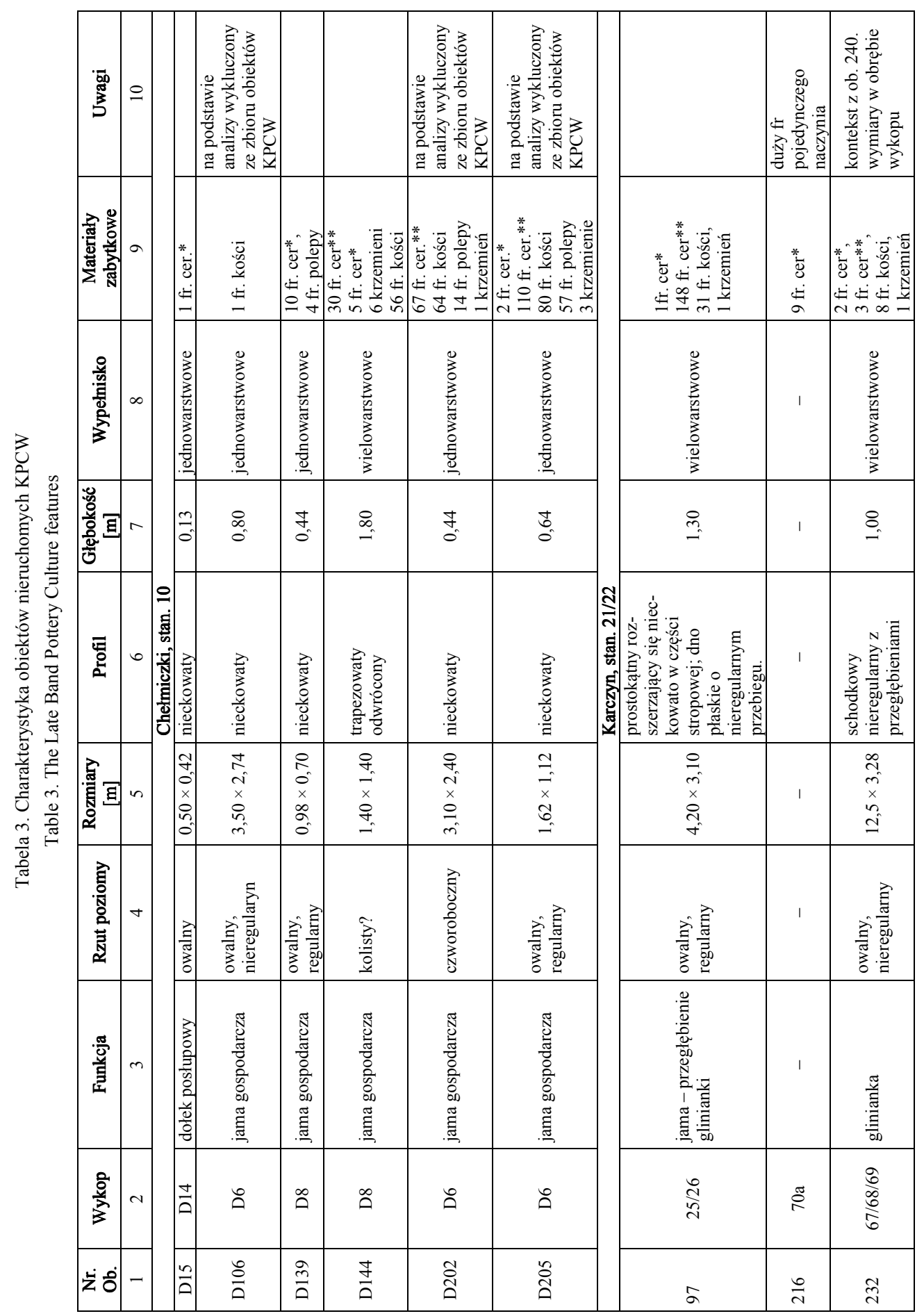




\begin{tabular}{|c|c|c|c|c|c|c|c|c|c|c|c|c|}
\hline & 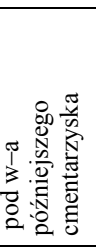 & 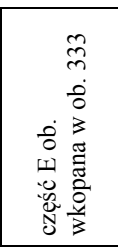 & & & & & 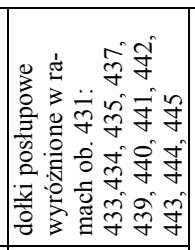 & & & 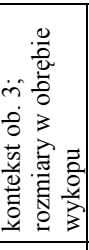 & 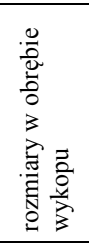 & 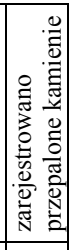 \\
\hline 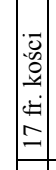 & 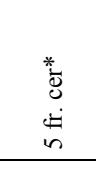 & 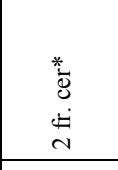 & 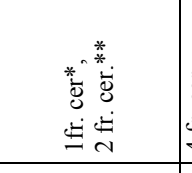 & 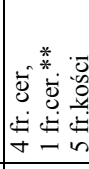 & 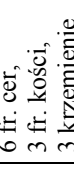 & 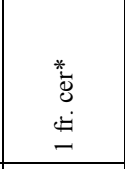 & 1 & & 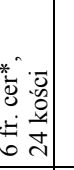 & 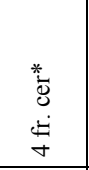 & 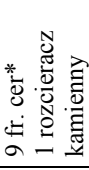 & 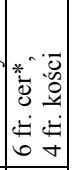 \\
\hline 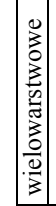 & 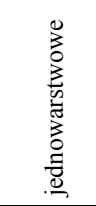 & 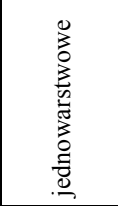 & 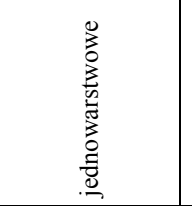 & 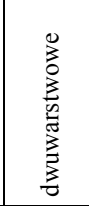 & 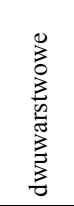 & 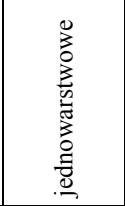 & 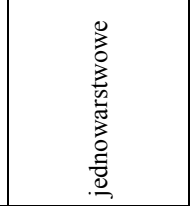 & & 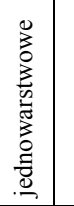 & 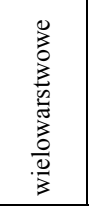 & 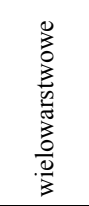 & 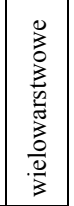 \\
\hline 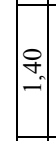 & 1 & $\underset{0}{*}$ & $\begin{array}{l}q \\
9 \\
0 \\
9 \\
0 \\
0\end{array}$ & $\begin{array}{l}n \\
0 \\
0\end{array}$ & nू. & तु & $\begin{array}{l}0 \\
0 \\
0 \\
0 \\
0 \\
0 \\
0\end{array}$ & & ì & $\begin{array}{l}8 \\
0 \\
0 \\
\infty \\
0 \\
0\end{array}$ & $\begin{array}{l}8 \\
0 \\
0 \\
0 \\
0 \\
0\end{array}$ & : \\
\hline 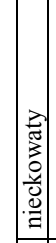 & 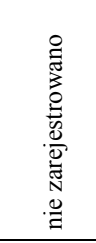 & 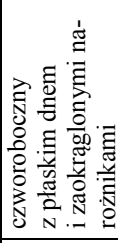 & 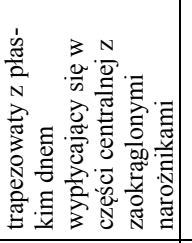 & 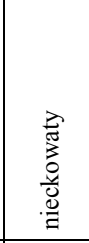 & 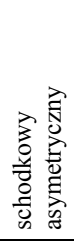 & 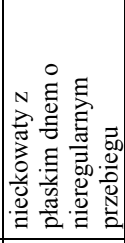 & 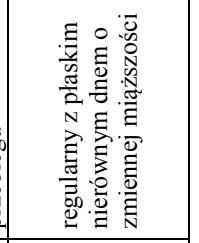 & 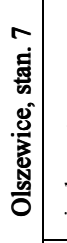 & 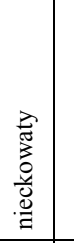 & 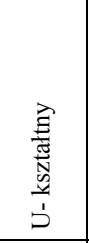 & 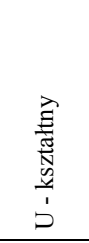 & 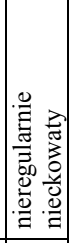 \\
\hline 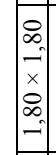 & $\begin{array}{l}\text { ñ } \\
0 \\
x \\
\times \\
0 \\
0 \\
0 \\
0\end{array}$ & 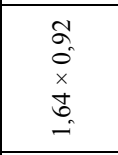 & 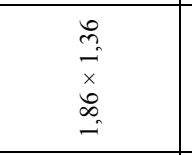 & 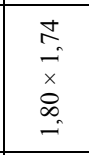 & $\begin{array}{l}\text { R } \\
0 \\
x \\
0 \\
0 \\
i \\
i \\
\end{array}$ & $\begin{array}{l}\infty \\
\infty \\
0 \\
0 \\
x \\
0 \\
0 \\
- \\
\end{array}$ & 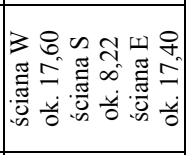 & & 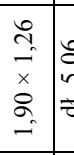 & 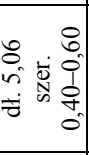 & 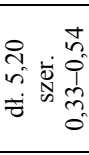 & 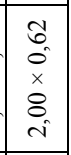 \\
\hline 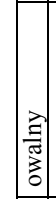 & 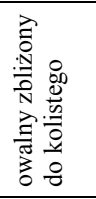 & 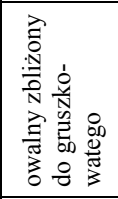 & 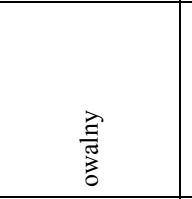 & $\begin{array}{l}\frac{3}{0} \\
\frac{0}{0} \\
\end{array}$ & $\begin{array}{l}\text { 窟 } \\
\text { 岁 }\end{array}$ & 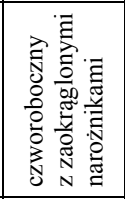 & 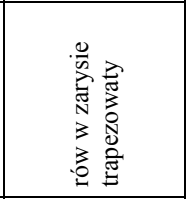 & & 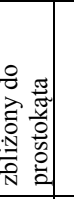 & 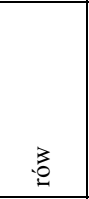 & 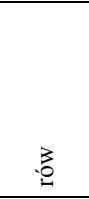 & 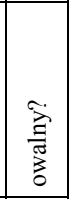 \\
\hline $\mid$ & 总 & 䔍 & 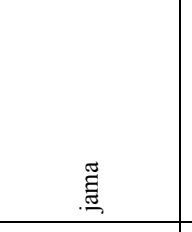 & 䔍 & 䔍 & . & 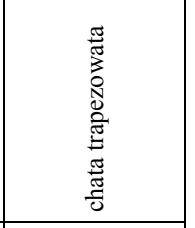 & & 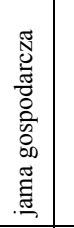 & 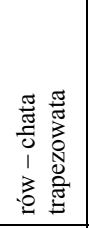 & 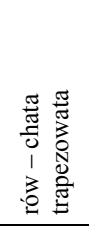 & 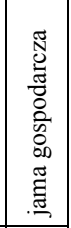 \\
\hline $\overrightarrow{0}$ & $\underset{\widetilde{N}}{\sim}$ & $\bar{x}$ & $\underset{x}{\vec{x}}$ & $\underbrace{f}_{\text {竞 }}$ & $\underset{x}{x}$ & 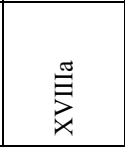 & 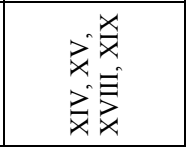 & & $\nabla$ & $\sigma$ & in & in \\
\hline $\begin{array}{l}9 \\
\\
\end{array}$ & 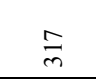 & ల్ల్ & ర్ల & i & $\begin{array}{l}\infty \\
\infty \\
m\end{array}$ & 角 & $\vec{q}$ & & $m$ & 艼 & $f$ & in \\
\hline
\end{tabular}




\begin{tabular}{|c|c|c|c|c|c|c|c|c|c|c|c|c|c|}
\hline 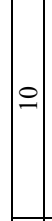 & 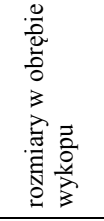 & & 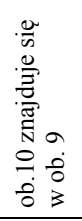 & 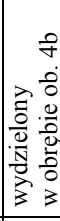 & 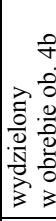 & 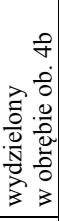 & 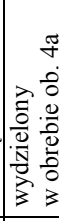 & 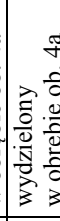 & 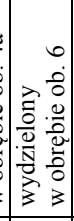 & 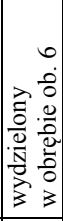 & 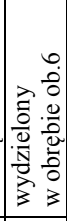 & 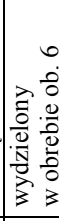 & 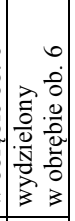 \\
\hline a & 1 & 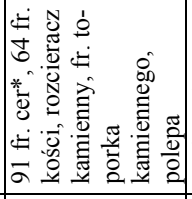 & 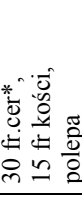 & 1 & 1 & 1 & 1 & 1 & 1 & 1 & 1 & 1 & 1 \\
\hline$\infty$ & 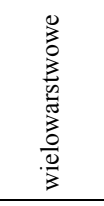 & 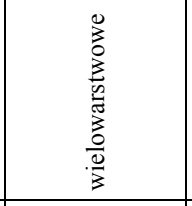 & 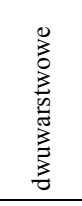 & 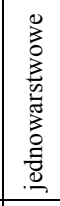 & 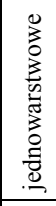 & 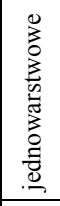 & 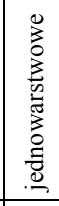 & 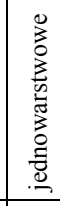 & 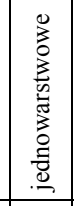 & 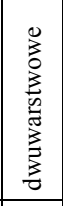 & 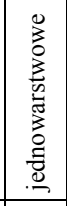 & 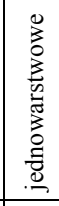 & 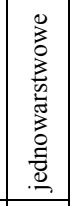 \\
\hline 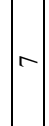 & $\begin{array}{l}8 \\
\circ \\
0 \\
\text { तิ } \\
\text { o. }\end{array}$ & $\stackrel{\Xi}{\Xi}$ & : & 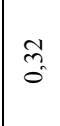 & तે & $\begin{array}{l}\infty \\
0 \\
0 \\
0\end{array}$ & no & g. & ลิ & $\begin{array}{l}0 \\
0 \\
0 \\
0\end{array}$ & 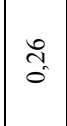 & $\stackrel{8}{:}$ & $\begin{array}{c}0 \\
m_{0}^{0}\end{array}$ \\
\hline 6 & 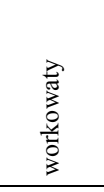 & 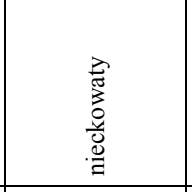 & 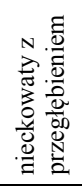 & 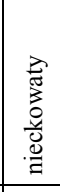 & 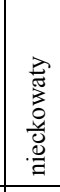 & 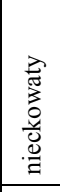 & 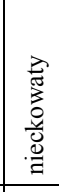 & 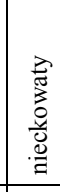 & 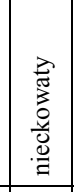 & 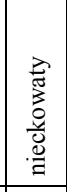 & 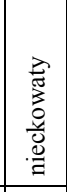 & 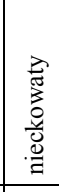 & 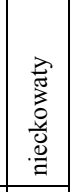 \\
\hline & 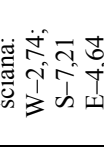 & $\begin{array}{l}\text { ì } \\
\text { i } \\
x \\
8 \\
i \\
i\end{array}$ & 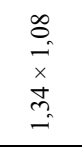 & \begin{tabular}{|l|}
\multirow{2}{*}{} \\
0 \\
0 \\
$x$ \\
0 \\
0 \\
0 \\
\end{tabular} & $\begin{array}{l}\infty \\
0 \\
x \\
\text { î } \\
0 \\
\end{array}$ & \begin{tabular}{|l|}
$t$ \\
0 \\
0 \\
$x$ \\
0 \\
0 \\
0 \\
\end{tabular} & 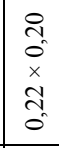 & \begin{tabular}{|l|} 
\\
0 \\
0 \\
$x$ \\
$\infty$ \\
0 \\
0
\end{tabular} & $\begin{array}{l}0 \\
\\
0 \\
x \\
\infty \\
\infty \\
0 \\
0 \\
0\end{array}$ & $\begin{array}{l}0 \\
0 \\
x \\
\infty \\
0 \\
0 \\
\end{array}$ & \begin{tabular}{|l|}
$\frac{\infty}{0}$ \\
0 \\
$\dot{x}$ \\
0 \\
0 \\
0 \\
\end{tabular} & 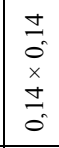 & 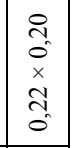 \\
\hline$\nabla$ & 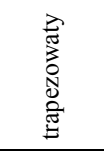 & 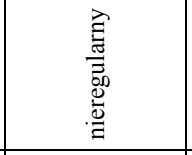 & 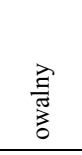 & 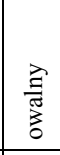 & 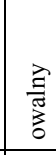 & 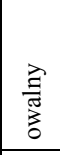 & 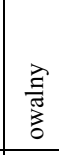 & 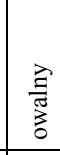 & 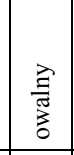 & 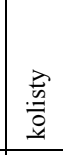 & 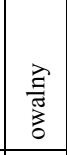 & 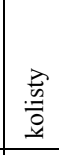 & 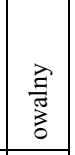 \\
\hline$m$ & 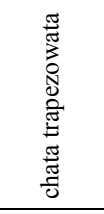 & 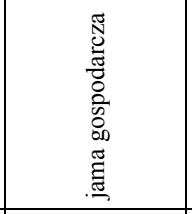 & 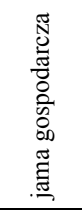 & 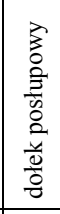 & 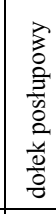 & 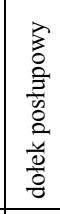 & 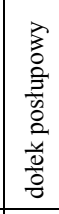 & 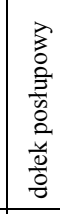 & 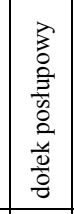 & 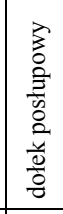 & 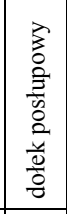 & 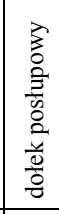 & 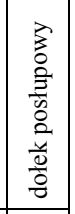 \\
\hline$\sim$ & $r$ & $\sigma$ & $a$ & in & in & in & 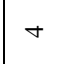 & ナ & r & $r$ & $r$ & $r$ & $r$ \\
\hline & 0 & $a$ & 은 & $\simeq$ & $\underline{2}$ & \pm & $\cong$ & 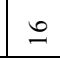 & $=$ & $\stackrel{\infty}{-}$ & 2 & กิ & $\vec{\sim}$ \\
\hline
\end{tabular}




\subsection{Rekonstrukcja systemu technologicznego}

Lista istotnych taksonomicznie czynćności użytkowych

aa - rodzaj domieszki: 1 - piasek; 2 - tłuczeń barwa biało-jasno-szara; 3 - tłuczeń barwa różowa; 4 - mika. ab - granulometria domieszki: 1 - drobnoziarnista - nieintencjonalna? <0,3 mm; 2 - przewaga drobnoziarnistej ze średnioziarnista $(0,8 \mathrm{~mm})$; 3 - równy udział drobno i średnioziarnistej; 4 - przewaga średnioziarnistej z grubą (>1,0 mm ); 5 - przewaga gruboziarnistej ze średnioziarnistą. ac - ilość domieszki: 1 - bardzo mała - wrażenie domieszki nieintencjonalnej; 2 - mała; 3 - średnia; 4 - bardzo duża. ad - charakterystyka uwarstwień przełamu: 1 - jednolity zwarty; 2 - jednolity $\mathrm{z}$ tendencja do granulacji; 3 - niejednolity warowany lub granulowany; 4 - niejednolity z tendencja do pęknięć wzdłużnych. ba - grubość ścianek naczynia: 1 - klasa I $\leq 6,9 \mathrm{~mm}$; 2 - klasa II 7,0 - 9,9 mm; 3 - klasa III $\geq 1,0 \mathrm{~mm}$. bb - wykończenie powierzchni zewnętrznej ścianki naczynia: 1 - gładka równa; 2 - gładka lekko pofalowana; 3 - lekko szorstka pofalowana z wystającą domieszką tłucznia.

Współwystępowanie określonego zestawu cech, rejestrowanych w poszczególnych stanach, pozwala na zdefiniowanie hierarchicznych jednostek systemu technologicznego: grup technologicznych (gt), podgrup technologicznych (pgt) oraz elementów grup technologicznych (egt), stanowiących niepodzielną jednostkę systemu technologicznego (porównaj Czerniak 1980, ryc. 2).

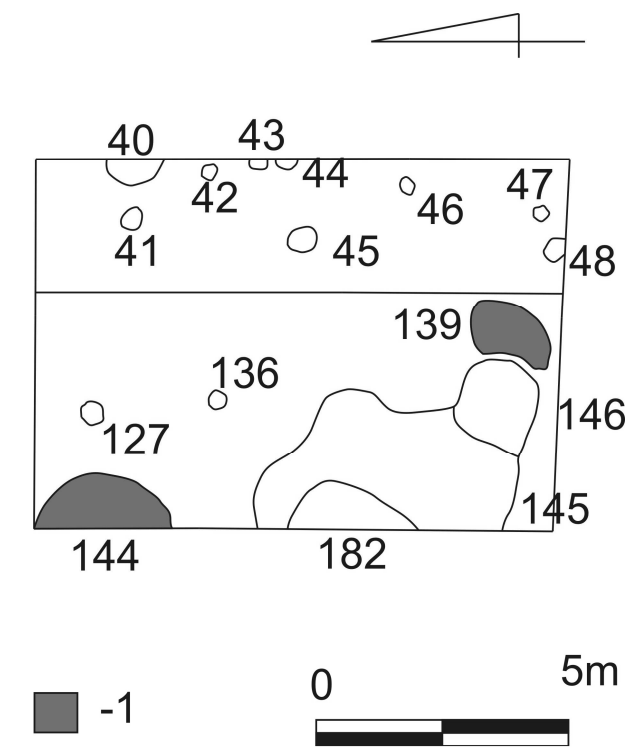

Ryc. 1. Chełmiczki, stan. 10 (PET 47). Rozmieszczenie obiektów w wykopach na odcinku D. 1 - obiekty KPCW Fig. 1. Chełmiczki, site 10 (PET 47). Features distribution in the trenches, section D. 1 - the Late Band Pottery Culture features 


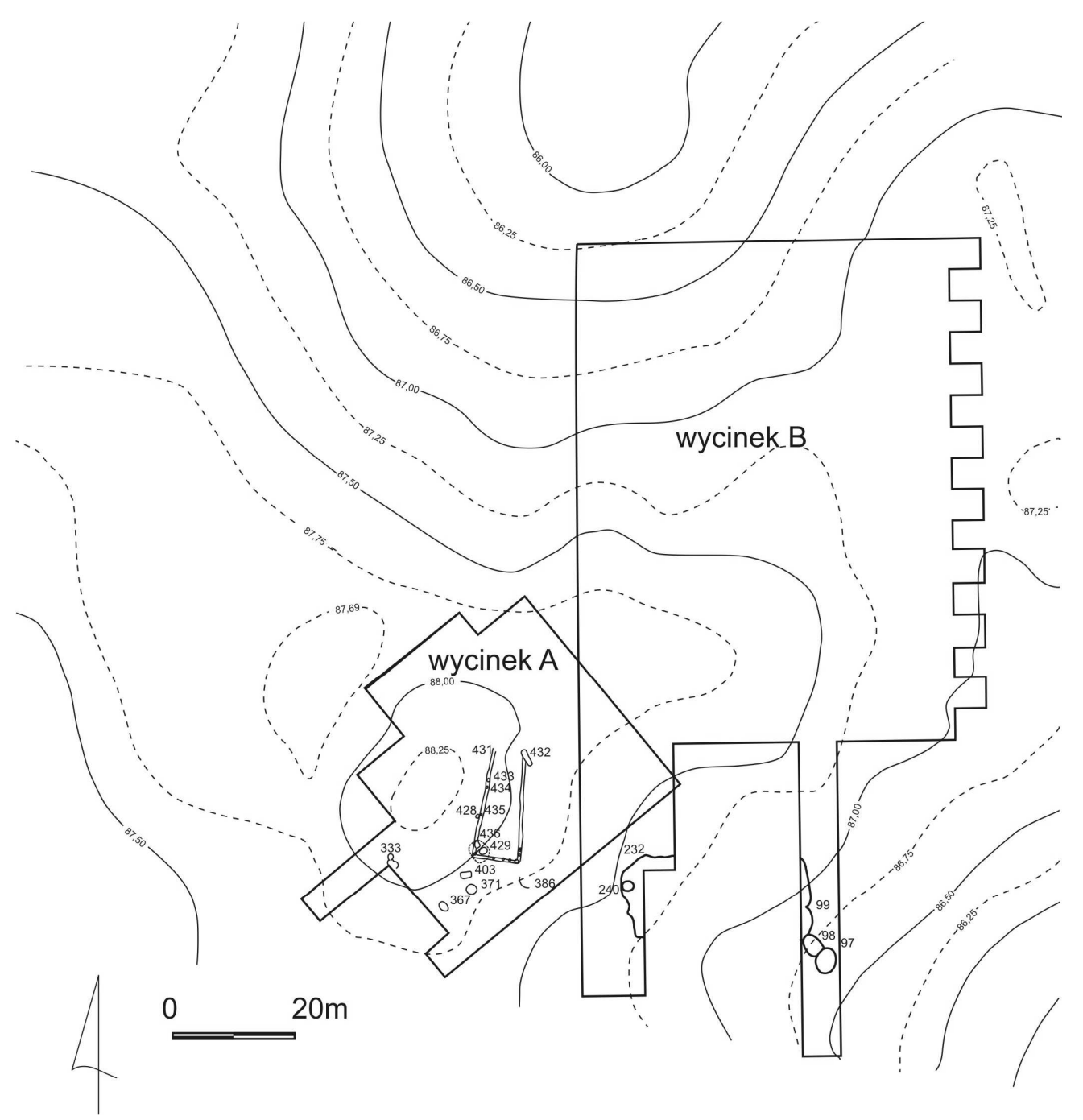

Ryc. 2. Karczyn, stan. 21/22 (PET 30). Plan sytuacyjno wysokościowy. Wycinek A i wycinek B - obszar zbadany wykopaliskowo z zaznaczonymi obiektami ,późnowstęgowymi”

Fig. 2. Karczyn, site 21/22 (PET 30). The site layout. Sector A and B - the excavated area with the marked Late Band Pottery Culture features

Nadrzędne znaczenie przy definiowaniu poszczególnych jednostek systemu technologicznego mają typy techniczne opisujące rodzaj i granulację domieszki ${ }^{58}$.

Konfrontacja wyżej wymienionych norm, w ocenach badanego zbioru ceramiki uzasadnia ich redukcję w punkcie dotyczącym gt IV.

${ }^{58}$ Czerniak, Kośko 1980, s. 268. 

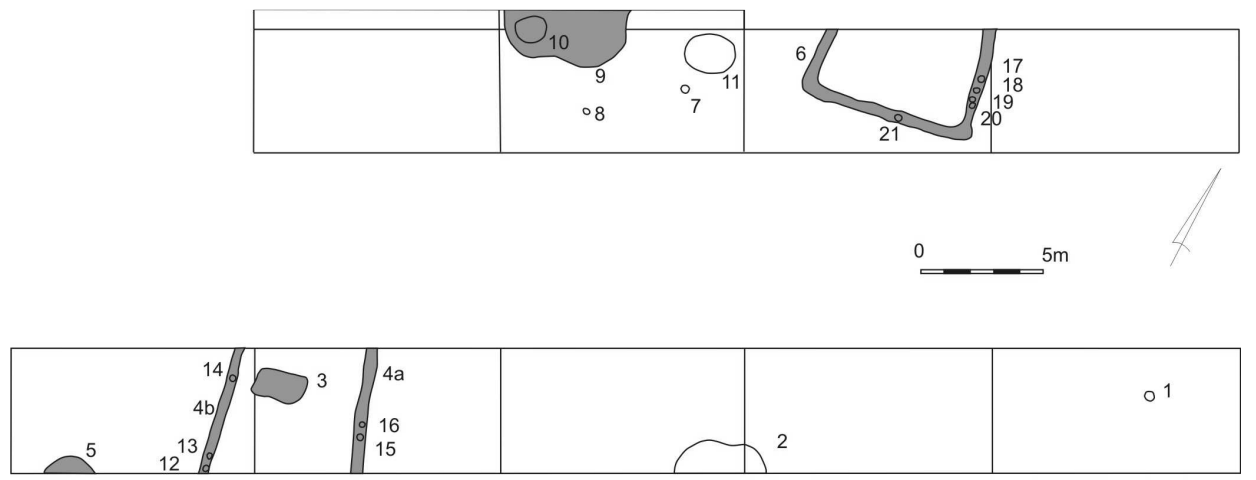

- obiekty KPCW

Ryc. 3. Olszewice, stan. 7 (PET 18a). Rozmieszczenie obiektów w wykopach. 1 - obiekty KPCW Fig. 3. Olszewice, site 7 (PET 18a). Features distribution in the trenches. 1 - the Late Band Pottery Culture features

- Powstała podgrupa IV A/B1 - łącząca grupy IVA i IVB1. Jako cechę dystynktywną, służącą wyróżnienie tego elementu, przyjęto wyraźne występowanie domieszki piasku i miki, w postaci granulatu średnio i drobnoziarnistego w równym udziale. Domieszka ta jest rejestrowana $w$ średniej ilości.

- Za cezurę służącą wydzieleniu kolejnej pgt - IVB2/C, spajającej grupy IVB2 oraz IVC, przyjęto moment, w którym domieszką dominującą staje się biały tłuczeń, o granulacji średniej z obecną domieszką gruboziarnistą.

Uzasadnienie zaproponowanej modyfikacji może być dwojakie. Wiąże się z odmienność badanego zbioru jako efektu pochodnego procesów: (1) podepozycyjnych, objawiających się wysokimi wskaźnikami rozdrobnienia ceramiki, obrazującymi znaczny stopień zniszczenia badanego zbioru oraz (2) może być efektem powstałej mikroregionalnej specyfiki wytwórczości ceramiki, przejawiającej się w sferze technologii, zatarciem różnic decydujących pierwotnie o wydzieleniu skonsolidowanych tu grup technologicznych.

Wymienione cechy uznaje się za kierunkowe przy wyznaczaniu podgrup IVA/B1 i IVB2/C, pozostałe parametry, które opisują te podgrupy, zostały zsumowane i stanowią poszerzenie opisu powstałych jednostek. Pełną specyfikację omawianych elementów oraz pozostałych grup technologicznych stosowany w tym ujęciu przedstawiono w tabeli 4 .

Dalsza analiza informacji uzyskanych na etapie klasyfikacji do egt, polega na wpisaniu uzyskanych danych $\mathrm{w}$ schematyczne ujęcie tabelaryczne stosowane przy opisie struktury technologiczno-stylistycznej ceramiki $\mathrm{KPCW}^{59}$.

\footnotetext{
${ }^{59}$ Np. Czerniak 1992, ryc. 4.
} 
Tabela 4. Opis jednostek budowy systemu technologicznego ceramik KPCW (wg Czerniak 1980, ujęcie zmodyfikowane)

Table 4. Description of building units of the technological system of the Late Band Pottery Culture pottery (by Czerniak 1980, modified)

\begin{tabular}{|l|c|c|c|c|c|}
\hline \multirow{2}{*}{$\begin{array}{c}\text { Grupa } \\
\text { technologiczna* }\end{array}$} & \multicolumn{5}{c|}{ Typ technologiczny** } \\
\cline { 2 - 6 } & aa & ab & ac & ad & bb \\
\hline III A & 1 & $1 / / 2$ & $1 / / 2$ & 1 & 1 \\
\hline III B & $1 / / 2$ & $2 / / 3$ & $3 / / 2$ & 1 & 1 \\
\hline IV A / B1 & $1 / 4 / / 2$ & $3 / 2 / / 4$ & $3 / 4$ & $23 / / 4$ & 1 \\
\hline IV B 2 / C & $24 / 1$ & $4 / 5 / / 3$ & $4 / 3$ & 24 & 2 \\
\hline V A & $2 / 1 / / 4$ & $5 / 4 / / 3$ & $3 / / 4$ & $1 / / 2$ & 2 \\
\hline V B & $3 / / 1 / / 2 / / 4$ & $5 / 4$ & $4 / 3$ & $3 / / 1 / / 2$ & 3 \\
\hline
\end{tabular}

* Oznaczenia czynności użytkowych i ich stanów według listy czynności użytkowych.

** Cecha dominująca / cecha występująca wyraźnie // cecha występująca śladowo.

W efekcie stosowania tego arkusza uzyskano informacje o frekwencji poszczególnych gt i egt korelujące z pomiarami grubości ścianek naczyń, wskaźnikami ilościowo-wagowymi oraz frekwencją ceramiki zdobionej. Uzyskane w ten sposób informacje stanowią podstawę do datowania cech technologicznych badanych zbiorów.

\subsection{Opis cech technologicznych badanego zbioru}

- Na stanowisku Chełmiczki 10 analizie technologii poddano zbiór liczący 229 fragmentów ceramiki, pochodzących z warstwy rejestrowanej w obrębie wykopów, z obiektów, w których materiał KPCW zlokalizowany był na złożu wtórnym oraz $\mathrm{z}$ uwagi na bardzo małą liczebność, również z obiektów KPCW. Uzyskane wyniki prezentuje tabela 5.

- Materiał ceramiczny z Karczyna stan. 21/22 został poddany analizie z uwzględnieniem podziału obszaru stanowiska na części A i B (ryc. 2).

W części A próba technologiczna objęła 103 fragmenty ceramiki. Do analizy włączono ceramikę zdobioną ornamentem kłutym. W części B stanowiska Karczyn 21/22 diagnostyce technologii poddano 84 fragmenty ceramiki KPCW. Nie zarejestrowano ceramiki zdobionej ornamentem kłutym. Rezultaty przeprowadzonego postępowania prezentują tabele 6 i 7 .

- W przypadku stanowiska Olszewice 7 całość analizowanego materiału, liczącego 140 fragmentów, pochodzi z obiektów ,,późnowstęgowych”. Nie odnotowano występowania ceramiki, w obrębie warstwy z wykopów. Wyniki zdecydowałam się zaprezentować w dwóch wersjach: (1) dotyczącej materiałów z wszystkich obiektów KPCW (tab. 8) oraz oddzielnie z obiektów 9 i 10, które są ze sobą ściśle powiązane stratygraficznie i chronologicznie (zbieżne daty ${ }^{14} \mathrm{C}$ ) oraz stanowią zbiór o istotnej liczebności ${ }^{60}$ (tab. 9).

${ }^{60}$ Za zbiór taki uważa się zespół liczący powyżej 50 fragmentów (Czerniak 1980, s. 20). 


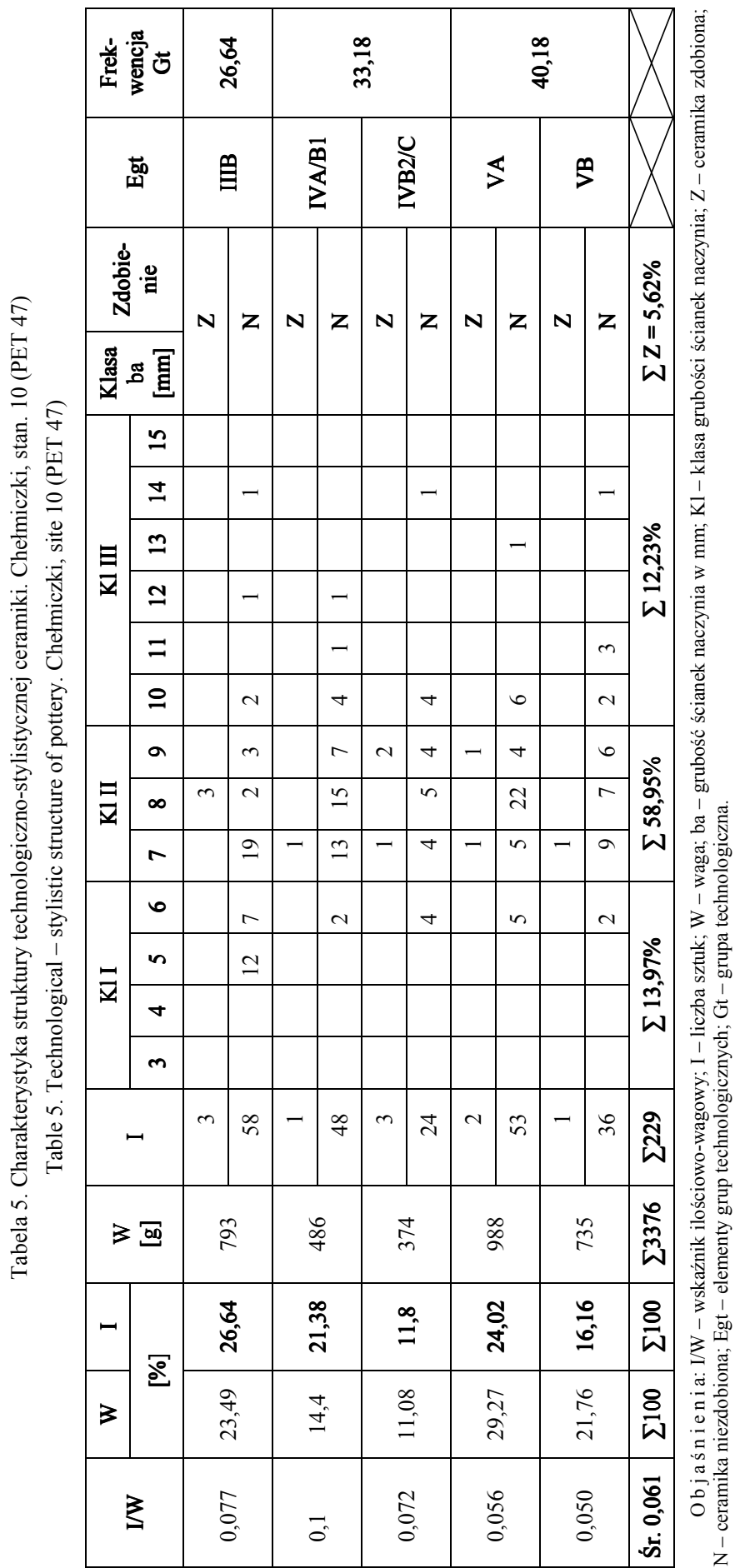




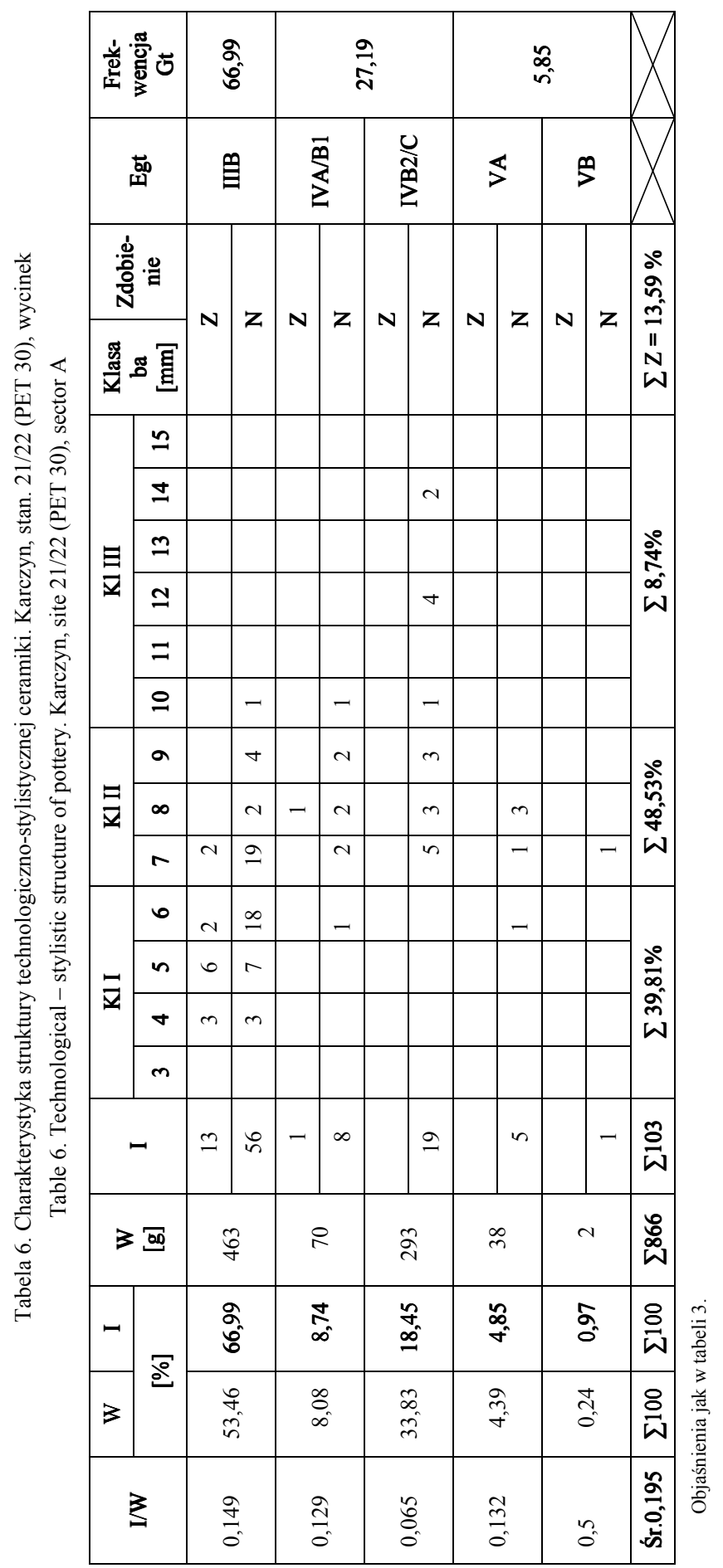




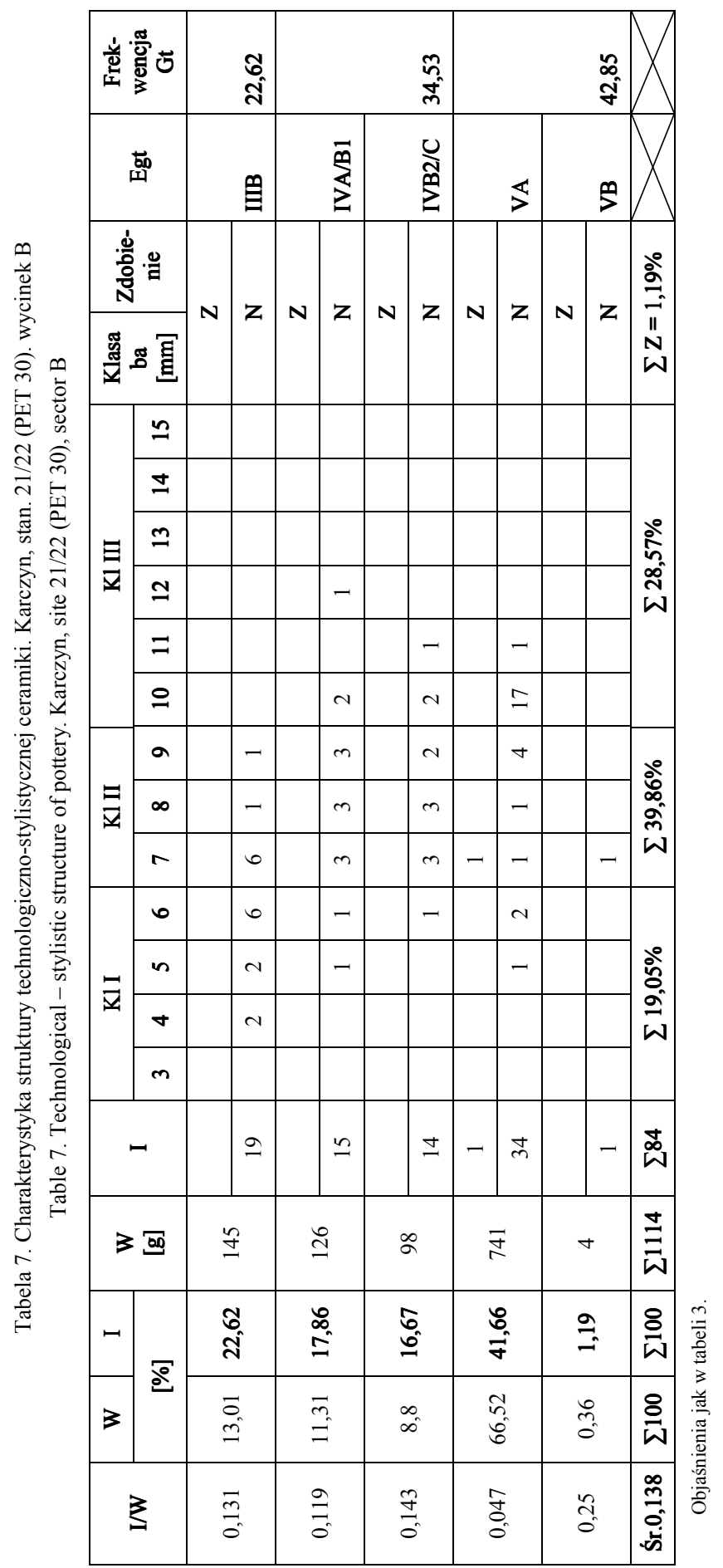




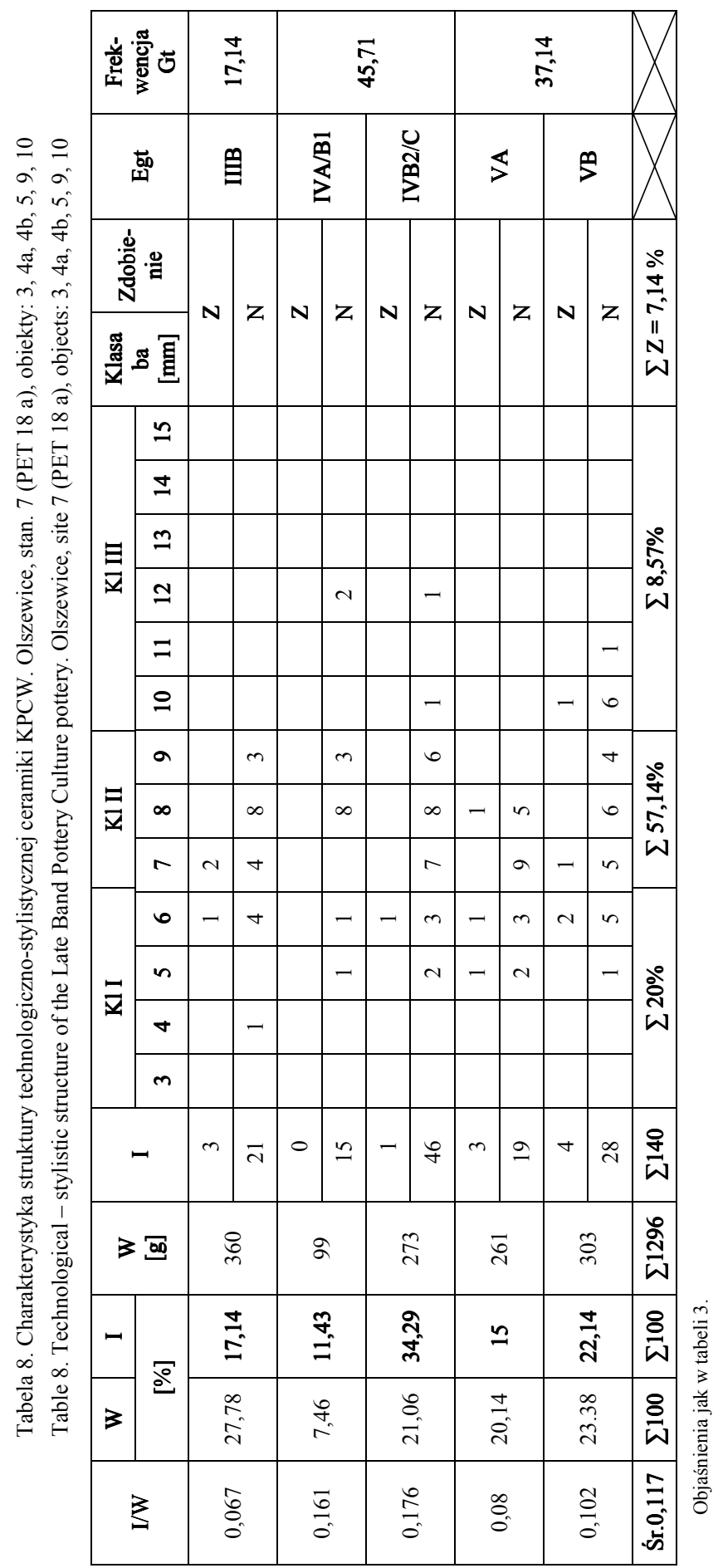




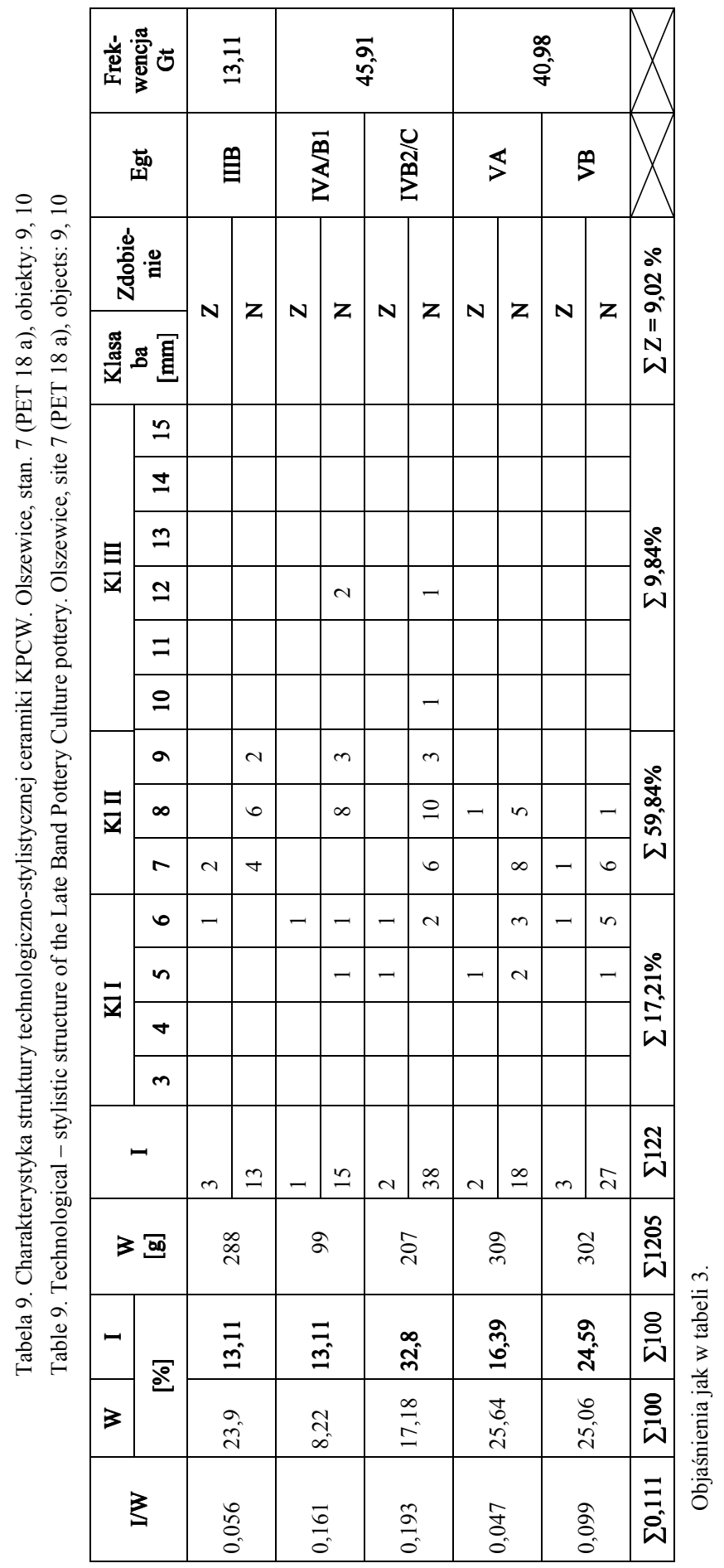



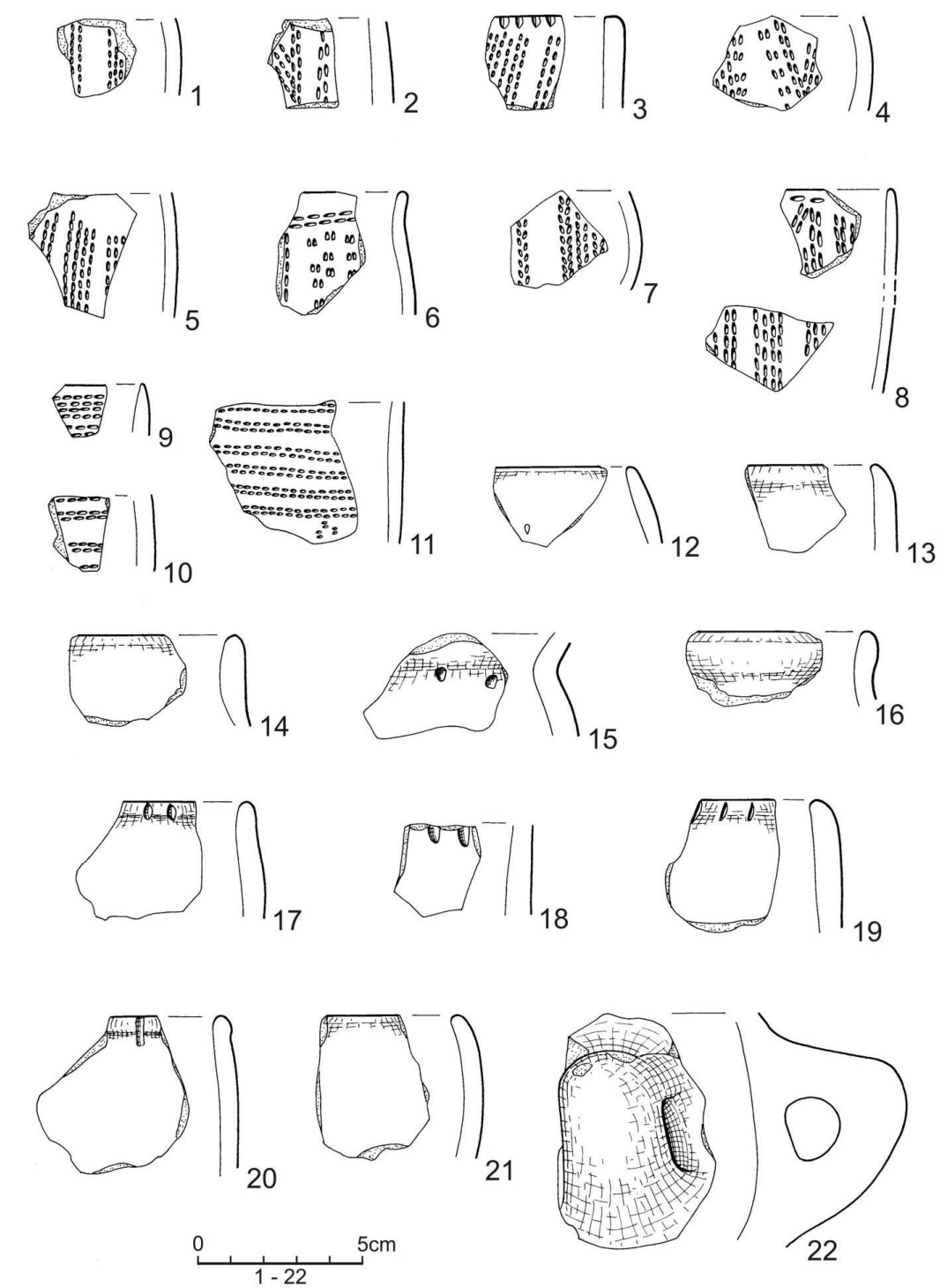

21

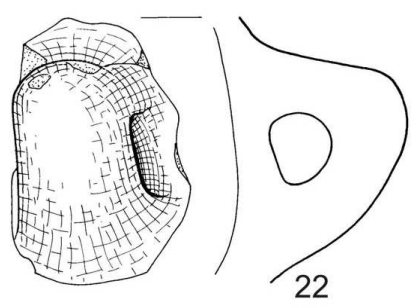

Ryc. 4. Karczyn, stan. 21/22. Elementy wydzielone ceramiki KPCW: wykop III, humus - MLI (1, 21); wykop IV, humus - MLI (4, 11, 12); wykop VIII: humus - MLI (6, 15), ML II (14); wykop X, humus (2); wykop XV, humus - MLI (3); wykop XIII, MLII (7); wykop XVIII: na złożu wtórnym obiektu 372 (19), humus (5); wykop XXI, na złożu wtórnym obiektu 360 (13); wykop 20, MLII (20); wykop 322, ML IV (16, 18); na złożu wtórnym obiektu 325 (8), i obiektu 296 (9); obiekt 372 (10), obiekt 233 (22). Chemiczki, stan. 10. Elementy wydzielone ceramiki KPCW: wykop 20, ML II (17). Rys. J. Kędelska.

Fig. 4. Karczyn, site 21/22. The Late Band Pottery Culture pottery: trench III, humus - MLI (1, 21); trench IV, humus - MLI (4, 11, 12); trench VIII: humus - MLI (6, 15), ML II (14); trench X, humus (2) trench XV, humus - MLI (3); trench XIII, MLII (7); trench XVIII: the secondary deposit in feature 372 (19), humus (5); trench XXI, the secondary deposit in feature 360 (13), trench 20, MLII (20); trench 322, ML IV (16, 18), the secondary deposit in the following features: 325 (8), 296 (9), 372 (10), and (22). Chemiczki, site 10. The Late Band Pottery Culture pottery: trench 20, ML II (17). Drawing by J. Kędelska 


\subsubsection{Makromorfologia}

Klasyfikacji cech makromorfologicznych dokonano w oparciu o schemat L. Czerniaka $^{61}$. Przedstawione ujęcie obejmuje wyłącznie formy zrekonstruowane do stopnia dającego możliwość uzyskania wiarygodnych wskaźników proporcji.

Poniższa tabela zawiera zestawienie technologii, makromorfologii, mikromorfologii i zdobnictwa fragmentów ceramiki wydzielonej KPCW (tab. 10).

Tabela 10. Charakterystyka „późnowstęgowej” ceramiki wydzielonej ze stanowisk diagnostycznych

Table 10. The Late Band Pottery Culture pottery from diagnostic sites

\begin{tabular}{|c|c|c|c|c|c|c|}
\hline Obiekt & Wykop & \begin{tabular}{|c|} 
Typ \\
technologicz- \\
ny
\end{tabular} & $\begin{array}{c}\text { Typ } \\
\text { makromorfo- } \\
\text { logiczny }\end{array}$ & $\begin{array}{c}\text { Typ } \\
\text { mikromorfo- } \\
\text { logiczny }\end{array}$ & Zdobienie & $\begin{array}{l}\text { Uwagi/ } \\
\text { Tablice }\end{array}$ \\
\hline 1 & 2 & 3 & 4 & 5 & 6 & 7 \\
\hline \multicolumn{7}{|c|}{ Chełmiczki, stan. 10 (PET47) } \\
\hline & D3 & IVA/B1 & & $18 \mathrm{e}$ & - & ryc. 5: 7 \\
\hline & \multirow[b]{2}{*}{ D5 } & IVB2/C & & $18 \mathrm{e}$ & nh III-2/25-1.1 & ryc. 5: 14 \\
\hline & & IIIB & & $11 \mathrm{e}$ & $\begin{array}{l}\text { pz III-2/61-1.1 } \\
\text { pz VIII-1/65-1.a }\end{array}$ & ryc. $5: 10$ \\
\hline & \multirow{3}{*}{ D6 } & IVA/B1 & & $18 \mathrm{e}$ & - & ryc. $5: 13$ \\
\hline & & IVB2/C & & $18 \mathrm{e}$ & pz III-2/61-1.1 & ryc. $5: 8$ \\
\hline & & VA & & $3 b$ & - & ryc. $6: 7$ \\
\hline \multirow{13}{*}{139} & \multirow{13}{*}{ D8 } & VA & & $18 \mathrm{e}$ & nh III-2/49k-1.1 & ryc. $6: 2$ \\
\hline & & VA & & $18 \mathrm{~d}$ & - & ryc. $6: 3$ \\
\hline & & IVA/B1 & & $18 \mathrm{e}$ & - & ryc. 5: 9 \\
\hline & & IIIB & & $18 \mathrm{e}$ & pz III-2/49k-1.1 & \multirow{2}{*}{$\begin{array}{l}\text { Jedno } \\
\text { naczynie } \\
\text { ryc. } 6: 1\end{array}$} \\
\hline & & IIIB & & - & bn III-2/61-1.1 & \\
\hline & & IIIB & \multirow[b]{2}{*}{$\mathrm{CI} 3 \mathrm{a}$} & $1 \mathrm{e}$ & - & \multirow{2}{*}{$\begin{array}{l}\text { Jedno } \\
\text { naczynie } \\
\text { ryc. } 7: 1 \\
\end{array}$} \\
\hline & & IIIB & & $3 \mathrm{c}$ & - & \\
\hline & & IVB2/C & & $18 \mathrm{e}$ & pz III-2/65-1.1 & \multirow{2}{*}{$\begin{array}{l}\text { Jedno } \\
\text { naczynie } \\
\text { ryc. 5: } 12\end{array}$} \\
\hline & & IVB2/C & & - & pz VIII-1/65a.1 & \\
\hline & & IVB2/C & & $18 \mathrm{e}$ & pz III-2/61-1.1 & ryc. $5: 6$ \\
\hline & & VA & & $3 b$ & - & \\
\hline & & VA & & $3 d$ & - & ryc. $6: 5$ \\
\hline & & VA & & $3 b$ & - & ryc. $6: 11$ \\
\hline & \multirow[b]{2}{*}{ D17 } & IVA/B1 & \multirow[b]{2}{*}{$\mathrm{CI} 3 \mathrm{~b}$} & $1 \mathrm{k}$ & - & \multirow{2}{*}{$\begin{array}{l}\text { Jedno } \\
\text { naczynie } \\
\text { ryc. } 6: 10\end{array}$} \\
\hline & & \begin{tabular}{|l|} 
IVA/B1 \\
\end{tabular} & & $3 b$ & - & \\
\hline & D18 & IVA/B1 & & $3 b ?$ & - & ryc. $6: 9$ \\
\hline & \multirow{4}{*}{ D20 } & IIIB & & $18 \mathrm{e}$ & pz III-2/61-1.1 & ryc. $4: 17$ \\
\hline & & IIIB & & $18 \mathrm{e}$ & pz III-2/49f-1.1 & ryc. $4: 20$ \\
\hline & & VA & & - & bn VIII-1/87p.3 & ryc. $6: 4$ \\
\hline & & VB & & - & bn VIII-1/109p.3 & ryc. $6: 6$ \\
\hline
\end{tabular}

${ }^{61}$ Czerniak 1980, s. 49-62. 
cd. tab. 10

\begin{tabular}{|c|c|c|c|c|c|c|}
\hline 1 & 2 & 3 & 4 & 5 & 6 & 7 \\
\hline & \multirow{6}{*}{ D20 } & VB & & - & bn VIII-1/109a.4 & ryc. $5: 15$ \\
\hline & & VA & & - & bx VIII-1/109a.4 & ryc. 5: 11 \\
\hline & & VA & & $27 \mathrm{c} ?$ & - & ryc. $6: 8$ \\
\hline & & VA & & $27 \mathrm{~b}$ & - & ryc. $5: 3$ \\
\hline & & VB & & $27 \mathrm{c}$ & - & ryc. $6: 12$ \\
\hline & & VA & & $27 \mathrm{~b}$ & - & \\
\hline \multicolumn{7}{|c|}{ Karczyn, stan. 21/22 (PET 30) w obrębie wycinka A } \\
\hline & \multirow{2}{*}{ IIIb } & IVB2/C & & $11 \mathrm{e}$ & - & ryc. $4: 21$ \\
\hline & & IIIB & & - & bx VII-2/1h-n.4 & ryc. $4: 1$ \\
\hline & \multirow{3}{*}{$\mathrm{IVb}$} & IIIB & & $11 \mathrm{e}$ & & ryc. 4: 12 \\
\hline & & IIIB & & - & $\begin{array}{l}\text { bx III-1/1h-n.4 } \\
\text { bx VIII-2/1-1 }\end{array}$ & ryc. 4: 11 \\
\hline & & IIIB & & - & bx IX-5/1-n.4 & ryc. 4: 4 \\
\hline & \multirow{3}{*}{ VIII } & IVB2/C & & $18 \mathrm{e}$ & - & ryc. $4: 14$ \\
\hline & & IVA/B1 & & - & pb III-2 & ryc. $4: 15$ \\
\hline & & IIIB & & - & bx VIII-2/1e-x.6 & ryc. $4: 6$ \\
\hline & \multirow{2}{*}{$\mathrm{XVa}$} & IIIB & & $18 \mathrm{e}$ & - & ryc. 5: 2 \\
\hline & & IVB2/C & & $1 \mathrm{~d}$ & - & ryc. 5: 5 \\
\hline & $\mathrm{Xb}$ & IIIB & & - & bx IX-5/1-n.4 & ryc. $4: 2$ \\
\hline & \multirow{4}{*}{ XIIIIa } & IIIB & & - & \begin{tabular}{|l|l} 
pz III-2/1G-1.4 \\
bn VII-2/1g-n.4 \\
\end{tabular} & \multirow{2}{*}{$\begin{array}{l}\text { Jedno } \\
\text { naczynie } \\
\text { ryc. } 4: 8\end{array}$} \\
\hline & & IIIB & & $11 \mathrm{e}$ & bn VII-2/1g-n.4 & \\
\hline & & IIIB & & - & bx III-2/1g-n.4 & ryc. 4: 7 \\
\hline & & IIIB & & $1 \mathrm{e}$ & pz III-2/1g-n.4 & ryc. $4: 9$ \\
\hline & $\mathrm{XVa}$ & IIIB & & $1 \mathrm{c}$ & $\begin{array}{l}\text { pz III-2/49f-1.1 } \\
\text { bn VII-2/1h-n.4 }\end{array}$ & ryc. $4: 3$ \\
\hline & \multirow{3}{*}{ XVIIIa } & IIIB & & $11 \mathrm{e}$ & pz III-2/61-1.1 & ryc. 4: 19 \\
\hline & & IIIB & & - & bx VII-2/1g-n. 4 & ryc. $4: 5$ \\
\hline & & IIIB & & - & bx III-2/1g-n.4 & ryc. $4: 10$ \\
\hline & $\mathrm{XXb}$ & IIIB & & $11 \mathrm{e}$ & - & \begin{tabular}{|l|} 
ryc. $4: 13$ \\
\end{tabular} \\
\hline \multicolumn{7}{|c|}{ Karczyn, stan. 21/22 (PET 30) w obrębie wycinka B } \\
\hline 216 & $70 \mathrm{a}$ & VA & & $18 \mathrm{j}$ & - & ryc. $5: 1$ \\
\hline \multirow[t]{4}{*}{232} & $69 \mathrm{~b}$ & VA & & - & bx VIII-1/109-n.3 & ryc. $4: 22$ \\
\hline & $322 \mathrm{~b}$ & IIIB & & $18 \mathrm{e}$ & - & ryc. $4: 16$ \\
\hline & & & & & & \\
\hline & & VA & & - & bx III-2/61-1.1 & ryc. $4: 18$ \\
\hline 317 & 326 & IIIB & & $9 \mathrm{~d}$ & - & ryc. 5: 4 \\
\hline \multicolumn{7}{|c|}{ Olszewice, stan. 7 (PET18a) } \\
\hline \multirow{6}{*}{9} & \multirow{6}{*}{9} & IVB2/C & & $11 \mathrm{e}$ & pz III-2/62-1.1 & ryc. $7: 4$ \\
\hline & & VB & & $18 \mathrm{e}$ & pz III-2/62-1.1 & ryc. $7: 3$ \\
\hline & & VA & & - & bx VIII-1/109a & ryc. $7: 10$ \\
\hline & & VB & & $3 b$ & bd III-2/49e-1.1 & ryc. $7: 8$ \\
\hline & & VB & & $18 \mathrm{e}$ & pz III-2/61-1.1 & ryc. $7: 6$ \\
\hline & & IIIB & & $18 \mathrm{e}$ & pz III-2/61-1.1 & ryc. $7: 5$ \\
\hline 10 & 9 & VA & & - & bx VIII-1/65a1 & ryc. $7: 2$ \\
\hline
\end{tabular}



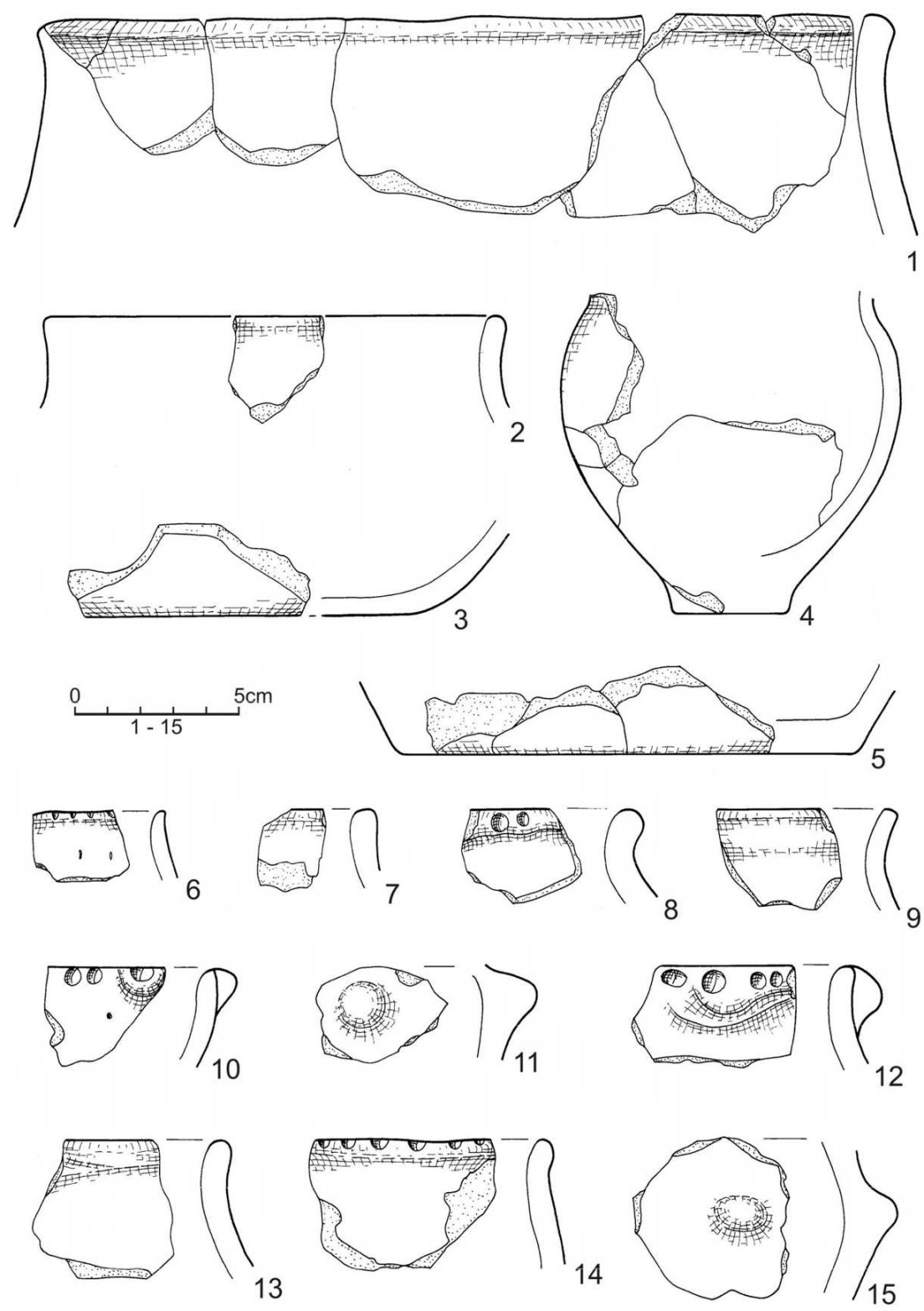

Ryc. 5. Karczyn, stan 21/22. Elementy wydzielone ceramiki KPCW: obiekt 216 (1); obiekt 317 (4); wykop XV, humus - ML I $(2,3,5)$. Chemiczki, stan. 10. Elementy wydzielone ceramiki KPCW: wykop 3, MLII (7), wykop 5, ML II (14), wykop VI, ML II (8, 13); wykop VIII: ML II (6, 10, 12), ML IV (9); wykop XX, ML II $(11,15)$. Rys. J. Kędelska

Fig. 5. Karczyn, site 21/22. The Late Band Pottery Culture ceramics: feature 216 (1), feature 317 (4); trench XV, humus - ML I $(2,3,5)$. Chemiczki, site 10. The Late Band Pottery Culture ceramics: trench 3, MLII (7), trench 5, ML II (14), trench VI, ML II $(8,13)$; trench VIII: ML II $(6,10,12)$, ML IV (9 ); trench XX, ML II $(11,15)$. Drawing by J. Kędelska 

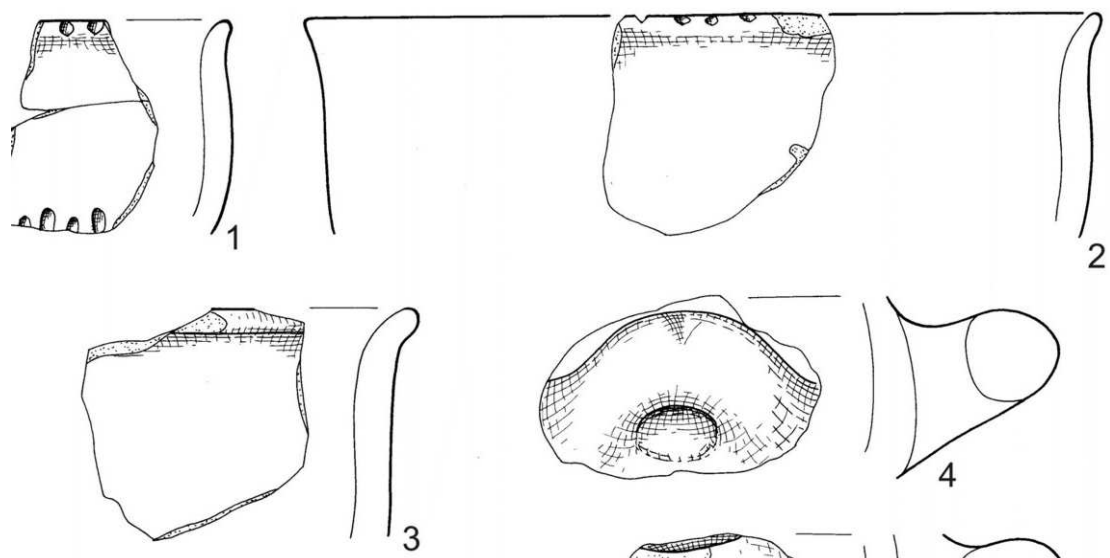

$$
2
$$
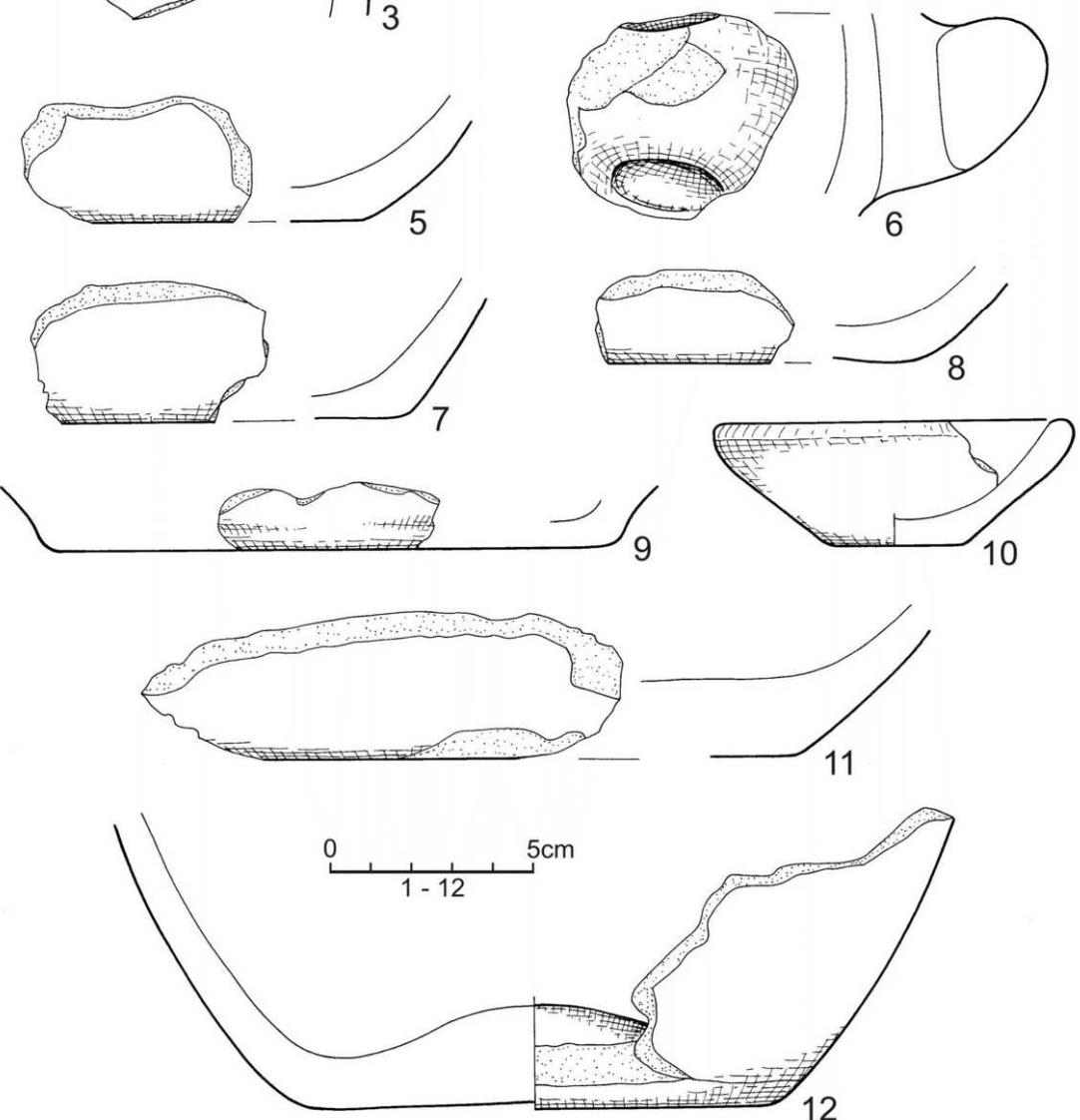

Ryc. 6. Chemiczki, stan. 10. Elementy wydzielone ceramiki KPCW: wykop 6: ML I (7), ML II (5); wykop 8: ML IV (2, 3), ML V (1, 8, 11); wykop 17, ML II (10); wykop 18, ML II (9); wykop 20, ML II $(4,6,12)$. Rys. J. Kędelska

Fig. 6. Chemiczki, site 10. The Late Band Pottery Culture pottery: trench 6: ML I (7), ML II (5); trench 8: ML IV $(2,3)$, ML V $(1,8,11)$; trench 17, ML II $(10)$; trench 18, ML II (9), trench 20, ML II $(4,6,12)$. Drawing by J. Kędelska 

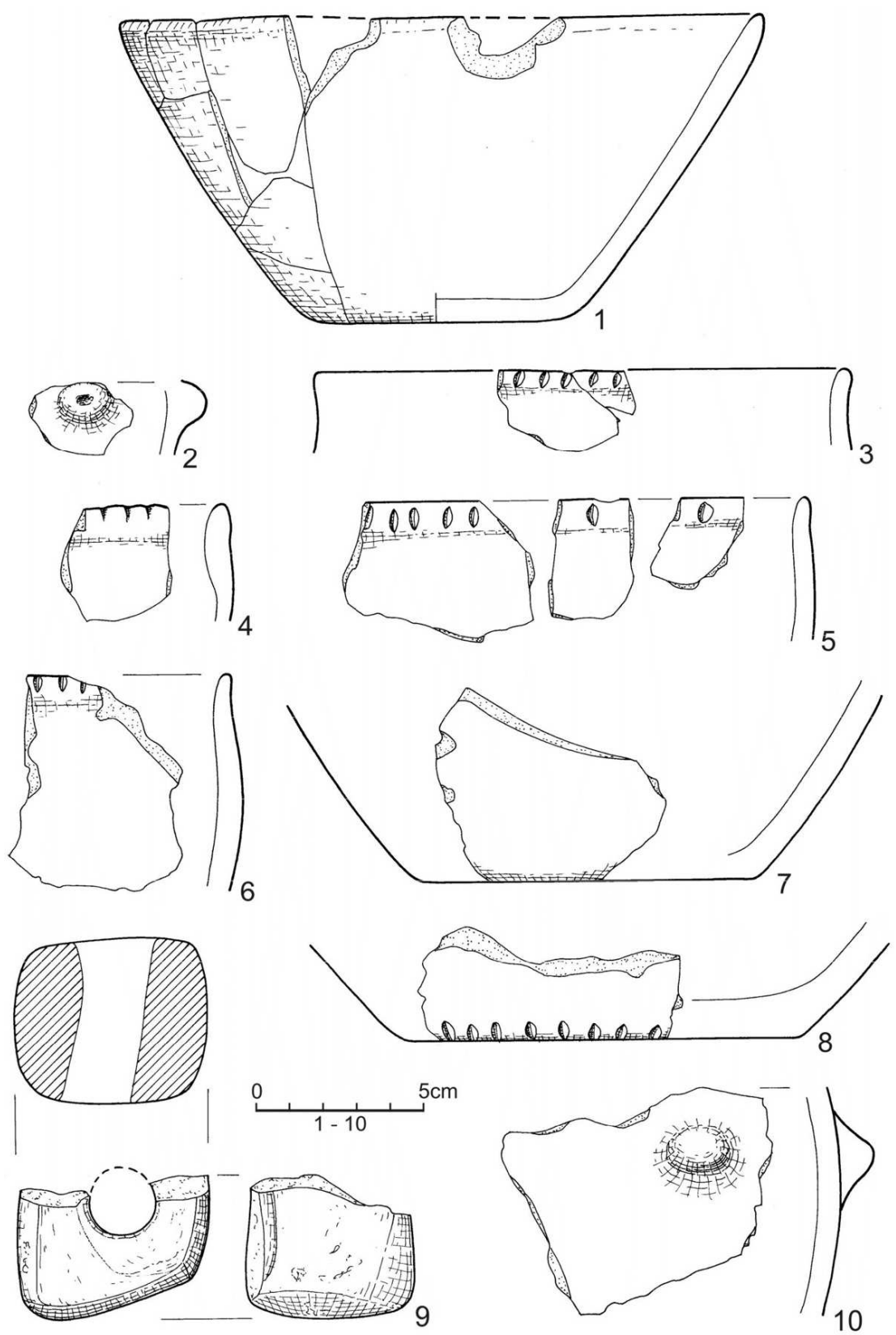

Ryc. 7. Chemiczki, stan. 10. Elementy wydzielone ceramiki KPCW: obiekt 139 (1). Olszewice, stan. 7. Elementy wydzielone ceramiki KPCW: obiekt 9: ML I (4, 7, 8, 9, 10), ML II (5, 6); obiekt 10: ML I (3), ML II (2). Rys. J. Kędelska

Fig. 7. Chemiczki, site 10. The Late Band Pottery Culture pottery: feature 139 (1). Olszewice, site 7 The Late Band Pottery Culture pottery: feature 9: ML I (4, 7, 8, 9, 10), ML II (5, 6), object 10: ML I (3), ML II (2). Drawing by J. Kędelska 
- Wśród form diagnostycznych na stanowisku Chemiczki 10 znalazły się dwie misy opisane jako typ bazowy CI, określone jako typy szczególne: $3 b$ (ryc. 6: 10) i 3a (ryc. 7: 1). Naczynia te należą do typów „dynamicznych”, czyli operatywnych z punktu widzenia analizy chronologicznej.

- Naczynie z Karczyna, stan. 21/22 zarejestrowane w ramach wycinak B, pochodzi z obiektu KPCW numer 317 (ryc. 5: 4). Słaby stan zachowania tej formy nie pozwala na jej rekonstrukcję, która umożliwiła by bardziej szczegółową jej klasyfikację wychodzącą poza kategorię typu bazowego - garnka.

- Na stanowisku Olszewice 7 nie zarejestrowano form, na podstawie których możliwe było uzyskanie wskaźników proporcji.

\subsubsection{Mikromorfologia}

Oznaczeń w dziedzinie mikromirfologii dokonano na podstawie stosowanych schematów typologii krawędzi i den naczyń ${ }^{62}$. Całość uzyskanych informacji zaprezentowano w tabeli 10 .

- Na stanowisku 10 w Chemiczkach analizie poddano 17 fragmentów krawędzi oraz 11 fragmentów den. Pośród krawędzi największa frekwencja cechuje typy wychylone na zewnątrz (18) lub do wnętrza naczynia (11) ze zwieńczeniami niemającymi grani (typ e). Do pojedynczych przypadków należą wylewy o zwieńczeniu z jedną lub dwoma graniami. Wśród den dominują typy 3 i 27 o różnych proporcjach grubości dna do ścianki naczynia.

- W Karczynie, stan. 21/22 w ramach wycinka A zarejestrowano 9 fragmentów wylewu typu 11 i 18 ze zwieńczeniem w typie e, w jednym przypadku odnotowano wylew o prostym układzie ścianek i zwieńczeniu z jedną granią (ryc. 4: 3). Jedyny odkryty fragment dna zaklasyfikowano do typu 1d (ryc. 5: 5).

- W obrębie wycinka B stan. 21/22 w Karczynie odnotowano jeden fragment wylewu 11e oraz 6 fragmentów wylewu jednego naczynia o krawędzi wychylonej na zewnątrz ze zwieńczeniem z dwoma graniami (ryc. 5: 1). Jedyny zlokalizowany fragment dna o cechach naczynia na stópce zaklasyfikowany jako forma $1 \mathrm{~d}$ pochodzi (ryc. 5: 5).

- W Olszewicach, stan 21/22 udokumentowano 7 fragmentów wylewu w typie 18 e i 11 e należących do 4 naczyń oraz fragment zdobionego dna w typie $3 b$ (ryc. 7: 8).

\subsubsection{Zdobnictwo}

Klasyfikacja cech zdobnictwa dokonana została na podstawie schematu zaproponowanego przez L. Czerniaka ${ }^{63}$.

\footnotetext{
${ }^{62}$ Czebreszuk, Kośko, Szmyt 2006, s. 55-57.

${ }^{63}$ Czerniak 1980, s. 25-49.
} 
- Na stanowisku 10 w Chełmiczkach udział ceramiki zdobionej wynosi 5,63\% całego zbioru ceramiki KPCW. W przeważającej ilości są to wątki zdobnicze związane z ,karbowaniem” krawędzi wylewu. W jednym przypadku zarejestrowano zdobienie dwustrefowe: strefy podkrawędnej zewnętrznej oraz osobny wątek lokalizowanym w strefie brzuśca (ryc. 6: 1). Do zdobień plastycznych zaliczono dwa guzki (ryc. 5: 11, 15) oraz dwa ucha (ryc. 6: 4, 6). Całość ceramiki zdobionej została zarejestrowana w obrębie warstwy z wykopów.

- W Karczynie, stan. 21/22 w obrębie wycinka A zarejestrowano 14 fragmentów zdobionych $(13,59 \%)$, wszystkie pochodzą z warstw mechanicznych eksplorowanych w ramach wykopów oraz z wypełnisk późniejszych obiektów. Wśród tego zbioru znajduje się jeden ,karbowany” fragment wylewu (ryc. 4: 19) oraz fragment brzuśca zdobiony odciskami owalnego stempla (ryc. 4: 15), pozostałą część zbioru stanowi ceramika zdobiona ornamentyka „kłutą” (ryc. 4: 1-11).

Wśród zespołu tej ceramiki wyróżniono wątki zbudowane z elementów jednorodnych pod względem formy i wielkości, wykonane w technice „,kłutej” o stęplach owalnych i podłużnych oraz odciskach w formie połączonych trójkątów ${ }^{64}$ (ryc. 4: 11). Brak możliwości rekonstrukcji większych fragmentów naczyń, oraz związane z tym rozdrobnienie materiału utrudniają korespondencję wątków zdobniczych względem stref zdobienia. Zapewne w przeważającej części były to wątki o przebiegu horyzontalnym i diagonalnym w układzie płaszczyznowym, W jednym przypadku możliwe jest wystąpienie zdobienia mającego na celu podkreślenie tektoniki naczynia.

- Na stanowisku Karczyn 21/22 w ramach wycinka B zaobserwowano dwa fragmenty ceramiki zdobionej odciskami owalnego stempla. Jest to fragment pochodzący ze strefy brzuśca oraz część „karbowanego” wylewu. Do zdobień plastycznych zaliczono ucho z obiektu 232 (ryc. 4: 22).

- Z Olszewie, stan. 7 pochodzi dziesięć elementów zdobionych $(7,86 \%)$, są to dwa guzki ze strefy brzuścowej dwóch naczyń (ryc. 7: 2, 10), siedem fragmentów „karbowanych" krawędzi należących do czterech naczyń (ryc. 7: 3 -6) oraz fragment dna naczynia zdobiony odciskami owalnego stempla w strefie przydennej (ryc. 7: 8). Całość ceramiki ornamentowanej pozyskano z wypełnisk dwóch obiektów: jeden fragment pochodzi z obiektu 10, a pozostałe z obiektu 9.

\subsubsection{Informacje archeozoologiczne}

Ta część pracy oparta została na wynikach analiz wykonanych przez A. Marcinia$\mathrm{ka}^{65}$. Poniższe rozważania stanową próbę prezentacji jedynie wybranych aspektów specyfikacji, dokonanej na podstawie specjalistycznej bazy analitycznej. Kompleksowa

\footnotetext{
${ }^{64}$ Zdobienie „rösseńskie” (Czerniak 1978, 2008).

${ }^{65} \mathrm{~W}$ tym miejscu pragnę serdecznie podziękować prof. dr. hab. Arkadiuszowi Marciniakowi za udostępnienie wyników analizy szczątków kostnych ze stanowisk ,diagnostycznych”.
} 
ocena szczątków, dająca możliwość wielowymiarowej interpretacją, ma zdecydowanie szerszą wymowę poznawczą niż zostało to przedstawione poniżej.

Szczegółowemu określeniu poddano 211 fragmentów kości zwierzęcych pochodzących z obiektów osadowych. Kolejno były to: dla Chełmiczek 10 obiekt 144, Karczyna 21/22 obiekty: 97, 232, 386 i 371, a dla stan. 7 w Olszewicach obiekty: 3, 5, 9 i 10.

Tabela 11. Chełmiczki, stan. 10; Olszewice, stan. 18; Karczyn, stan. 21/22. Zwierzęce szczątki kostne z obiektów „późnowstęgowych” (wg Marciniak 2008)

Table 11. Chełmiczki, site 10; Olszewice, site 18; Karczyn, site 21/22. Animal skeletal remains from the Late Band Pottery Culture features (by Marciniak 2008)

\begin{tabular}{|c|c|c|c|c|c|c|c|c|c|c|c|}
\hline Obiekt & $\begin{array}{c}\text { Poziom } \\
\text { eksploracji }\end{array}$ & $\begin{array}{l}\text { Wiel- } \\
\text { kość } \\
\text { owca/ } \\
\text { koza }\end{array}$ & $\begin{array}{c}\text { Owca/ } \\
\text { koza }\end{array}$ & $\begin{array}{l}\text { Wiel- } \\
\text { kość } \\
\text { świni }\end{array}$ & Świnia & $\begin{array}{l}\text { Wiel- } \\
\text { kość } \\
\text { bydła }\end{array}$ & Bydło & $\begin{array}{c}\text { Wiel- } \\
\text { kość } \\
\text { zająca/ } \\
\text { średnie- } \\
\text { go psa }\end{array}$ & $\begin{array}{l}\text { Nieozna- } \\
\text { czone }\end{array}$ & $\mathrm{I} / \mathrm{W}$ & Uwagi \\
\hline \multicolumn{12}{|c|}{ Chełmiczki stan. 10} \\
\hline \multirow{3}{*}{144} & WMVII & 2 & - & - & - & 3 & 2 & - & 2 & 0,068 & $\begin{array}{l}5 \text { fr. zębów } \\
\text { mlecznych } \\
\text { bydła }\end{array}$ \\
\hline & WMVIII & 9 & - & 7 & 1 & 9 & 4 & - & 13 & 0,149 & $\begin{array}{l}\text { Kości czę- } \\
\text { ściowo } \\
\text { zwęglone }\end{array}$ \\
\hline & WMIX & - & - & - & - & - & 2 & 1 & 1 & 0,103 & \\
\hline \multicolumn{2}{|l|}{ SUMA } & 11 & 0 & 7 & 1 & 12 & 8 & 1 & 16 & 56 & \\
\hline \multicolumn{2}{|l|}{$\%$} & 19,64 & 0 & 12,50 & 1,79 & 21,42 & 14,29 & 1,79 & 28,57 & 100 & \\
\hline \multicolumn{12}{|c|}{ Olszewice stan. $18 \mathrm{a}$} \\
\hline 3 & WMI & - & - & - & - & 16 & 6 & - & 3 & 0,082 & \\
\hline 5 & WMI & - & - & - & - & 2 & 2 & - & - & 0,308 & $\begin{array}{l}\text { Ślady nadpa- } \\
\text { leń }\end{array}$ \\
\hline \multirow[t]{2}{*}{9} & WMI & 12 & 7 & - & 5 & 8 & 15 & - & 10 & 0,040 & $\begin{array}{l}\text { Ślady raba- } \\
\text { nia }\end{array}$ \\
\hline & WMII & 1 & 2 & - & - & 4 & 1 & - & 4 & 0,203 & \\
\hline 10 & WMII & 2 & - & - & - & 1 & 6 & - & 1 & 0,115 & $\begin{array}{l}\text { Znaczne } \\
\text { zwapnienie } \\
\text { kości }\end{array}$ \\
\hline \multicolumn{2}{|l|}{ SUMA } & 15 & 9 & 0 & 5 & 31 & 30 & 0 & 18 & 108 & \\
\hline \multicolumn{2}{|l|}{$\%$} & 13,89 & 8,33 & 0 & 4,63 & 15 & 27,78 & 0 & 16,67 & 100 & \\
\hline \multicolumn{12}{|c|}{ Karczyn stan. 2122} \\
\hline 97 & WNII-calec & - & - & - & - & 2 & 19 & - & 10 & 0,093 & \\
\hline 232 & WNII-calec & - & - & - & - & 1 & - & - & 7 & 0,267 & \\
\hline 371 & WNII-calec & - & - & - & - & - & 2 & - & 3 & 0,357 & $\begin{array}{l}\text { Nacięci } \\
\text { pokonsump- } \\
\text { cyjne }\end{array}$ \\
\hline 386 & WNII-calec & - & - & - & - & 3 & - & - & - & 0,500 & $\begin{array}{l}\text { Ślady wy- } \\
\text { gładzani - } \\
\text { półfabrykat? }\end{array}$ \\
\hline \multicolumn{2}{|l|}{ SUMA } & 0 & 0 & 0 & 0 & 6 & 21 & 0 & 20 & 47 & \\
\hline \multicolumn{2}{|l|}{$\%$} & 0 & $\mathbf{0}$ & 0 & 0 & 12,77 & 44,68 & 0 & 42,55 & 100 & \\
\hline
\end{tabular}


Zestawienie informacji na temat składu gatunkowego na poszczególnych stanowiskach zawart w tabeli 11. Rozpoznane szczątki pochodzą od ssaków domowych reprezentowanych przez: bydło (108 fragmentów ${ }^{66}-51,18 \%$ ), owcę/kozę (35 fragmentów - 16,59\%) oraz świnię (13 fragmentów - 6,16\%). Na stanowisku 7 w Olszewicach w obrębie obiektu 10 stwierdzono wystąpienie kości pochodzących od rosłych osobników należących do bydła turzego.

Wśród identyfikowanych szczątków przeważają fragmenty, których zachowana wielkość w stosunku do całości kości nie przekracza 1/4 (77,25\%). Na dalszych miejscach lokują się zachowane w przedziale $1 / 4-1 / 2(9,00 \%), 1 / 2$ a $3 / 4(8,06 \%)$ oraz powyżej $3 / 4$ $(3,32 \%)$. Zaledwie 5 fragmentów opisano jako przedstawiające wielkość kompletną, co stanowi $2,37 \%$ całości zbioru.

$\mathrm{Na} 161$ fragmentach odnotowano wystąpienie złamań, przy czym w 119 przypadkach były to złamania przeddepozycyjne, w 32 złamanie dotyczyło w większości działań przeddepozycyjnych, a częściowo tylko współczesnych; w 10 przypadkach większość uszkodzeń określono jako współczesne. Odnośnie do 5 fragmentów pochodzących z omawianego zbioru odnotowano wystąpienie nadpaleń lokalizowanych na trzonie kości.

W Olszewicach w obiekcie 9 na 2 fragmentach kości udowej bydła zarejestrowano charakterystyczne poprzeczne ślady rąbania mającego na celu dotarcie do jamy szpikowej. W obiekcie 386 z Karczyna, stan. 21/22 zidentyfikowano kość długą bydła ze śladami wygładzania, mogącą być półfabrykatem narzędzia.

\section{CHRONOLOGIA}

Prezentowana niżej systematyka chronologiczna materiałów KPCW opracowana została w nawiązaniu do periodyzacji okresu środkowego neolitu na Kujawach autorstwa L. Czerniaka ${ }^{67}$. Na podstawie materiałów nie można przeprowadzić redefinicji - konkretyzacji omawianego schematu, a ich datowanie ograniczone jest do nawiązań względem wytyczonych ram - przedziałów chronologicznych przedstawionych w tym układzie ${ }^{68}$.

\subsection{Chronologia względna}

Chronologia względna ceramiki KPCW została ustalona po analizie jakościowoilościowej, przez porównanie uzyskanych wyników z zestawieniami „wzorcowymi” dla datowania technologicznego i stylistycznego w odniesieniu do kujawskiej periodyzacji $\mathrm{KPCW}^{69}$.

\footnotetext{
${ }^{66}$ Łącznie potraktowano kategorie określające gatunek oraz szczątki odpowiadające mu wielkością.

${ }^{67}$ Czerniak 1994.

${ }^{68}$ Czerniak 1994, ryc. 2.

${ }^{69}$ Por. w wersji wyjściowej Czerniak 1980.
} 
Chełmiczki, stan. 10. Algorytm datowania technologicznego na poziomie gt ujawnia zbieżność badanej struktury technologicznej z zespołem z Broniewic, stan. 1 datowanym na fazę IIIb. Najwięcej podobieństw w rozkładzie poszczególnych grup wykazuje zbiór z obiektu 182. Jednak znaczne różnice rejestrowane są na niższym poziomie analizy frekwencji egt. Dotyczą one wystąpienia w zbiorze z Broniewic ceramiki grupy IIIA, której brak na stanowisku w Chełmiczkach oraz znacznych odmienności w proporcjach rozkładu grupy VB, która w Chełmiczkach przekracza 16\%, natomiast w Broniewicach wynosi zaledwie 1,5\%. Na podstawie wyniku można zaakceptować datowanie zbioru na fazę III, z zastrzeżeniami o zakłóceniu związanym z hipotetyczną ahomogennością.

Przeprowadzając analizę porównawczą grubości ścianek naczynia, na podstawie odniesień do wyników ze stanowiska 3 w Kruszy Zamkowej ${ }^{70}$, można zaklasyfikować badany zbiór do fazy IIIb, co potwierdza wcześniejsze wyniki.

W dziedzinie makromorfologii zrekonstruowane zostały dwie misy typ CI3b oraz CI3a według typologii L. Czerniaka ${ }^{71}$, które posiadają swoje odpowiedniki na stanowiskach w Kościelcu Kujawskim 16; Brześciu Kujawskim 4 oraz Kruszy Zamkowej 3, gdzie łączone są z osadnictwem KPCW fazy IIb-IIIc.

Karczyn, stan. 21/22 - wycinek A. Za pomocą datowania technologicznego tej części stanowiska wykazano frekwencję zbadaną na poziomie gt utrzymującą się we wskaźnikach opisanych dla fazy I KPCW. Wyróżnia ją wysoki udział gt IIIB (66,99\%) oraz niski udział grupy V. Na omawianym etapie analizy można przyrównać tę strukturę do zespołu z Jankowa, stan. 1, ob. 15. Główne rozbieżności dotyczą poziomu egt i objawiają się absencją grupy IIIA, która w Jankowie stanowi 46\% zbioru, oraz wysokim udziałem egt IVB2/C, która w obiekcie z Jankowa nie została zdiagnozowana.

Stwierdzona niezgodność opisanego stanu technologicznego w stosunku do rekonstruowanych systemów pozwala wnioskować o wystąpieniu jego zakłócenia zarówno w sensie ograniczonej skali jego rozpoznania, jak i hipotezy ahomogenności. Przyjęcie powyższych założeń prowadzi do konieczności wyróżnienia dwóch poziomów osadnictwa „późnowstęgowego”, obejmującego badaną część stanowiska: związanego z ceramiką „kłutą” oraz reprezentowaną przez ceramikę nie zdobioną ornamentem „kłutym”, zsynchronizowaną z chatą trapezowatą.

\subsubsection{Ceramika „kłuta”}

„Kłutą” fazę zasiedlenia reprezentuje zbiór 24 fragmentów ceramiki, w tym 12 zdobionych tym ornamentem, w całości zaliczony do gt IIIB i reprezentujący klasę naczyń cienkościennych. Cały kompleks przedstawionych źródeł pochodzi z warstwy humusu,

\footnotetext{
${ }^{70}$ Czerniak 1980, tab. 3.

${ }^{71}$ Czerniak 1980, s. 49-56.
} 
która w obrębie stanowiska podlegała współczesnym przemieszczeniom. Dwa fragmenty zarejestrowano w obrębie obiektów na złożu wtórnym.

Bardziej szczegółowego datowania w ramach chronologii względnej dokonać można jedynie z wyzyskaniem analizy zdobnictwa, gdyż na podstawie posiadanego zbioru nie można zrekonstruować form do poziomu oceny makromorfologicznej. Szansa oceny pozycji chronologicznej rysuje się przez odniesienie do dwóch systemów klasyfikacji: śląsko-czeskiego oraz kujawskiego.

\subsubsection{Odniesienie do systemu „śląsko-czeskiego”}

Chronologia względna KCWK na terenie Śląska, usystematyzowana przez W. Wojciechowskiego $^{72}$ ujęta została $\mathrm{w}$ dwie fazy rozwojowe z podokresami (faza I, IIa i IIb), synchronizowanymi z fazami III-IV/V w systematyce zaproponowanej przez M. Zápotocką $^{73}$ odnosnie do materiałów czeskich. Na schemacie nie uwzględniono konieczności jego redefinicji związanej z późniejszymi odkryciami na terenie Dolnego Śląska stadiów przejściowych od fazy szareckiej KCWR do wczesnej KCWK (Wojciechowski 1976).

W ujęciu W. Wojciechowskiego ceramika „kłuta” na obszarze Kujaw pojawia się w śląskiej fazie IIa (IV w periodyzacji czeskiej). Ze względu na ubogie przesłanki stylistyczne oraz zupełny brak danych o makromorfologii, zestaw cech, którymi dysponujemy daje możliwość ogólnego odniesienia zbioru do śląskiej fazy IIa, odpowiadającej czeskiej fazie IV.

\subsubsection{Odniesienie do systemu kujawskiego}

Kontekst periodyzacji kujawskiej stanowi możliwość pewnego zawężenia ram czasowych tego zjawiska. Opiera się ono na stwierdzeniu występowania w ramach IV fazy czeskiej KCWK, form zdobień pochodzących ze strefy kultury rösseńskiej ${ }^{74}$.

Spostrzeżenie to $\mathrm{w}$ analizowanym materiale dotyczy fragmentu zdobionego podwójnym odciskiem stempla w przybliżeniu trójkątnego, w układzie płaszczyznowym. Taka forma zdobień zaliczana jest do wątków typowo „,össeńskich”,75. Pozwala to na odniesienie analizowanego zbioru do materiałów z Konar, stan. 20 datowanego na fazę I $\mathrm{KPCW}^{76}$. Analogiczna forma zdobień zarejestrowana została też na stanowisku 1 w Gustorzynie ${ }^{77}$. Jest to fragmentarycznie zachowana amfora zdobiona, według autora

\footnotetext{
${ }^{72}$ Wojciechowski 1970.

${ }^{73}$ Zápotocká 1970.

${ }^{74}$ Wojciechowski 1970, s. 39.

${ }^{75}$ Czerniak 1978, s. 37, ryc. 9-ł.

${ }^{76}$ Czerniak 1978.

${ }^{77}$ Grygiel 1996, s. 93, ryc. 5, 6.
} 
w stylu nawiązującym do rösseńskiego, pochodząca z obiektu 1 datowanego metodą C14 na $3790 \pm 140$ bc $(4650 \pm 350 \mathrm{BC})$. Data mieści się w przyjętych przedziałach czasowych dla fazy I KPCW.

\subsubsection{Ceramika „brzeska”}

Pozostała część zbioru ceramiki z Karczyna w części A, po przyjęciu tezy o niehomogenności tego zbioru pod względem cech technologicznych i stylistycznych, może być datowana względnie jedynie przez odniesienie do rejestrowanej konstrukcji chaty trapezowatej. Założenie to, przy uwzględnieniu zastrzeżeń związanych z jego rekonstrukcją, może być zaklasyfikowane do typu budowli o konstrukcji ścian bocznych opartych na słupach gęsto rozlokowanych w rowach fundamentowych, o ciągłym przebie$\mathrm{gu}^{78}$. Uzyskana klasyfikacja pozwala przyporządkować tę budowlę konstrukcjom charakterystycznym dla fazy IIb-IIIc KPCW.

\section{Karczyn, stan. 21/22 - wycinek B}

W obrębie tej części stanowiska jedynym efektywnym sposobem datowania względnego jest technologia, gdyż zestaw cech stylistycznych nie pozwala na bardziej szczegółowe wnioski niż tylko odnoszące się do taksonomii kulturowej.

Datowanie cech technologicznych pozwala ulokować badany zbiór w obrębie fazy IIIb w odniesieniu do wzorcowego zestawu frekwencji cech struktury technologicznej. Najbliższe analogie znajduje w strukturze obiektu 12 ze stanowiska $1 \mathrm{w}$ Broniewicach. Rejestrowana zgodność składników gt nie potwierdza się na poziomie analizy egt. Dotyczy to obecności egt IIIA w zespole z Broniewa $(6,4 \%)$ i jej absencji w zespole z Karczyna. Jednak duża zbieżność pozostałych wyznaczników technologicznych w odniesieniu do zespołu wzorcowego pozwala zaakceptować uzyskaną chronologię na poziomie fazy IIIb oraz wnioskować o wzajemnym powiązaniu funkcjonalno-chronologicznym tej części stanowiska z chatą trapezowatą i obiektami KPCW zarejestrowanymi w części A.

\section{Olszewice, stan. 7}

Chronologię względną stanowisk w Olszewicach, na podstawie wyników datowania technologicznego określono na fazę IIIa. Analizowany zbiór wykazuje zgodność ze wzorcową strukturą technologiczną zespołu z Kruszy Zamkowej, stan. 3, obiekt 636, na poziomie gt. W zakresie egt rejestrowane są dość duże odchylenia w proporcji poszcze-

\footnotetext{
${ }^{78}$ Czerniak 1980, s. 115-118.
} 
gólnych cech, co prowadzi do wniosku o prawdopodobnym zakłóceniu możliwości oceny chronologicznej tego zbioru poprzez jego ahomogenności i ograniczony zakres rozpoznania stanowiska. Charakterystyka struktury technologicznej wykonana oddzielnie odnośnie do obiektów 9 i 10 (tab. 9) oraz wszystkich obiektów „późnowstęgowych” $\mathrm{z}$ tego stanowiska (tab. 8) pozwala wnioskować o ich wzajemnej współczesności.

W zakresie datowania stylistycznego, pewne możliwości uzyskania relacji chronologicznej daje ornamentowany fragment dna. Rejestrowana strefa zdobień (bd), w odniesieniu do zbioru ceramiki analizowanej przez L. Czerniaka ${ }^{79}$ nie jest odnotowana. Wykorzystanie wzmiankowanej strefy do umieszczenia nacinanego „karbowania” udokumentowane zostało w Brześciu Kujawskim na stan. $3^{80}$, jak również w Brześciu Kujawskim na stanowisku $4^{81}$, gdzie akcentowana strefa, na nieco odmiennej formie dna, lączona z obiektem 892, datowana jest metodą ${ }^{14} \mathrm{C}$ na $3450 \pm 190$ bc $(4250 \pm 475 \mathrm{BC})$, wpisując się w ramy chronologiczne fazy IIIa KPCW.

Obecne na stanowisku, rejestrowane wycinkowo, budowle trapezowate, $\mathrm{z}$ racji niepełnej ujawnionej ich konstrukcji ścian bocznych, która w kryteriach ciągłości i nieciągłości rowów fundamentowych ma decydujące znaczenie przy ich chronologizacji oraz niewielką ilości bardzo zniszczonej ceramiki pozyskanej z rowów, nie mogą stanowić przesłanek ,pomocniczych” przy datowaniu względnym.

\subsection{Chronologia bezwzględna}

Dla badanych stanowisk diagnostycznych dysponujemy tylko dwoma oznaczeniami radiowęglowymi, wykonanymi na próbkach kości zwierzęcych. Pochodzą one ze stanowiska 7 w Olszewicach. Wykonane zostały dla obiektu 9: Kiev - 14680 (4890 \pm 80 BP; $3750 \pm 230$ BC) oraz obiektu 10: Kiev - 14681 (4960 \pm 80 BP; $3800 \pm 170$ BC). Kalibrację wyników analizy przeprowadzoną na podstawie programu OxCal V.3.10 przedstawiono na ryc. 8,9 oraz wykresach 1 i 2.

Wcześniejsza diagnoza technologiczno-stylistyczna chronometrii tych obiektów pozostaje zgodna $\mathrm{z}$ wynikami datowania bezwzględnego wykonanych metodą C14. Potwierdzają one sugerowaną ahomogenność analizowanego zbioru, jednak dość wyraźnie lokują go w obrębie fazy III, w jej późniejszych odcinkach (b-c), odpowiadającej w skali kalibrowanej przedziałowi 4500/4400 - 3900/3800 BC. Przytoczone rozpoznanie chronometryczne mieści się w przedziale najwcześniejszych oznaczen ${ }^{14} \mathrm{C}$ kujawskiej KPCW, wspierając hipotezę o „zaniku” tych społeczności ok. 1. poł. IV tysiąclecia $\mathrm{BC}^{82}$.

\footnotetext{
${ }^{79}$ Czerniak 1980, tab. 4.

${ }^{80}$ Jażdżewski 1938, tab. XIII - 5 i 5a.

${ }^{81}$ Grygiel 1986, tab. 69-5.

${ }^{82}$ Czerniak 1994, s. 69, 70.
} 


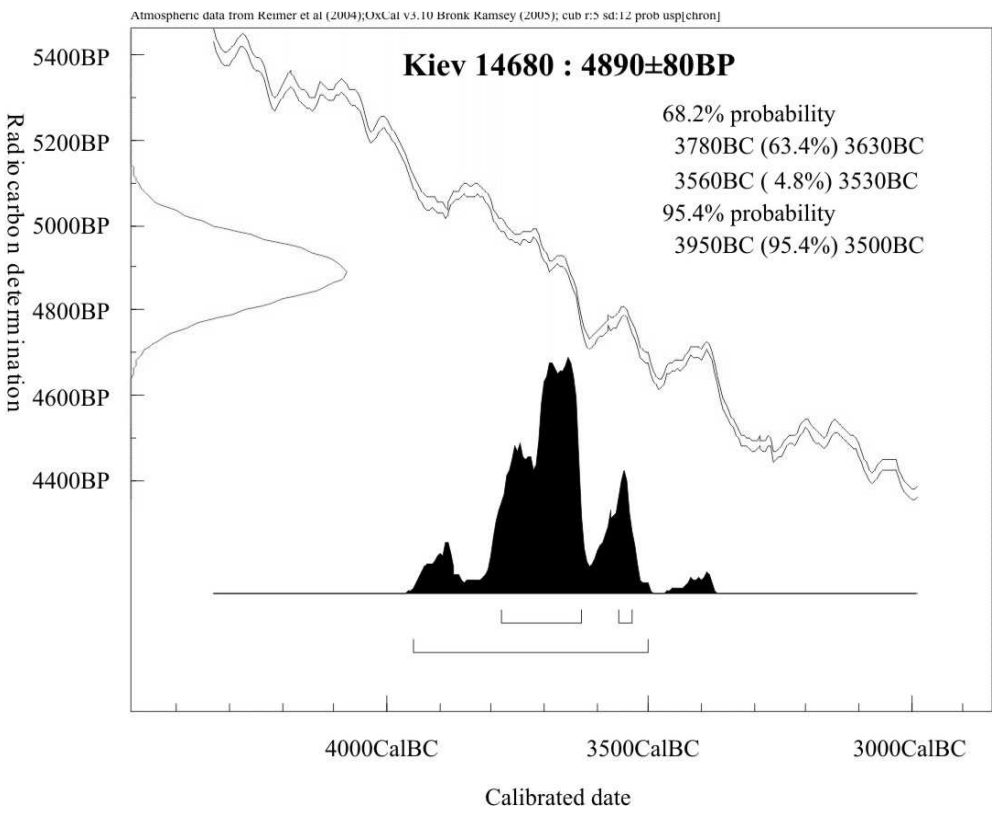

Ryc. 8. Olszewice, stan. 7. Wyniki kalibracji dla obiektu 9

Fig. 8. Olszewice, site 7. Calibration results for feature 9

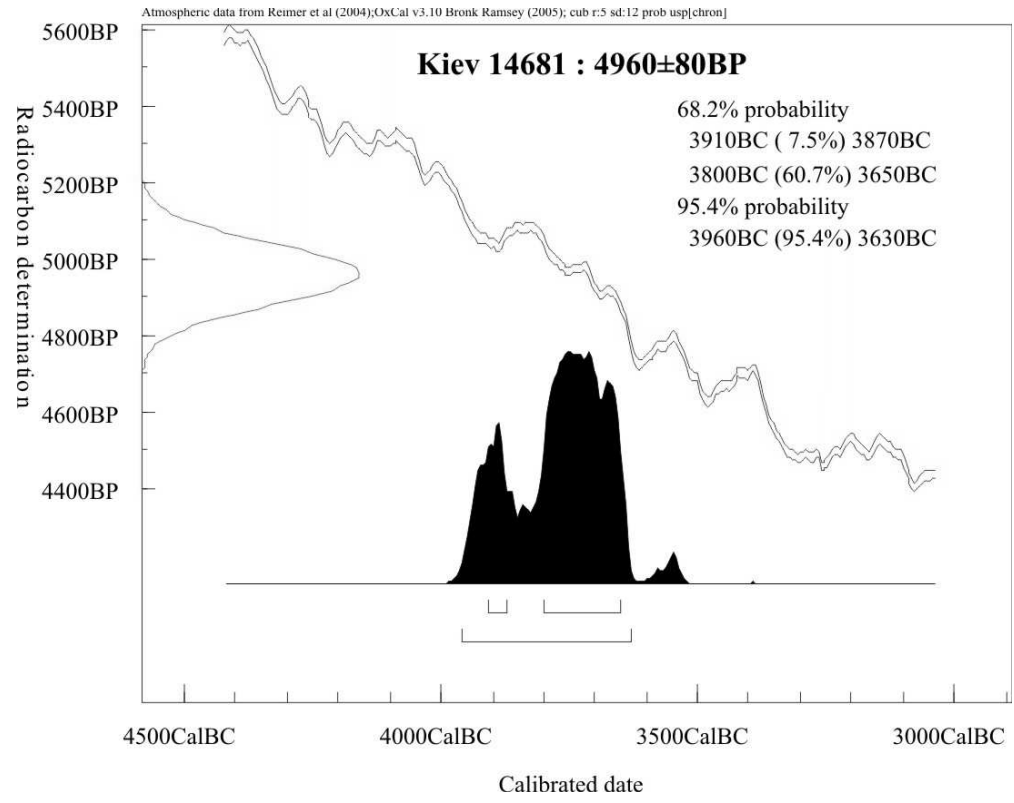

Ryc. 9. Olszewice, stan. 7. Wyniki kalibracji dla obiektu 10

Fig. 9. Olszewice, site 7. Calibration results for feature 10 


\subsection{Wnioski}

Opierając się na przedstawionych wyżej ustaleniach dotyczących chronologii względnej i bezwzględnej, określono następujące przedziały czasowe stanowisk diagnostycznych: Chełmiczki, stan. 10 faza III (ok. 4200-3900/3800 BC), ze szczególnym wskazaniem na fazę IIIbc ( 4000-3900/3800 BC); Karczyn, stan. 21/22 wycinek A faza I (4850-4500 BC)oraz faza Iib-IIIc (4600-3900/3800 BC); Karczyn, stan. 21/22 wycinek B faza IIIb (4000-3900/3800 BC); Olszewice, stan. 7 faza III (4200-3900/3800) ze wskazaniem na podstawie datowania ${ }^{14} \mathrm{C}$ na fazę III $\mathrm{b}-\mathrm{c}$.

\section{4. ŹRÓDŁA OSADNICZE}

Analizowany obszar zdefiniowany w tytule pracy jako wnętrze Wysoczyzny Kujawskiej podlega szczegółowej delimitacji na podstawie sieci arkuszy AZP. Efektem stosowania tego zabiegu, zwłaszcza w północnej części strefy, jest przekroczenie przez jej ramy ewidencyjne przestrzeni tytułowej zlewni ${ }^{83}$. W rozważaniach pominięto stanowiska wyróżnione na kartach AZP tylko i wyłącznie na podstawie znalezisk zabytków kamiennych, określonych jako „toporki kamienne kultur wstęgowych”, gdyż cytowana klasyfikacja może dotyczyć zarówno KPCW, jak i KCWR, ponadto istnieje sugestia, iż omawiana kategoria zabytków stanowiła przedmiot wymiany międzykulturowej ${ }^{84}$ i nie przesądza o wystąpieniu osadnictwa KPCW na takim stanowisku ${ }^{85}$. Ogólnie na całym obszarze badań udokumentowano dotychczas 82 stanowiska „późnowstęgowe”.

$\mathrm{Na} 30$ stanowiskach z omawianej puli prowadzono różnego typu prace wykopaliskowe i sondażowe, co stanowi relatywnie znaczny fragment zbioru (37\%), jednak skala tych działań była w większości przypadków niewielka, często ograniczona do kilku obiektów rejestrowanych na stosunkowo małej przestrzeni. Przeważająca część rozpatrywanych źródeł pochodzi z badań powierzchniowych.

Oznaczenia chronologii względnej, dotyczące podziału na trzy fazy rozwojowe, udało się określić dla 45 stanowisk (54,9\% badanego zbioru). Przy czym w wyniku prac wykopaliskowych datowanie względne określono dla $23 \mathrm{z}$ nich (51\% stanowisk posiadających chronologię). Uściślenia informacji w ramach tej kategorii dokonano, posługując się danymi zawartymi na kartach AZP oraz w dostępnych publikacjach. W trzech przypadkach możliwa była chronologizacja oparta na procedurach datowania technologicznego. Efektem tego zabiegu jest powstanie 5 kategorii klasyfikacyjnych, nieodpowiadających ścisłemu rozgraniczeniu na każdą z faz rozwojowych, ale będących odbiciem rejestracji rzeczywistej sytuacji chronologicznej na danym stanowisku (por. Katalog).

\footnotetext{
${ }^{83}$ Dotyczy to odcinka Kanału Parchańskiego, z jego dopływami, który należy do zlewni rzeki Wisły.

${ }^{84}$ Czerniak 1980, s. 169.

${ }^{85}$ Ilkiewicz 2005, s. 91-115.
} 
Odnośnie do danych pochodzące zarówno z badań powierzchniowych, jak i wykopaliskowych, opracowano klasyfikację funkcjonalną zdefiniowaną na potrzeby projektu $\mathrm{AZP}^{86}$. Weryfikując te informacje, należy uwzględnić ich ocenę krytyczną dotyczącą zwłaszcza ujemnych poznawczo wyników badań powierzchniowych. Odnosi się ona głównie do ułamkowości źródeł powierzchniowych, które podlegając selekcji związanej z procesami naturalnymi i antropogenicznymi, stanowią informacje o nieznanym, potencjalnie bardzo dużym stopniu zubożenia. Wykorzystując wyniki badań powierzchniowych do studiów nad geografią osadnictwa, trzeba również brać pod uwagę odmienne stopnie rozpoznania porównywanych obszarów ${ }^{87}$.

Wśród jednostek klasyfikacyjnych wyróżnione zostały:

a) ślad osadniczy - charakteryzujący się znikomą ilością źródeł ruchomych, bez powiązania $\mathrm{z}$ określoną przestrzenią reliktową;

b) punkt osadniczy rozumiany jako źródło powiązane z określoną przestrzenią (w przypadku dającym możliwość określenia zasięgu stanowiska), w większej liczbie, ale bez możliwości określenia funkcji stanowiska; oraz cmentarzysko/osada i osada jako dwa warianty rejestrowanych funkcji stanowiska ${ }^{88}$.

Tabela 12. „Późnowstęgowe” źródła osadnicze

Table 12. Materials of the Late Band Pottery Culture settlements

\begin{tabular}{|c|c|c|c|c|c|c|c|c|c|c|c|}
\hline \multirow{2}{*}{$\begin{array}{l}\text { Klasyfikacja funk- } \\
\text { cjonalna stanowisk }\end{array}$} & \multirow{2}{*}{$\begin{array}{l}\text { Rodzaj } \\
\text { badań }\end{array}$} & \multicolumn{5}{|c|}{ Fazy chronologiczne } & \multirow{2}{*}{$\begin{array}{l}\text { Stanowiska bez } \\
\text { kwalifikacji } \\
\text { chronologicznej }\end{array}$} & \multicolumn{4}{|c|}{$\Sigma$} \\
\hline & & I & I-II & I-III & II-III & III & & [szt.] & [\%] & [szt.] & [\%] \\
\hline \multirow{2}{*}{ Osada } & $\mathrm{P}$ & 1 & & 3 & & & 3 & 7 & 8,5 & \multirow{2}{*}{24} & \multirow{2}{*}{29,3} \\
\hline & $\mathrm{W}$ & 2 & & 3 & 8 & 2 & 2 & 17 & 20,7 & & \\
\hline \multirow{2}{*}{ Osada/cmentarzysko } & $\mathrm{P}$ & & & & & & 2 & 2 & 2,4 & \multirow{2}{*}{5} & \multirow{2}{*}{6,1} \\
\hline & $\mathrm{W}$ & & & & 2 & & 1 & 3 & 3,7 & & \\
\hline \multirow{2}{*}{ Cmentarzysko } & $\mathrm{P}$ & & & & & & 1 & 1 & 1,2 & \multirow{2}{*}{1} & \multirow{2}{*}{1,2} \\
\hline & $\mathrm{W}$ & & & & & & 0 & 0 & 0,0 & & \\
\hline \multirow{2}{*}{ Punkt osadniczy } & $P$ & & & 1 & 2 & & 5 & 8 & 9,8 & \multirow{2}{*}{10} & \multirow{2}{*}{12,2} \\
\hline & $\mathrm{W}$ & & & 1 & 1 & & & 2 & 2,4 & & \\
\hline \multirow{2}{*}{ Obozowisko } & $\mathrm{P}$ & & & 1 & & & 1 & 2 & 2,4 & \multirow{2}{*}{3} & \multirow{2}{*}{3,7} \\
\hline & $\mathrm{W}$ & 1 & & & & & & 1 & 1,2 & & \\
\hline \multirow{2}{*}{ Ślad osadniczy } & $\mathrm{P}$ & 1 & & 3 & & 1 & 18 & 23 & 28,0 & \multirow{2}{*}{25} & \multirow{2}{*}{30,5} \\
\hline & $\mathrm{W}$ & & & & 2 & & & 2 & 2,4 & & \\
\hline \multirow{2}{*}{$\begin{array}{l}\text { Bez kwalifikacji } \\
\text { funkcjonalnej }\end{array}$} & $P$ & 2 & 2 & & 5 & & & 9 & 11,0 & \multirow{2}{*}{14} & \multirow{2}{*}{17,1} \\
\hline & $\mathrm{W}$ & & & & 1 & & 4 & 5 & 6,1 & & \\
\hline$\Sigma$ & & 7 & 2 & 12 & 21 & 3 & 37 & 82 & 100,0 & 82 & 100,0 \\
\hline
\end{tabular}

$\mathrm{P}$ - badania powierzchniowe; $\mathrm{W}$ - badania wykopaliskowe

${ }^{86}$ Konopka 1984.

${ }^{87}$ Kruk 1981, s. 109-120.

${ }^{88}$ Dla omawianego taksonu charakterystyczne jest występowanie pochówków w obrębie osady i dlatego weryfikacja powierzchniowa stanowiska w kategorii grób/groby łączona jest z współwystępowaniem w tym miejscu osady. 


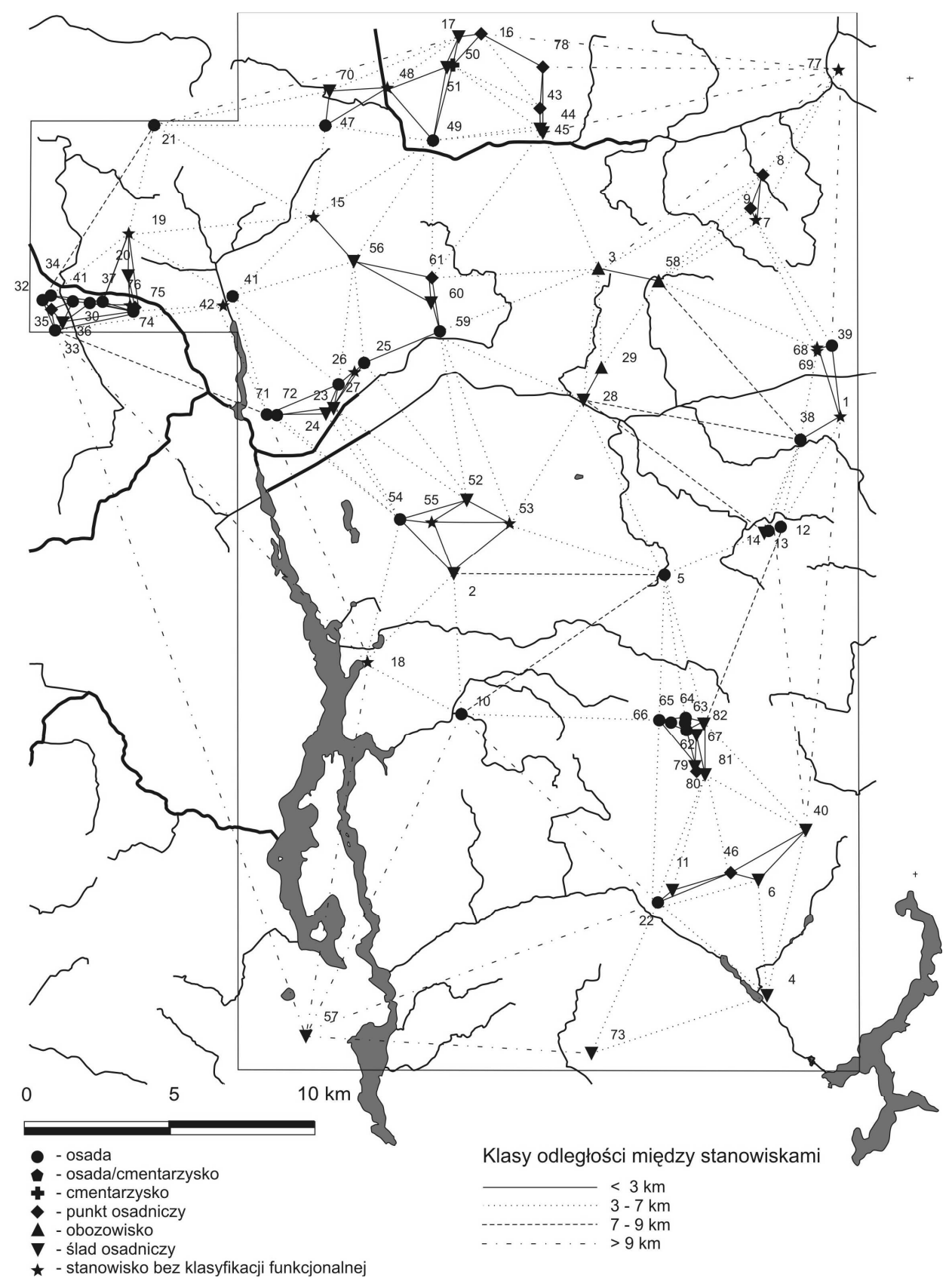

Mapa II. Klasyfikacja funkcjonalna stanowisk ,,późnowstęgowych” z zaznaczonym układem triangulacji dla obszaru badań. Numeracja stanowisk według wykazu

Map II. Functional classification of the Late Band Pottery Culture sites with the marked research area. The site numbers as specified in the list 


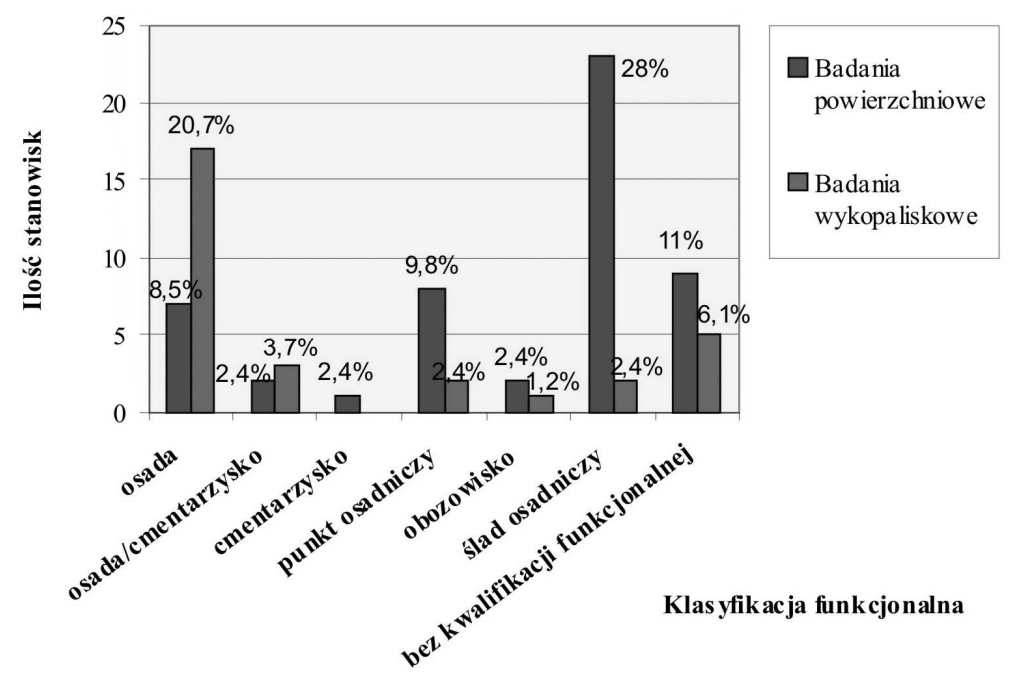

Wykres 1. Klasyfikacja funkcjonalna stanowisk „,późnowstęgowych” Graph 1. Functional classification of the Late Band Pottery Culture sites

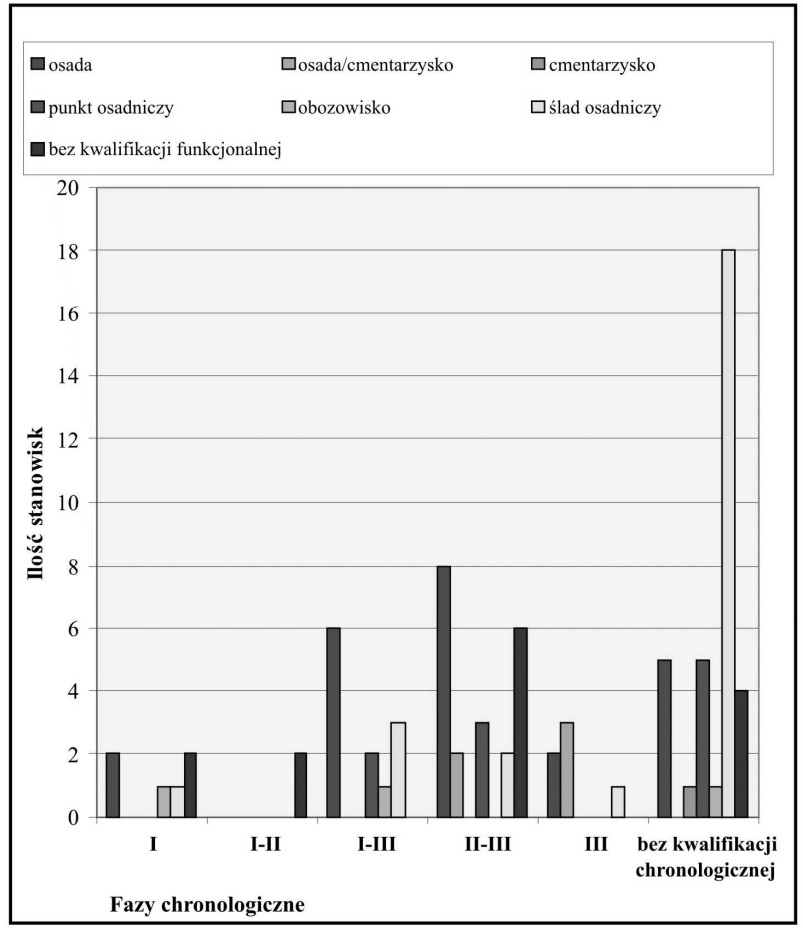

Wykres 2. Klasyfikacja funkcjonalno-chronologiczna stanowisk „późnowstęgowych” Graph 2. Functional and chronological classification of the Late Band Pottery Culture sites 
W efekcie prowadzonej ewidencji klasyfikacje funkcjonalną otrzymało około $83 \%$ badanych stanowisk. Podsumowanie tych zabiegów zawiera tab. 12, wykres 1 i 2 oraz mapa II.

\section{GEOGRAFIA OSADNICTWA}

Geografia osadnictwa stanowi dział geografii definiowany jako: „nauka o zróżnicowaniu przestrzennym struktur społeczno-gospodarczych, rozpatrywanych na tle struktur

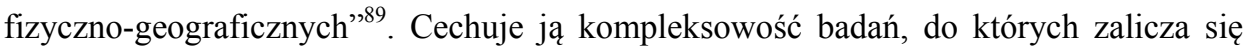
metody: statystyczne, matematyczne, nauk społecznych, ekonomicznych oraz z dziedziny historii. Podręcznikowym sposobem adaptacji metod z dziedziny geografii osadnictwa na potrzeby archeologii jest praca H. Jankuhna ${ }^{90}$. Autor wskazuje możliwość wykorzystania tej nauki do uchwycenia procesów osadniczych, w ścisłym związku z warunkami środowiska naturalnego. Charakteryzuje on źródła do badań archeologiczno-osadniczych oraz wskazuje podstawowe metody badań, ograniczone głównie do sposobów identyfikacji form osadnictwa pradziejowego.

Na gruncie polskiej archeologii osadnictwa wyróżnia się praca J. Kruka ${ }^{91}$. Autor, wychodząc z założenia, iż każdy proces osadniczy generuje powstanie różnych typów osiedli, za cel badań geograficzno-osadniczych przyjmuje opis oraz wyjaśnienie tego, gdzie i dlaczego określone formy osadnictwa występują. Szczególnie cenna jest refleksja nad ułamkowością analizowanych źródeł, które podlegając procesom redukcji pod wpływem czynników naturalnych i antropogenicznych, mogą znacznie utrudniać wnioskowanie. Kolejnym ograniczeniem omawianej metody jest fakt małej możliwości precyzyjnych rozwarstwień chronologicznych materiału, co prowadzi do swojego rodzaju kompakcji źródeł, które w rzeczywistości obejmować mogły szerokie przedziały czasowe.

Operatywna tego ujęcia wydaje się klasyfikacja funkcjonalna rejestrowanych stanowisk (duży stopień przyporządkowania dla całości zbioru), jednak trzeba mieć na uwadze splot takich czynników, jak: warunki pogodowe, częstość podejmowanego rozpoznania danego obszaru, czy stopień zniszczenia badanego stanowiska, które wpływają na ilość rejestrowanego materiału, stanowiąc główne kryterium przy dokonywaniu klasyfikacji funkcjonalnej badanej przestrzeni. Najlepiej obrazuje to dokumentacja osad typu Brześć Kujawski jedynie przez interpretacje charakterystycznych konstrukcji budowlanych na zdjęciach lotniczych, niepotwierdzających się w trakcie badań powierzchniowych. Archeologia przestrzeni, operując nawet tak ograniczonymi danymi, ma szanse uzyskania wartościowych wyników, gdy posługuje się metodami z dziedziny geografii osadnictwa.

\footnotetext{
${ }^{89}$ Kiełczewska-Zaleska 1976

${ }^{90}$ Jankuhn 1983.

${ }^{91}$ Kruk 1980.
} 
Procedura badawcza realizowana przy badaniach geograficzno-osadniczych zawiera się w czterech etapach analitycznych: (1) badaniu ogólnego rozprzestrzeniania śladów osadniczych, (2) ustaleniu przestrzennych relacji między nimi, (3) przeglądzie form osadniczych oraz (4) analizie topografii osadnictwa. Etapy, jak również samo rozumienie pojęcia „geografia osadnictwa”, wraz z akceptacją łączących się z zastosowaniem tej metody ograniczeń, znajduje wyraz w realizacji tej części niniejszej pracy. Wyrazem spełnienia etapu pierwszego jest część katalogowa pracy, zawierająca spis stanowisk „późnowstęgowych” wraz z graficzną prezentacja ich dyspersji. Analiza podstawowych cech sieci osadniczej uzewnętrznia się przez zastosowanie metody triangulacji oraz najbliższego sąsiedztwa w stosunku do analizowanego zbioru elementów. Przegląd form osadnictwa ograniczony został do rozpatrzenia stanowisk diagnostycznych. Etap ostatni realizowany jest przez odniesienie rozpatrywanego zbioru stanowisk do danych uzyskanych z konfrontacji lokalizacji stanowisk w odniesieniu do sieci hydrograficznej i mapy geomorfologicznej.

\subsection{Poziom makroregionalny}

Poziom ten reprezentuje omawiany obszar badań, zdefiniowany jako wschodnia część zlewni jeziora Gopło. Jego bardziej szczegółowa delimitacja zawarta jest we wstępie.

Rozważania w tej części pracy koncentrują się na analizie przestrzennej osadnictwa oraz regułach jego lokalizacji.

\subsubsection{Analiza przestrzenna osadnictwa}

Prezentowane studium zawiera się w następujących etapach: prezentacji założeń metodycznych oraz interpretacji otrzymanych wyników.

\subsubsection{Założenia metodyczne}

Badaniu przestrzeni posłużyły dwie metody: triangulacji Delaunaya oraz metoda najbliższego sąsiada.

- Pełen opis stosowania metody testowania przypadkowości dystrybucji punktów osadniczych, za pomocą dystansów zawiera wspomniana już praca J. Kruka ${ }^{92}$. Stosowanie tej procedury w wersji P. J. Clarka i F. Evansa ${ }^{93}$ polega na łączeniu poszczególnych stanowisk na zasadzie najbliższych sąsiedztw i obliczeń z użyciem pozostałych wartości

\footnotetext{
${ }^{92}$ Kruk 1980, s. $74-77$.

${ }^{93}$ Grochowski, Kostrubiecki, Zagożdżon 1974.
} 
parametru $R$, który jest miarą określającą typ danego układu. W wartościach idealnych, gdy $R=1$ rozkład punktów jest losowy, $R<1$ świadczy, iż mamy do czynienia z układem grupowym. $R>1$ symbolizuje dystrybucję regularną punktów osadniczych.

Ze względu na niski udział stanowisk z oznaczeniami chronologicznymi całość analizowanego układu zdecydowano się potraktować jako jednoczasowy.

- Triangulacja jest zagadnieniem z dziedziny geometrii obliczeniowej. Związana jest $\mathrm{z}$ badaniem skomplikowanych obiektów geometrycznych poprzez rozbicie ich na układy prostsze. Do badania przestrzeni dwuwymiarowej najbardziej pożądane są układy trójkątów o skończonej liczbie elementów, wyznaczających zbiór nie przecinających się przekątnych, które dzielą przestrzeń wielokąta. Przez zastosowanie odpowiednich klas długości, wzorowanych na wcześniej określonych przez J. Pyzel w odniesieniu do osadnictwa KCWR i KPCW, wnioskować można o uchwytnych strukturach w skali mikroi makroregionalnej. Przedziały odległości 0-2 km odpowiadają grupie osad, 2-3 km oraz 3-7 km charakteryzują odległości między sąsiadującymi ze sobą osadami, klasa 7-15 km odpowiada grupom dalej położonym, a odległość ponad 9,5 km przedstawia związki z odmiennymi regionami naturalnymi. Poziom odległości do $3 \mathrm{~km}$ obrazować ma więzi makroregionalne. Stanowiska położone w promieniu do $7 \mathrm{~km}$ odpowiadałyby obszarowi intensywnie zasiedlonemu - regionowi, a powyżej $7 \mathrm{~km}$ interpretowane są jako łączące poszczególne ekumeny.

\subsubsection{Interpretacja otrzymanych wyników}

Analiza otrzymanych rezultatów została przeprowadzona oddzielnie dla każdej z zastosowanych metod. Pierwsza komentuje wyniki uzyskane dla testu R, druga zaś dotyczy metody triangulacji

\subsection{Test $\mathrm{R}$ - interpretacja wyników}

Analiza wykonana za pomocą testu $\mathrm{R}$ potwierdza zgrupowany charakter układu. Otrzymana wartość współczynnika $R(0,734)$ pozwala oprócz określenia typu układu porównać go z innymi tak samo badanymi. Podstawowa trudność w odniesieniu do drugiej możliwości dotyczy braku w strefie niżowej układów zbadanych tego typu metodą. Najbliższe odniesienie stanowi obszar dorzecza Grabi, gdzie wartość parametru $R$ zbadana odnośnie do osadnictwa późnoneolitycznego KPL wynosi w przybliżeniu tyle samo, co jego wartość otrzymana dla badanego układu, co informuje o zbliżonym stopniu koncentracji porównywanych systemów ${ }^{94}$.

Porównaniem jeszcze dalszym jest analiza skupień układu wykonana dla KCWR i kręgu lendzielsko-polgarskiego z obszaru wyżyn lessowych Polski południowo-wschod-

\footnotetext{
${ }^{94}$ Pelisiak 2003.
} 
Tabela 13. Struktura skupisk osadniczych

Table 13. The structure of settlements' clusters

\begin{tabular}{|c|c|c|c|c|c|c|c|c|c|}
\hline \multirow[b]{2}{*}{$\begin{array}{l}\text { Skupi- } \\
\text { ska }\end{array}$} & \multirow[b]{2}{*}{$\begin{array}{l}\text { Numer stanowiska } \\
\text { według katalogu }\end{array}$} & \multirow[b]{2}{*}{$\begin{array}{l}\text { Chronolo- } \\
\text { gia }\end{array}$} & \multicolumn{7}{|c|}{ Klasyfikacja funkcjonalna } \\
\hline & & & Osada & $\begin{array}{c}\text { Osada/ } \\
\text { cmenta- } \\
\text { rzysko }\end{array}$ & $\begin{array}{l}\text { Cmenta- } \\
\text { rzysko }\end{array}$ & Punkt & Ślad & $\begin{array}{l}\text { Obozo- } \\
\text { wisko }\end{array}$ & $\begin{array}{l}\text { Nieokreś- } \\
\text { lone }\end{array}$ \\
\hline \multirow{3}{*}{ I } & $48 \forall$ & II-III & & & & & & & 1 \\
\hline & $47 \forall$ & III & 1 & & & & & & \\
\hline & $\begin{array}{l}16,17,43,44,45,49, \\
50,51,70 \forall, 78\end{array}$ & $?$ & 1 & & 1 & 3 & 5 & & \\
\hline \multirow{2}{*}{ II } & 9 & I-III & & & & 1 & & & \\
\hline & 7,8 & II-III & & & & 1 & & & 1 \\
\hline \multirow{3}{*}{ III } & $25 \forall, 27,72$ & I-III & 3 & & & & & & \\
\hline & $24,59 \forall, 71$ & II-III & 2 & & & & 1 & & \\
\hline & $15 \forall, 23,26,56,60,61$ & $?$ & & & & 1 & 3 & & 2 \\
\hline \multirow{4}{*}{ IV } & 20 & $\mathrm{I}-\mathrm{II}$ & & & & & 1 & & \\
\hline & 75 & I-III & & & & 1 & & & \\
\hline & $\begin{array}{l}19,30 \forall, 31 \forall, 32,33, \\
34,35,36,37\end{array}$ & II-III & 4 & 2 & & 1 & 1 & & 1 \\
\hline & 74,76 & $?$ & & 1 & & & & & 1 \\
\hline \multirow{2}{*}{$\mathrm{V}$} & 42 & $\mathrm{I}-\mathrm{II}$ & & & & & & & 1 \\
\hline & $41 \forall$ & III & 1 & & & & & & \\
\hline \multirow{2}{*}{ VI } & 3 & I-III & & & & & & 1 & \\
\hline & 58 & $?$ & & & & & & 1 & \\
\hline \multirow{3}{*}{ VII } & 1 & I & & & & & & & 1 \\
\hline & 68,69 & II-III & & & & & & & 2 \\
\hline & $38,39 \forall$ & $?$ & 2 & & & & & & \\
\hline \multirow{2}{*}{ VIII } & 29 & $\mathrm{I}$ & & & & & & 1 & \\
\hline & 28 & II-III & & & & & 1 & & \\
\hline \multirow{4}{*}{ IX } & 53 & I-II & & & & & & & 1 \\
\hline & $2,54 \forall$ & II-III & 1 & & & & 1 & & \\
\hline & 52 & III & & & & & 1 & & \\
\hline & 55 & $?$ & & & & & & & 1 \\
\hline \multirow{2}{*}{$\mathrm{X}$} & $12 \forall$ & II-III & 1 & & & & & & \\
\hline & 13,14 & $?$ & 1 & & & & 1 & & \\
\hline \multirow{3}{*}{$\mathrm{XI}$} & 62,65 & I & 2 & & & & & & \\
\hline & 63,64 & II-III & 2 & & & & & & \\
\hline & $66,67,79,80,81,82$ & $?$ & 1 & & & 1 & 4 & & \\
\hline \multirow{3}{*}{ XII } & 6 & I & & & & 1 & & & \\
\hline & 46 & II-III & & & & 1 & & & \\
\hline & $11,22,40$ & $?$ & & 1 & & 1 & 1 & & \\
\hline \multicolumn{2}{|l|}{$\Sigma$} & & 22 & 4 & 1 & 12 & 20 & 3 & 12 \\
\hline
\end{tabular}


cd. tab. 13

\begin{tabular}{|c|c|c|c|c|c|c|c|c|c|}
\hline \multirow[b]{2}{*}{$\begin{array}{l}\text { Skupi- } \\
\text { ska }\end{array}$} & \multirow[b]{2}{*}{$\begin{array}{l}\text { Numer stanowiska według } \\
\text { katalogu }\end{array}$} & \multirow[b]{2}{*}{$\begin{array}{c}\text { Chronolo- } \\
\text { gia }\end{array}$} & \multicolumn{7}{|c|}{ Klasyfikacja funkcjonalna } \\
\hline & & & Osada & \begin{tabular}{|c|} 
Osada/ \\
cmentarzy- \\
sko \\
\end{tabular} & $\begin{array}{l}\text { Cmenta- } \\
\text { rzysko }\end{array}$ & Punkt & Slad & $\begin{array}{c}\text { Obozo- } \\
\text { wisko }\end{array}$ & $\begin{array}{l}\text { Nieokre- } \\
\text { ślone }\end{array}$ \\
\hline \multicolumn{10}{|c|}{ Stanowiska niewystępujące w skupiskach } \\
\hline & 4 & $?$ & & & & & 1 & & \\
\hline & 5 & I & 1 & & & & & & \\
\hline & 10 & II-III & & & & 1 & & & \\
\hline & 18 & II-III & & & & & & & 1 \\
\hline & 21 & $?$ & & 1 & & & & & \\
\hline & 57 & $?$ & & & & & 1 & & \\
\hline & 73 & $?$ & & & & & 1 & & \\
\hline & 77 & $\mathrm{I}$ & & & & & & & 1 \\
\hline \multicolumn{2}{|l|}{$\Sigma$} & & 1 & 1 & & 1 & 3 & & 2 \\
\hline
\end{tabular}

$\forall$ - Stanowiska, na których zlokalizowano tzw. długie domy.

niej ${ }^{95}$. Prosta konfrontacja wartości otrzymanych wskaźników pozwala wnioskować o stopniu skupienia badanego układu, na południu porównywalnym ze stopniem koncentracji osadnictwa cyklu lendzielsko-pologarskiego. Według J. Kruka, rejestrowane na południu grupowe występowanie stanowisk tego cyklu można interpretować jako efekt objęcia procesami zasiedlenia stosunkowo dużego obszaru przez niezbyt liczne społeczności. W opozycji do tego modelu na południu Polski pozostaje regularna lokalizacja punktów osadniczych KPL będąca efektem zasiedlenia terenu przez liczniejsze grupy.

Trudno określić, w jakim stopniu przeprowadzona analiza porównawcza jest uprawomocniona. Biorąc pod uwagę wysoki stopień teoretyczności prowadzonych wyżej spekulacji, należy zastrzec, iż mogą się one nie odnosić do specyficznych warunków naturalnych charakteryzujących obszar Niżu Polski. Rozwinięcie tego zagadnienia wymagałoby przeprowadzenia analiz porównawczych większych obszarów ekumeny ,późnowstęgowej”.

\subsection{Triangulacja - interpretacja wyników}

Zastosowanie metody triangulacji pozwoliło na ujawnienie 12 zgrupowań stanowisk położonych w odległości do $3 \mathrm{~km}$ mających odpowiadać więzi makroregionalnej (mapa II). Wymienione skupienia tworzy 74 z 82 badanych stanowisk. Poza koncentracjami znalazło się jedynie 8 z rozpatrywanych stanowisk. Szczegółową strukturę omawianych zespołów zaprezentowano w tabeli 13.

Skupienie I, wysunięte najdalej na południe w ramach badanego obszaru, tworzy 11 stanowisk. Według klasyfikacji AZP są to 2 osady, stanowisko zaklasyfikowane jako

\footnotetext{
${ }^{95}$ Kruk 1980, s. 79-85.
} 
cmentarzysko, 3 punkty osadnicze, 5 śladów osadniczych oraz stanowisko bez klasyfikacji funkcjonalnej w ramach AZP. Na 3 stanowiskach zlokalizowano długie domy trapezowate (nr 47, 48, 70). Rozpoznaniu wykopaliskowemu poddano tylko jedno $\mathrm{z}$ omawianego kompleksu stanowisk (Olszewice 7, por. stanowiska diagnostyczne). Osada w Parchaniu została wyróżniona na podstawie interpretacji zdjęć lotniczych, gdyż $\mathrm{w}$ trakcie badań powierzchniowych prowadzonych $\mathrm{w}$ obrębie stanowiska nie ujawniono materiału zaklasyfikowanego do ceramiki „późnowstęgowej”. Jedynie $4 \mathrm{z}$ omawianej grupy stanowisk cechują się wyznaczoną chronologią zamykającą się w ramach fazy II-III.

Skupisko II tworzą 3 stanowiska, 1 o nieustalonej klasyfikacji funkcjonalnej oraz 2 punkty osadnicze. Wszystkie punkty klasyfikowane są na podstawie prospekcji powierzchniowej. Datowanie względne omawianego zespołu obejmuje pełną chronologię „późnowstęgową" i zamyka się w obrębie faz I-III.

Skupisko III. To 5 osad, 1 punkt, 4 ślady oraz 2 stanowiska bez odniesienia do klasyfikacji funkcjonalnej. Na 3 stanowiskach w tym rejonie zarejestrowano „późnowstęgowe" konstrukcje domostw. W przypadku stanowiska w miejscowości Dziennice założenie o istnieniu pozostałości konstrukcji mieszkalnej nie jest jednoznaczna, z uwagi na bardzo złożoną stratygrafię tego stanowiska oraz stosunkowo niewielki zbiór zabytków ruchomych. $\mathrm{Z}$ zespołu 12 stanowisk wykopaliskowo zbadano 7 dla $6 \mathrm{z}$ nich ustalono chronologię względną zamykającą się w obrębie faz I -III.

Skupisko IV to znany z wcześniejszych opracowań mikroregion „kruszański”. W rozpatrywanej tam przestrzeni zaliczyć można do niego 7 osad (w tym 2 stanowiska z rozpoznaną zabudową długich domów), 2 punkty osadnicze, 2 ślady osadnicze oraz 2 stanowiska o nieustalonej klasyfikacji. Dziewięć z 13 stanowisk poddano weryfikacji wykopaliskowej.

Skupisko V to 2 stanowiska zlokalizowane w miejscowości Łojewo. Rozłączne chronologicznie - osada z długim domem, rozpoznana wykopaliskowo, datowana jest na fazę III oraz punkt osadniczy z fazy I-II.

Skupisko VI tworzą 2 stanowiska opisane jako obozowiska. Zweryfikowane na drodze rozpoznania powierzchniowego.

Skupisko VII stanowią 2 osady (na jednej odnotowano długie domy Kuczkowo 5) oraz 3 punkty o nieustalonej funkcji. Stanowiska rejestrowane są przy wschodniej granicy obszaru badań i przestrzennie związane są zapewne z zespołami osadniczymi zlokalizowanymi w dorzeczu Bachorzy, ciągnącymi się w kierunku wschodnim aż do rejonu Brześcia Kujawskiego i Osłonek.

Skupisko VIII są to 2 stanowiska - obozowisko i ślad osadniczy badane wykopaliskowo, funkcjonujące w odmiennych przedziałach chronologicznych (fazy I oraz II-III).

Skupisko IX składa się z 5 stanowisk 1 osady, 2 śladów osadniczych oraz 2 nie zaklasyfikowanych stanowisk. Trzy punkty badane były wykopaliskowo. Na osadzie zidentyfikowano pozostałości 3 długich domów będących fragmentem większego osiedla.

Wśród 3 stanowisk składających się na skupisko X zarejestrowano 2 osady oraz ślad osadniczy. Na jednej z osad w wyniku prac wykopaliskowych odnotowano zabudowę w typie Brześcia Kujawskiego. 
Skupisko XI to znaczna koncentracja pozostałości osadnictwa „późnowstęgowego”. Odnotowano tutaj 6 osad 1 punkt oraz 4 ślady osadnicze. Cztery stanowiska rozpoznane były wykopaliskowo, jednak badania nie ujawniły charakterystycznego dla omawianej jednostki kulturowej typu zabudowy.

Skupisko XII grupuje stanowiska najbardziej wysunięte na południe w zlewni jeziora Gopło w odniesieniu do całej ekumeny ,późnowstęgowej”. Poza tą koncentracją pozostają jeszcze 3 oddalone od siebie stanowiska, będące rubieżą omawianej ekumeny w odniesieniu do jej południowego zasięgu. W strukturze osadniczej przeważają ślady i punkty osadnicze, w kategorii osady mieści się tylko 1 stanowisko. Żaden z omawianych w tym skupieniu punktów nie był weryfikowany wykopaliskowo.

Stanowiska niebudujące opisanych wyżej skupień mogły zostać odseparowane od właściwych dla nich koncentracji przez wykreślenie obszaru badań (tak jest zapewne w przypadku stanowiska w miejscowości Wilkostowo w północno-wschodnim zasięgu obszaru badań) lub też w przypadku rejestracji takich stanowisk wewnątrz badanego obszaru mogą świadczyć o odmiennych formach eksploatacji danej przestrzeni. Całość powyższej w tym miejscu interpretacji należy jednak traktować wyłącznie w kategoriach supozycji, gdyż przestrzeń ta cechuje się nierównomiernym stopniem rozpoznania z zastosowaniem inwazyjnych i nieinwazyjnych metod badawczych.

\subsubsection{Reguły lokalizacji form osadnictwa w odniesieniu do wybranych składników środowiska}

Obecny obraz środowiska naturalnego Wysoczyzny Kujawskiej przedstawia się jako wizerunek silnie przekształcony pod wpływem oddziaływań antropogenicznych. Już od IV tysiąclecia p.n.e. teren ten poddany był intensywnym zabiegom gospodarczym związanym z rejestrowanym tu osadnictwem. W okresach późniejszych, poczynając od XVIII w., stopień ingerencji człowieka w otaczającą go przestrzeń manifestował się na niezwykle dużą skalę i doprowadził do diametralnych przemian środowiska. Procesy odlesień, intensywne zabiegi agrotechniczne i melioracyjne na zawszę zmieniły tę krainę.

Reguły lokalizacji form osadnictwa rozpatrzone zostały tutaj przez analizę zbioru stanowisk w aspektach związanych z ich lokalizacją względem: głównej hydrografii obszaru oraz podstawowych jednostek geomorfologicznych.

\subsubsection{Rozmieszczenie względem głównej hydrografii obszaru}

Większość badanego terenu obejmuje zlewnię jeziora Gopło oprócz wycinków w południowej i północno-wschodniej części rejonu badań. Tak jest w przypadku skupiska I zlokalizowanego nad Kanałem Parchańskim i jego dopływami. Większość omówionych wcześniej koncentracji osadniczych, które mogą być interpretowane jako mikroregiony osadnicze, związana jest z głównymi ciekami tego obszaru (osadnictwo oko- 


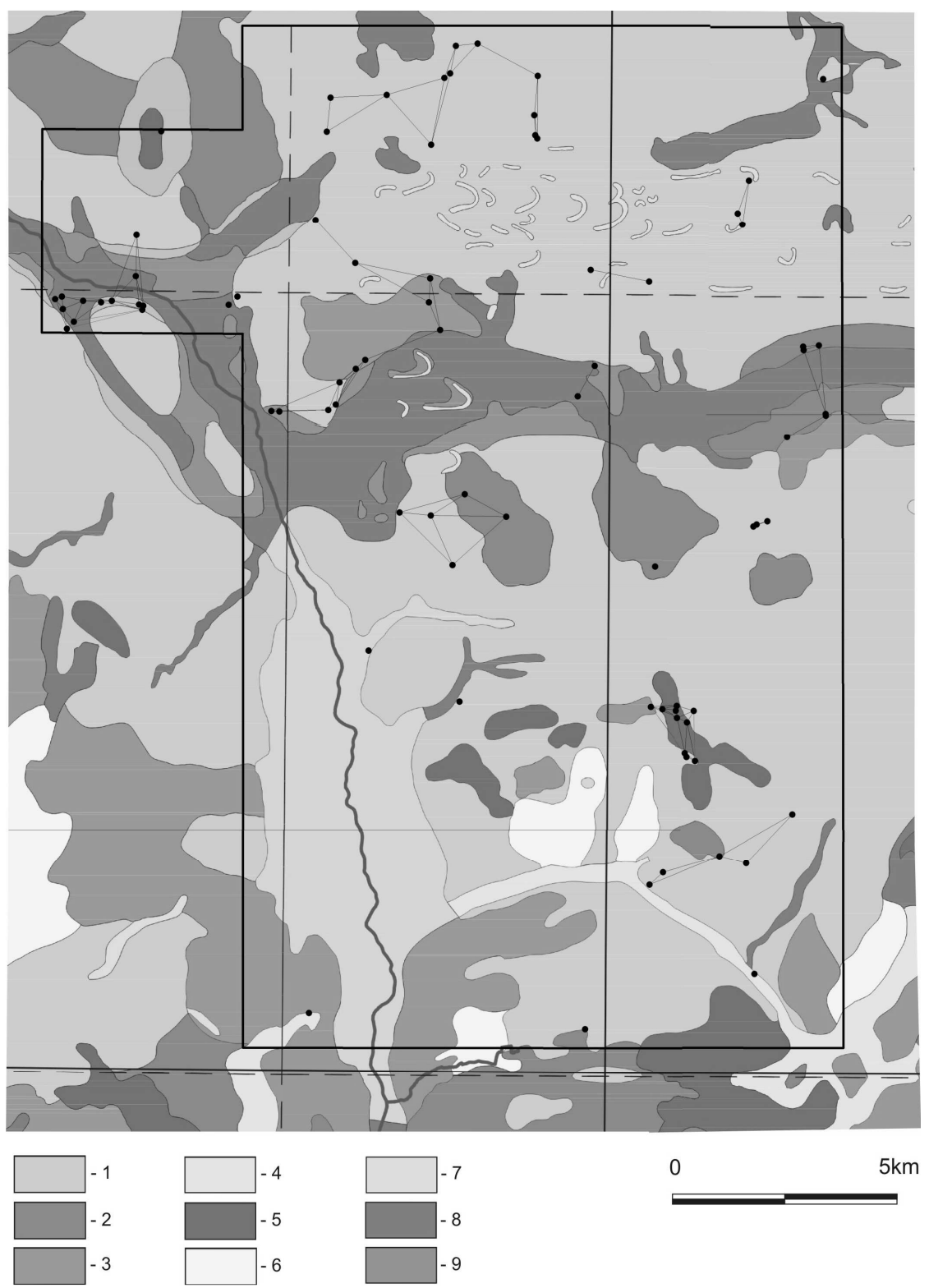

Mapa III. Wycinek mapy geomorfologicznej z zaznaczonym obszarem badań oraz skupiskami stanowisk, których w układzie triangulacji odległość nie przekracza $3 \mathrm{~km}$. 1 - wysoczyzna morenowa płaska; 2 - wysoczyzna morenowa falista; 3 - wysoczyzna morenowa pagórkowata; 4 - rynna o dnie płaskim; 5 - strefa pagórków morenowych; 6 - równiny sandrowe; 7 - pagórki wydmowe; 8 - terasa zalewowa denna; 9 - terasa środkowa, wydmowa

Map III. The geomorphological map of the research area with marked concentrations of sites within $3 \mathrm{~km}$ realm. 1 - flat morainic plateau, 2 - undulated morainic plateau, 3 - hilly morainic plateau, 4 - tunnel valley with a flat bottom, 5 - zone of moraine hills, 6 - outwash plain, 7 - dune hills, 8 - bottom floodplain terrace, 9 - middle terrace with dunes 
lic Kruszy Zamkowej związane z Notecią, osadnictwo okolic Radojewic i Karczyna o przebiegu liniowym związanym z przebiegiem kanału Bachorze Małe, stanowisko w Chemiczkach zlokalizowane nad mniejszym ciekiem). Występują też koncentracje osadnictwa niezwiązane w sposób tak oczywisty z dzisiejszymi wodami płynącymi czy stojącymi. Są to skupiska z okolic Piecek i Radziejowa.

\subsubsection{Rozmieszczenie względem podstawowych jednostek geomorfologicznych}

W odniesieniu do południowej części obszaru badań ujawnia się tendencja do lokalizacji osadnictwa wzdłuż teras zalewowych Noteci i Bachorzy, w strefie jej pogranicza z moreną płaską (mapa III). Czytelna jest też wyraźna anekumena osadnicza w miejscu występowania pagórków wydmowych, w obrębie wysoczyzny morenowej płaskiej. Osadnictwo ,późnowstęgowe” na południe od doliny Bachorzy występuje na przeważającej w tej części obszaru wysoczyźnie morenowej płaskiej, w pewnej mierze wiążąc się z występującym miejscowo urozmaiceniem krajobrazu w postaci pagórków morenowych.

\subsection{Poziom mikroregionalny: osada i jej kontekst}

Rozważania prowadzone na tym poziomie analizy opierają się na informacjach uzyskanych w wyniku opracowania stanowisk diagnostycznych. Refleksja dotyczyć będzie dwóch aspektów: osady oraz jej powiązań przestrzennych. Zagadnienie topogenezy omawianych społeczność przedstawione będzie w punkcie 2.1.2.

\subsubsection{Osady}

- Na podstawie ogólnej analizie źródeł pozyskanych ze stanowiska Chemiczki 10 można zaklasyfikować je do kategorii osad. Z pewnością wąski pas eksploracji tego obszaru, jak też znaczne zakłócenie układu przez osadnictwo późniejsze, przyczyniło się do absencji trwałych konstrukcji mieszkalnych związanych z omawianym taksonem. Materiał źródłowy grupuje się jednak dość wyraźnie w obrębie dwóch sygnalizowanych już skupisk, oddalonych od siebie o około 40-45 m w układzie północ-południe. Skupiska te, w przybliżeniu jednoczasowe ${ }^{96}$, odpowiadać mogą dwóm odrębnym układom domom z zapleczem gospodarczym - podwórzem.

Analiza struktury gleb wykonana w promieniu $1 \mathrm{~km}$ od stanowiska Chemiczki 10 wpisuje tę osadę w główny nurt ,późnowstegowych” preferencji rodzajów gleb. Przejawia się to wysokim udziałem czarnych ziem $(81,81 \%)$, z niewielką domieszką utworów bielicowych $(4,29 \%)$ oraz bagiennych $(13,89 \%)$.

\footnotetext{
${ }^{96}$ Zbieżna chronologia ustalona została na podstawie cech technologicznych ceramiki.
} 
- Osadnictwo z Karczyna, datowane na I fazę KPCW, nie jest łączone z żadnym obiektem nieruchomym i dlatego rozważania o sposobie funkcjonowania tego osadnictwa nie są możliwe. Osadnictwo z poziomu fazy III dotyczy funkcjonowania w tej przestrzeni domu z podwórzem, przy czym trudno wnioskować, czy omawiane założenie jest formą odosobnioną, czy też stanowi część większej osady. Za rozwiązaniem pierwszym, mówiącym o wystąpieniu pojedynczej formy mieszkalnej, przemawiałby fakt, iż znaczna część wzgórza oraz jego stok wschodni zostały objęte badaniami wykopaliskowymi, które nie ujawniły żadnej podobnej formy (por. ryc. 2). Z kolei na możliwość wystąpienia większej liczby chat trapezowatych wskazuje lokalizacja, na kulminacji wzgórz (wycinek A, ryc. 2), współczesnego wybierzyska gliny, które mogło unicestwić istniejące tam ślady osadnicze.

Analizując osadnictwo tej fazy zasiedlenia stanowiska, można zasugerować związek funkcjonalny chaty i towarzyszących jej obiektów gospodarczych z wycinka A, z oddalonymi od nich w linii prostej o około 25 i 55 m na północny zachód jamami określonymi jako glinianki (wycinek B, obiekty 232, 240 i 97).

Za pomocą analizy struktury gleb przeprowadzona dla stanowiska w Karczynie ujawniono wysoki udział gleb bagiennych $(41,42 \%)$, dość wysoki udział czarnych ziem $(35,46 \%)$ oraz niewielki komponent bielic $(1,74 \%)$.

Układ zarejestrowany w Olszewicach wskazuje na istnienie dwóch odrębnie funkcjonujących gospodarstw, na które składała się chata trapezowata oraz obiekty gospodarcze. Zespół pierwszy tworzy chata trapezowata oraz obiekty 9 i 10, ulokowane po zachodniej części domu, blisko jej krańca południowego, interpretowane jako glinianki przekształcone następnie w jamy śmietniskowe. Drugi zespół obiektów oddalony od omówionego o około $10 \mathrm{~m}$ w kierunku zachodnim tworzy chata trapezowata $\mathrm{z}$ jamą wewnętrzną, która mogła pełnić funkcję piwnicy oraz ulokowana również po zachodniej części domu glinianka - jama odpadkowa.

Na podstawie analizy szczątków kostnych z obiektu 9 (glinianki - jamy śmietnikowej) wykazano na dwóch fragmentach kości udowej bydła ślady charakterystycznego poprzecznego rąbania w celu dotarcia do szpiku. Postępowanie takie, a także kontekst lokalizacja tych szczątków mogą być interpretowane jako przejaw pewnych zachowań społecznych. Zachowania te polegałyby na rytualnej konsumpcji smażonego szpiku bydlęcego, która „miała odbywać się pomiędzy długimi domami, a jej pozostałości w postaci szczątków kostnych były deponowane w jamach określanych mianem glinianek" "97. Czynność ta była powtarzana w sposób cykliczny i charakteryzowała w większym stopniu KCWR. W odniesieniu do KPCW miała być to praktyka, której znaczenie zmalało. Za pomocą analizy struktur gleb przeprowadzona w promieni $1 \mathrm{~km}$ od osady wykazano znaczącą przewagę czarnych ziem (98,38\%), z nieznacznym udziałem gleb bielicowych $(1,74 \%)$.

\footnotetext{
${ }^{97}$ Marciniak 2004, s. 38.
} 


\subsubsection{Powiązania przestrzenne}

- W ramach analizowanych układów przestrzennych, w oparciu o otrzymane wyniki (por. mapy I-III), stanowisko w Chełmiczkach, datowane na fazę III wykazuje związki z podobnie datowanymi w Gocanowie, Altanie oraz stanowiskami w Pieckach. Cechą łączącą wymienioną grupę stanowisk jest wspólny dla nich przedział odległości 3 do $7 \mathrm{~km}$ oraz zbieżna chronologia. Interpretacja tego zespołu jako mikroregionu jest utrudniona $\mathrm{z}$ racji na niezaznaczające się, w ramach omawianych przedziałów odległości, przerwy względem kolejnego skupienia stanowisk w okolicach Karczyna.

- Jednoznaczna interpretacja powiązań przestrzennych osady w Karczynie jest trudna. Niewątpliwie należy ona do grupy osad sobie najbliższych, tworzących skupisko III.

- Inspirującą przesłanką do rozpatrzenia powiązań wewnątrzkulturowych, w ramach omawianego taksonu na stanowisku w Olszewicach, jest fragment specyficznie zdobionego naczynia. Najbliższymi odpowiednikami wykorzystania tej samej strefy naczynia do umieszczenia tam zdobienia są okolice Brześcia Kujawskiego (stan. 4 i 3).

\subsection{Topogeneza}

Powiązania kulturowe społeczności późnowstęgowych, w ramach badanego zbioru ceramiki ze stanowisk diagnostycznych, przedstawione mogą być $\mathrm{w}$ dwóch etapach dotyczących fazy I oraz fazy III KPCW.

Poziom fazy I jest powiązany z ceramiką ze stanowiska Karczyn 21/22, rejestrowany w ramach wycinka A. Odnotować możemy tu układ więzi o charakterze południkowym „śląsko-czeskim”, przejawiający się wystąpieniem wątków „kłutych”. Rejestracja zdobień w stylu „,rösseńskim” wplata to stanowisko w powiązania topogenetyczne o charakterze równoleżnikowym. Stanowisko to położone nad współczesnym kanałem Bachorze Małe, należy do ciąg komunikacyjnego pomiędzy Odrą a Wisłą ${ }^{98}$.

Odnośnie do powiązań międzykulturowych społeczności KPCW z fazy III, o przebiegu południkowym, wnioskować można na podstawie fragmentarycznie zachowanego naczynia ze stanowiska Olszewice 7, którego cechy technologiczne wskazują na powiązanie go ze strefą kultury lubelsko-wołyńskiej w sensie bezpośredniego przeniesienia „importu” omawianej ceramiki ${ }^{99}$.

\section{ZAKOŃCZENIE}

Przedmiotowe źródła analizowane były w dwóch wzajemnie powiązanych nurtach. Pierwszy z nich dotyczył poziomu analizy mikroregionalnej ograniczonej do stanowisk

\footnotetext{
${ }^{98}$ Czerniak 2008, s. 74.

${ }^{99}$ Informacja ustna uzyskana od prof. dr. hab. L. Czerniaka w trakcie konsultacji całości omawianego $\mathrm{w}$ tej pracy materiału ceramicznego.
} 
diagnostycznych (Chełmiczki 10, Karczyn 21/22 oraz Olszewice 7). Wieloaspektowa charakterystyka źródeł ruchomych i nieruchomych, pochodzących z wymienionych stanowisk, dała podstawę do podjęcia problematyki funkcji, chronologii i topogenezy, przypisując je do kategorii osad, w przypadku Karczyna datowanych na fazę I i III, a pozostałych na fazę III. Drugi stopień analizy koncentruje się na rozważaniach związanych z geografią osadnictwa. W nawiązaniu do układu makroregionalnego osadza ogół stanowisk diagnozowanych w skali ich powiązań przestrzennych i kulturowych.

Koligacje przestrzenne rozpatrywane są również dla poziomu makroregionu ograniczonego do obszaru zdefiniowanego w tytule pracy. Zastosowane metody ujawniły znaczny stopień koncentracji osadnictwa „późnowstęgowego” w badanej przestrzeni, jednak jego interpretacja $\mathrm{w}$ układach makroregionalnych jest znacznie utrudniona $\mathrm{z}$ uwagi na problemy związane $\mathrm{z}$ ich wyodrębnieniem na podstawie wykorzystanych miar odległości oraz niewielkiej liczby oznaczeń chronologicznych dostępnych dla tych stanowisk.

Zaznaczyć należy w tym miejscu jeszcze jeden aspekt aplikacji metod z dziedziny geografii osadnictwa na grunt archeologii. Mieści się on w orientacji metodologicznej rozwijającej, w ramach archeologii, podejście scjentystyczne do geografii osadnictwa. Wykorzystuje ono w szerokim spektrum mapę, wykresy, tabelę, prawidłowości statystyczne oraz modele matematyczne przyczyniając się do znaczne lepszego poznania zróżnicowań organizacji przestrzennej badanych zjawisk, jednak nie uwzględnia pewnych istotnych zmiennych płynących z natury człowieka. Podejście behawioralne, czy wręcz humanistyczne w odniesieniu do geografii osadnictwa umozliwia zadanie pytania o złożoność ludzkiej motywacji, pozwalając dostrzec w czysto fizycznych atrybutach przestrzeni również jej cechy społeczne.

Wykaz stanowisk ,późnowstęgowych”

List of the Late Band Pottery Culture sites

\begin{tabular}{|r|l|c|l|l|l|c|c|}
\hline Lp. & Stanowisko & $\begin{array}{c}\text { Klasyfikacja } \\
\text { chronolo- } \\
\text { giczna }\end{array}$ & $\begin{array}{c}\text { Klasyfikacja } \\
\text { funkcjonalna }\end{array}$ & Lp. & Stanowisko & $\begin{array}{c}\text { Klasyfikacja } \\
\text { chronolo- } \\
\text { giczna }\end{array}$ & $\begin{array}{c}\text { Klasyfikacja } \\
\text { funkcjonalna }\end{array}$ \\
\hline 1 & Altana 3 & I & - & 45 & Modliborzyce 49 & - & ślad osadniczy \\
2 & Bachorce 4 & II-III & ślad osadniczy & 46 & Nasiłowo 8 & II-III & punkt osadniczy \\
3 & Bąkowo 3/3A & I-III & obozowisko & 47 & Olszewice 7 & III & osada \\
4 & Borowo 2 & - & ślad osadniczy & 48 & Parchanie 30 & II-III & - \\
5 & Broniewo-Kolonia 1 & I & osada & 49 & Parchanie 72 & - & osada \\
6 & Bytoń 8 & I & ślad osadniczy & 50 & Parchanki 27 & - & cmentarzysko \\
7 & Chlewiska 1 & II-III & - & 51 & Parchanki 29 & - & ślad osadniczy \\
8 & Chlewiska 38 & II-III & punkt osadniczy & 52 & Piaski 2 & III & ślad osadniczy \\
9 & Chlewiska 114 & I-III & punkt osadniczy & 53 & Piaski 4 & I-II & - \\
10 & Chełmiczki 10 & II-III & punkt osadniczy & 54 & Piecki 1 & II-III & osada \\
11 & Czarnotka 1 & - & ślad osadniczy & 55 & Piecki 11 & - & - \\
12 & Dobre 6 & II-III & osada & 56 & Pławinek 32 & - & ślad osadniczy \\
13 & Dobre 38 & - & osada & 57 & Połajewo Stare 15 & - & ślad osadniczy \\
\hline
\end{tabular}


cd. Wykazu

\begin{tabular}{|c|c|c|c|c|c|c|c|}
\hline Lp. & Stanowisko & $\begin{array}{l}\text { Klasyfikacja } \\
\text { chronolo- } \\
\text { giczna }\end{array}$ & $\begin{array}{l}\text { Klasyfikacja } \\
\text { funkcjonalna }\end{array}$ & Lp. & Stanowisko & $\begin{array}{l}\text { Klasyfikacja } \\
\text { chronolo- } \\
\text { giczna }\end{array}$ & $\begin{array}{l}\text { Klasyfikacja } \\
\text { funkcjonalna }\end{array}$ \\
\hline 14 & Dobre 39 & - & ślad osadniczy & 58 & Przybysław 62 & - & obozowisko \\
\hline 15 & Dziennice 2 & - & - & 59 & Radojewice 29 & II-III & osada \\
\hline 16 & Gąski 7 & - & punkt osadniczy & 60 & Radojewice 64 & - & ślad osadniczy \\
\hline 17 & Gąski 15 & - & ślad osadniczy & 61 & Radojewice 1 & - & punkt osadniczy \\
\hline 18 & Gocanowo 40 & II-III & - & 62 & Radziejów 5 & I & osada \\
\hline 19 & Inowrocław 95 & II-III & - & 63 & Radziejów 6 & II-III & osada \\
\hline 20 & Inowrocław Mątwy 1 & I-II & ślad osadniczy & 64 & Radziejów 7 & II-III & osada \\
\hline 21 & Inowrocław Mątwy 20 & - & $\begin{array}{l}\text { osada/cmenta- } \\
\text { rzysko }\end{array}$ & 65 & Radziejów 12 & I & osada \\
\hline 22 & Kaczewo 15 & - & $\begin{array}{l}\text { osada/cmenta- } \\
\text { rzysko }\end{array}$ & 66 & Radziejów 13 & - & osada \\
\hline 23 & Karczyn 11 & - & ślad osadniczy & 67 & Radziejów 52 & - & ślad osadniczy \\
\hline 24 & Karczyn 13 & II-III & ślad osadniczy & 68 & Sędzin Pierwszy 11 & II-III & - \\
\hline 25 & Karczyn 21/22 & I-III & osada & 69 & Sędzin Pierwszy 12 & II-III & - \\
\hline 26 & Karczyn 23/24 & - & - & 70 & Słońsko 54 & - & ślad osadniczy \\
\hline 27 & Karczyn 32 & I-III & osada & 71 & Szarlej 6 & II-III & osada \\
\hline 28 & Konary 6 & II-III & ślad osadniczy & 72 & Szarlej 6a & I-III & osada \\
\hline 29 & Konary 20 & I & obozowisko & 73 & Szewce 6 & - & ślad osadniczy \\
\hline 30 & Krusza Zamkowa 2A & II-III & osada/cmentarzysko & 74 & Tupadły 16 & - & $\begin{array}{l}\text { osada/cmenta- } \\
\text { rzysko }\end{array}$ \\
\hline 31 & Krusza Zamkowa 3 & II-III & osada/cmentarzysko & 75 & Tupadły 22 & I-III & punkt osadniczy \\
\hline 32 & Krusza Zamkowa 7 & II-III & osada & 76 & Tupadły 23 & - & - \\
\hline 33 & Krusza Zamkowa 8 & II-III & osada & 77 & $\begin{array}{l}\text { Wilkostowo } \\
23 / 24\end{array}$ & I & - \\
\hline 34 & Krusza Zamkowa 9 & II-III & osada & 78 & Wonorze 19 & - & punkt osadniczy \\
\hline 35 & Krusza Zamkowa 13 & II-III & punkt osadniczy & 79 & Zagórzyce 15 & - & ślad osadniczy \\
\hline 36 & Krusza Zamkowa 15 & II-III & ślad osadniczy & 80 & Zagórzyce 18 & - & punkt osadniczy \\
\hline 37 & Krusza Zamkowa 30 & II-III & osada & 81 & Zagórzyce 21 & - & ślad osadniczy \\
\hline 38 & Krzywosądź 3 & - & osada & 82 & Zagórzyce 22 & - & ślad osadniczy \\
\hline 39 & Kuczkowo 5 & - & osada & & & & \\
\hline 40 & Litychowo 8 & - & ślad osadniczy & & & & \\
\hline 41 & Lojewo $1 / 2$ & III & osada & & & & \\
\hline 42 & Łojewo 4 & I-II & - & & & & \\
\hline 43 & Modliborzyce 60 & - & punkt osadniczy & & & & \\
\hline 44 & Modliborzyce 47 & - & ślad osadniczy & & & & \\
\hline
\end{tabular}

\section{BIBLIOGRAFIA}

Bednarczyk J., Czerniak L., Kośko A.

1980 Z badań nad zespołem osadniczym ludności kręgu kultury ceramiki wstęgowej w Kruszy Zamkowej, stan. 3 woj. Bydgoszcz (część sepulkralna), „Sprawozdania Archeologiczne”, t. XXXII, s. 55-83. 
Bednarczyk J., Kośko A., Krause E.

1979 Z problematyki rozwoju kultury lendzielskiej w rynnie Jeziora Pakoskiego (ze studiów nad rozwojem kultur wstęgowych na Kujawach), „Pomorania Antiqua”, t. 8, s. 9-41.

Bogucki P.

1979 Tactical and strategic settlements In the Elary Neolithic of Lowland Poland, „Journal of Anthropological Research", vol. 35, z. 2, s. 238-246.

Chachlikowski P.

1996 Ze studiów nad pochodzeniem i użytkowaniem surowców importowanych w wytwórczości kamieniarskiej społeczności wczesnorolniczych Kujaw, (w:) Z badań nad genezą regionalizmu społeczeństw Kujaw. Studia i materiały do dziejów Kujaw - Niżu Polski, red. A. Kośko, vol. 6, Poznań, s. 121-153.

Czarnecka H. (red.)

2005 Atlas. Podziały hydrograficzne Polski. Część 1. Mapy w skali 1: 200 000, Warszawa.

Czebreszuk J., Kośko A., Szmyt M.

2006 Zasady analizy źródeł ceramicznych z okresu późnego neolitu oraz interstadium epoki neolitu $i$ brązu na Kujawach, (w:) Opatowice - Wzgórze Prokopiaka, t. I: Studia i materiały do badań nad późnym neolitem Wysoczyzny Kujawskiej, red. A. Kośko, M. Szmyt, Poznań, s. 39-64.

Czerniak L.

1978 Konary, woj. Bydgoszcz, stan. 20. Obozowisko ludności kultury lendzielskiej (Ze studiów nad rozwojem kultur wstęgowych na Kujawach), „Sprawozdania Archeologiczne”, t. XXX, s. 33-55.

1979a Osada kultury lendzielskiej w Kościelcu Kujawskim, gm. Pakość, stan. 16 (Ze studiów nad rozwojem kultur wstęgowych na Kujawach), „Pomorania Antiqua”, t. 8, s. 73-109.

1979b Z badań nad problematyka równoleżnikowych kontaktów kulturowych społeczeństw dorzecza Odry $i$ Wisły w młodszej epoce kamienia (Zagadnienie tzw. wpływów kultury rösseńskiej), „Wiadomości Archeologiczne", t. XLIV, s. 123-129.

1980 Rozwój społeczeństw kultury późnej ceramiki wstęgowej na Kujawach, Poznań.

1992 Weggierce, gm. Pakość, stan. 12. Osiedle z fazy Ia kultury późnej ceramiki wstęgowej na Kujawach, „Sprawozdania Archeologiczne”, t. XLIV, s. 31-47.

1994 Wczesny i środkowy okres neolitu na Kujawach 5400-3650 p.n.e., Poznań.

1996a Kultura malicka a postlinearne kultury Niżu Polski, (w:) Kultura malicka (Drugi etap adaptacji naddunajskich wzorców kulturowych w neolicie północnej części środkowej Europy), red. J. K. Kozłowski, Kraków, s. 71-77.

1996b Kultura późnej ceramiki wstęgowej versus grupa brzesko-kujawska ( $W$ związku $z$ referatem R. Grygla), (w:) Kultura malicka (Drugi etap adaptacji naddunajskich wzorców kulturowych w neolicie północnej części Środkowej Europy), red. J. K. Kozłowski, Kraków, s. 147-149.

1998 The First Farmers. Najstarsi rolnicy, (w:) Pipeline of Archaeological Treasures. Gazociąg pełen skarbów archeologicznych, Poznań.

2002 Settlements of the Brześć Kujawski type on the Polish Lowlands, „Archeologické rozhledy”, t. LIV, s. 9-22.

2004 Kultury z cyklu ceramiki wstęgowej, (w:) Od dhugiego domu najstarszych rolników do dworu staropolskiego. Wyniki badań archeologicznych na trasach gazociągów Mogilno - Włocławek i Mogilno - Wydartowo, red. J. Bednarczyk, A. Kośko, Poznań, s. 195-212.

2008 Z badań nad neolityzacją Niżu Polski. Zagadnienie tzw. wpływów kultury rösseńskiej, (w:) Na pograniczu światów. Studia z pradziejów międzymorza bałtycko- pontyjskiego, red. J. Bednarczyk, J. Czebreszuk, P. Makarewicz, M. Szmyt, Poznań, s. 71-82.

Czerniak L., Kośko A.

1980a Badania sondażowe w Inowrocławiu - Mątwach, stan. 5, woj. Bydgoszcz (Przyczynek do badań nad chronologiczno-genetyczną interpretacją ugrupowań późnolendzielskich z ceramiką kłutą na Niżu Polski), „Sprawozdania Archeologiczne”, t. XXXIX, s. 29-53. 
1980b Zagadnienie efektywności poznawczej analizy chronologicznej ceramiki na podstawie cech technologicznych, „Archeologia Polski”, t. XXV, s. 247-279.

Czerniak L., Piontek J.

1980 Próba modelowego opisu form organizacji społecznej i gospodarczej ludności „,kultur wstęgowych” na podstawie analizy zespołów osadniczych typu Brześć Kujawski, „Archeologia Polski”, t. XXIV, z. 2, s. 335-358.

Domańska L.

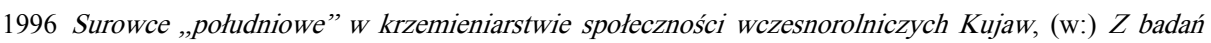
nad genezą regionalizmu społeczeństw Kujaw. Studia i materiały do dziejów Kujaw - Niżu Polski, red. A. Kośko, vol. 6, Poznań, s. 107-120.

Empacher A. B., Sęp B., Żukowska A., Żakowski W.

1977 Mały słownik matematyczny, Warszawa.

Gabałówna L.

1963 Ślady osadnictwa kultur z cyklu wstęgowych w Radziejowie Kujawskim, „Prace i Materiały Muzeum Archeologicznego i Etnograficznego w Łodzi”, Seria Archeologiczna, t. 9, s. 25-95.

1966 Ze studiów nad grupą brzesko-kujawską kultury lendzielskiej. Brześć Kujawski - stanowisko 4, „Acta Archaeologica Lodziensia”, t. 14.

Golachowski S., Kostrubiec B., Zagozdzon A.

1974 Metody badań geograficzno-osadniczych, Warszawa.

Grygiel R.

1986 The household luster as a fundamental social unit of the Lengyel Culture in the Polish Lowlands, „Prace i Materiały Muzeum Archeologicznego i Etnograficznego w Lodzi”, seria archeologiczna, t. 31, s. 43-334.

1996 Wkład kultury malickiej w powstanie i rozwój grupy brzesko-kujawskiej kultury lendzielskiej, (w:) Kultura malicka (Drugi etap adaptacji naddunajskich wzorców kulturowych w neolicie pólnocnej części środkowej Europy), red. J. K. Kozłowski, Kraków, s. 79-110.

2004 Neolit i początki epoki brązu w rejonie Brześcia Kujawskiego i Osłonek, t. I: Wczesny neolit, kultura ceramiki wstęgowej rytej, Łódź.

2008 Neolit i początki epoki brązu w rejonie Brześcia Kujawskiego i Osłonek, t. II, cz. 1-3: Środkowy neolit, grupa brzesko-kujawska kultury lendzielskiej, Łódź.

Ilkiewicz J.

2005 Wczesnoneolityczne narzędzia kamienne z Pobrzeża Koszalińskiego, „Folia Praehistorica Posnaniensia", t. XIII/XIV, s. 91-115.

Jankuhn H.

1983 Wprowadzenie do archeologii osadnictwa, Warszawa.

Jażdżewski K.

1938 Cmentarzyska kultury ceramiki wstęgowej i związane z nimi ślady osadnictwa w Brześciu Kujawskim, „Wiadomości Archeologiczne”, t. XV, s. 1-105.

Kietrzewska-Zalesiak M.

1976 Geografia osadnictwa, Warszawa.

Konopka M.

1984 Instrukcja ewidencji stanowisk archeologicznych metodą badań powierzchniowych (Archeologiczne Zdjęcie Polski), Warszawa.

Kostrzewski J., Chmielewski K., Jażdżewski K.

1965 Pradzieje Polski, Wrocław-Warszawa-Kraków.

Kozłowski J. K.

1966 Próba klasyfikacji materiałów zaliczanych do kultury lengyelskiej i nadcisańskiej w Polsce południowej, „Archeologia Polski”, t. XI, s. 7-25. 
1988 Z problematyki interregionalnych powiązań Kujaw w młodszej epoce kamienia, (w:) Kontakty pradziejowe społeczeństw Kujaw z innymi ludami Europy, red. A. Cofta-Broniewska, Inowrocław, s. $45-79$.

Kruk J.

1980 Gospodarka w Polsce południowo-wschodniej w V-III tysiącleciu p.n.e., Wrocław.

1981 Kilka uwag o znaczeniu poszukiwań powierzchniowych $w$ badaniach nad geografią osadnictwa pradziejowego, (w:) Zdjęcie Archeologiczne Polski, „Biblioteka Muzealnictwa i Ochrony Zabytków", seria B, t. LXVI, s. 115-120.

Marciniak A

2004 Mikrospołeczny wymiar pasterstwa i nomadyzmu i tafonomiczne podstawy ich identyfikacji W materiałach faunistycznych, (w:) Nomadyzm a pastoralizm w międzyrzeczu Wisły i Dniepru (neolit, eneolit, epoka brązu), red. A. Kośko, M. Szmyt, Poznań, s. 35-43.

2008 Interaction between hunter-gatherers and farmers in the Early and Middle Neolithic in the Polish part of the North European Plain, (w:) Time and Change. Archaeological and Anthropological Perspectives on the Long-Term in Hunter-Gatherer Societies, red. D. Papagianni, R. Layton, Oxford, s. $115-133$.

Paner H., Fudziński M., Goden K.

2004 Ratownicze badania archeologiczne w obrębie autostrady A1 na terenie województwa pomorskiego, (w:) Raport 2001-2002. Wstępne wyniki konserwatorskich badań archeologicznych w strefie budowy autostrad w Polsce za lata 2001-2002. Zeszyty Ośrodka Ochrony Dziedzictwa Archeologicznego, seria B: Materiały Archeologiczne, red. Z. Bukowski, Warszawa, s. 1-30.

Pavúk J.

2007 Zur Frage der Entstehung und Verbreitung der Lengyel-Kultur, (w:) The Lengyel, Polgár and related cultures in the Middle/Late Neolithic in Central Europe, red. J. K. Kozłowski, P. Raczky, Kraków, s. $11-28$.

Pearson G. W., Pilcher J. R., Baillier M. G. L., Corbett D. M., Qua F.

1986 High-precision $14 C$ measurement of Irish oaks to show the natural $14 C$ variation from AD 1840 to 5210 BC, ,Radiocarbon”, t. 28 (2B), s. 911-934.

Pelisiak A.

2003 Osadnictwo. Gospodarka. Społeczeństwo. Studia nad kulturą pucharów lejkowatych na Niżu Polskim, Rzeszów.

Pyzel J.

2006a Die Besiedlungsgeschichte der Bandkeramik in Kujawien, „Jahrbuch des Römisch-Germanischen Zentralmuseum Mainz", t. 53, z. 1, s. 1-59.

2006b Społeczności kultury ceramiki wstęgowej rytej na Kujawach, Warszawa, (maszynopis pracy doktorskiej w archiwum Instytutu Archeologii i Etnologii PAN w Warszawie).

Smoczyńska $€$.

1953 Kultura ceramiki wstęgowej w Wielkopolsce, „Fontes Praehistorici”, t. 3, s. 1-85.

Wiślański T

1969 Podstawy gospodarcze plemion neolitycznych w Polsce północno-zachodniej, Wrocław.

Witczak E.

2007 Osady kultury ceramiki wstęgowej rytej na w Chemiczkach, gm. Kruszwica stanowisko 10 (ET 47), Poznań (maszynopis pracy magisterskiej w archiwum Instytutu Prahistorii Uniwersytetu im. Adama Mickiewicza w Poznaniu).

Wojciechowski W.

1970 Zagadnienie chronologii relatywnej kultur młodszej epoki kamienia na Dolnym Śląsku na tle środkowoeuropejskiej systematyki neolitu, Wrocław. 
1976 Ze studiów nad ciągłością osadnictwa wstęgowego w południowych rejonach Dolnego Śląska, „Studia Archeologiczne”, t. IX, s. 4-56.

\section{Zápotocká M.}

1970 Die Stichbandkeramik in Böhmen und in Mitteleuropa, (w:) Die Anfänge des Neolithikums von bis Nordeuropa, Fundamenta, Reihe A, Bd. 3, Köln-Wien.

\section{THE LATE BAND POTTERY CULTURE COMMUNITIES IN THE CENTRAL KUJAVIA PLATEAU}

\section{Sum mary}

The paper presents results of two inter-related studies. The first comprises a microregional analysis restricted to three diagnostic sites (Chełmiczki 10, Karczyn 21/22, Olszewice 7). A systematic description of features and related artefacts from these sites paves the way to discussion on their function, chronology and topogenesis, making possible to define them as settlements. In case of Karczyn 21/22, the materials are dated to phases I and II of the Late Band Pottery Culture while the chronology of the other sites is linked to its phase III.

The second analytical strand focuses on the geography of settlement. It aimed to relate the three sites to the spatial and cultural network of this culture. On the micro- and macroregional scale, the analysis attempts to investigate the rules of settlement location in relation to: (1) basic geomorphologic units, and (2) local hydrography.

Future works on the 'Late Band' settlements need to address an interesting question of the relationships and dependencies between the Late Band Pottery culture and the cultural entities of the Middle and Late Neolithic (FBC, GAC).

One has also to mention another important aspect of geographical methods in archaeology, as applied to settlement studies. It is a part of the research tradition advocating scientific approach to the settlement geography in archaeology. The approach is characterized by a systematic use of maps, graphs, tables, statistics and mathematical models that make possible to significantly improve our knowledge of differences in the spatial arrangement of the phenomena under investigation. However, this model has some shortcomings as it leaves aside certain important cultural variables. A behavioural or humanistic approach to the geography of settlement, makes possible to address a complexity of human motivation and grasp a social dimension of space.

Translated by Piotr T. Żebrowski 